\title{
Caracterização da Comunidade Microbiana de Biofilme Anaeróbio em Presença de Bifenilas Policloradas
}

Dissertação apresentada à Escola de Engenharia de São Carlos da Universidade de São Paulo para obtenção do título de Mestre em Ciências, Programa de Engenharia Hidráulica e Saneamento.

Orientadora: Profa. Dra.Maria Bernadete A. Varesche

VERSÃO CORRIGIDA 
AUTORIZO A REPRODUÇÃO TOTAL OU PARCIAL DESTE TRABALHO, POR QUALQUER MEIO CONVENCIONAL OU ELETRÔNICO, PARA FINS DE ESTUDO E PESQUISA, DESDE QUE CITADA A FONTE. anaeróbio em presença de Bifenilas Policloradas. / Mara Rúbia de Lima e Silva; orientadora Maria Bernadete A. Varesche. São Carlos, 2012.

Dissertação (Mestrado) - Programa de Pós-Graduação e Área de Concentração em Hidráulica e Saneamento -Escola de Engenharia de São Carlos da Universidade de São Paulo, 2012.

1. PCB. 2. Bactérias redutoras de ferro. 3. NMP. 4. Arquéias Metanogênicas. 5. Chloroflexi. I. Título. 
Candidata: Bacharel MARA RÚBIA DE LIMA E SILVA.

Título da dissertação: "Caracterização da comunidade microbiana de biofilme anaeróbico em presença de bifenilas policloradas".

Data da defesa: $27 / 04 / 2012$

\section{Comissão Julgadora:}

Prof $^{\mathrm{a}}$. Dr ${ }^{\mathrm{a}}$. Maria Bernadete Amâncio Varesche (Orientador)

(Escola de Engenharia de São Carlos/EESC)

Prof ${ }^{\mathrm{a}}$. Dr ${ }^{\mathrm{a}}$. Iolanda Cristina Silveira Duarte

(Universidade Federal de São Carlos/UFSCar)

Drin. Isabel Kimiko Sakamoto

(Escola de Engenharia de São Carlos/EESC)
Resultado:
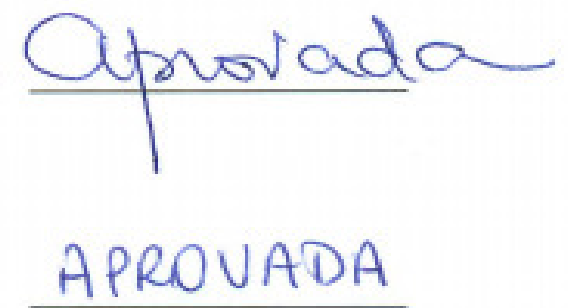

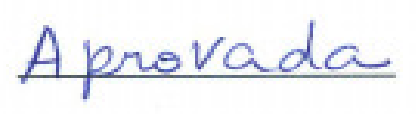

Coordenador do Programa de Pós-Graduação em Engenharia Hidráulica e Saneamento:

Prof. Titular Edson Cezar Wendland

Presidente da Comissão de Pós-Graduação:

Prof. Associado Paulo Cesar Lima Segantine 

“Com intelectualidade pura cria-se invejosos, com o coração cria-se amigos."

Chico Xavier 



\section{AGRADECIMENTOS}

A Profa. Dra. Maria Bernadete Varesche, minha orientadora, por acreditar em mim e estar sempre presente. Muito obrigada!

A Regiane Correa pela maternidade, grande ajuda e colaboração desde o início deste trabalho.

Aos Professores Marcelo Zaiat, Eugenio Foresti, Wiclef e Márcia Damianovick, pela simpatia e conversas agradáveis durante o cafezinho.

Ao apoio técnico, Eloisa Pozzi, Isabel Sakamoto e Maria Angela Adorno, muito obrigada por estarem sempre dispostas a ajudar nas etapas importntes de meu trabalho, com muita seriedade e competência.

Aos amigos Dljalma, Lívia Juliana, Fabrício, Edilincon e Filipe pelas críticas construtivas e pela amizade. Sem vocês minha vida em São Carlos seria muito séria!

Ao colega Tiago Palladino, pela constante ajuda e preciosas dicas durante meu trabalho.

A todos os amigos do LPB, que tive a satisfação de conciver dia-a-dia e que dividiram comigo o espaço nas bancadas, fazendo meus dias de trabalho mais agradáveis: Adriana, Adis, Eduardo Penteado, Lorena, Gustavo Mockaits, Guilherme, Theo Syrto, Tiago Martins, Tiago Palladino, Juliana Kawanishi, Fabricio, Bruna, Priscila, Pilar, Débora, Dago Okada, Djalma, Flavia, Filipe, Livia, Regiane Ratti, Carol Zampol, Daniel Lima, Sandra, Raphael Moura, Jorge Pantoja, Betão, Janja, Elô, Bel, Henrique Altero, Tais Hamamoto e Regiane Correa. 
Aos funcionários do SHS por estarem sempre prontos a ajudar, Pavi, Sá, Rose, Flávia, Fernanda e André.

Aos funcionários e técnicos do Campus 2, Silvana, Fernando, Juliana, Camilo e Edson, muito gentis e dispostos a ajudar.

A Escola de Engenharia de São Carlos (EESC/USP) pela oportunidade de realização do mestrado.

A Capes pela concessão da bolsa de mestrado e apoio financeiro. A todos meus amigos de coração, que mesmo distante torceram por mim:

Juliane Passeri, Gabriela Puccineli, Marinês, Tâninha, Sarinha, Suellen, e a todos os membros da 2006 BARRA 1 !

A toda minha família, minhas irmãs (de sangue e de consideração), cunhados, sobrinhos e sobrinhas, que estiveram sempre torcendo por mim e me apoiando.

A Elisa Uliana por sempre acreditar, torcer e me apoiar nesta etapa difícil, porém de completa realização.

A minha querida irmã Milena, que mesmo em todas nossas brigas, nunca deixou de me apoiar.

A minha querida mãe, que mesmo de tão longe, conseguiu me apoiar e me segurar. Amo-te mãe.

A meu querido pai, que sei se estivesse aqui estaria muito feliz com minha conquista 


\section{RESUMO}

SILVA, M. R. de L. Caracterização da comunidade microbiana de biofilme anaeróbio em presença de bifenilas policloradas. 2012. 107f. Dissertação (Mestrado) Escola de Engenharia de São Carlos, Universidade de São Paulo, 2012.

Bifenilas policloradas (PCBs) são compostos de difícil degradação presentes na composição de ascarel, muito utilizado como fluidos dielétricos e isolantes. Neste contexto, a presente pesquisa teve como objetivo avaliar a diversidade de microrganismos em biofilmes de reatores anaeróbios na presença de PCB empregando Métodos de Microbiologia de Anaeróbios Estritos e de Biologia Molecular. Em reator anaeróbio horizontal de leito fixo (RAHLF), alimentado com etanol, formiato, Triton X-100 $(0,1 \%)$ e ascarel $(1 \mathrm{~mL} / \mathrm{L})$, operado com tempo de detenção hidráulica (TDH) de 24 horas, foi retirado a comunidade microbiana do biofilme da espuma de poliuretano. Os grupos microbianos encontrados por meio da clonagem e sequenciamento do gene RNAr 16S para o domínio Bacteria foram relacionados aos filos Thermogae, Proteobacteria (Brachymonas petroleovorans, 100\% de similaridade e Methylobacillus, 98\% de similaridade), Firmicutes (Clostridium, $97 \%$ de similaridade, Syntrophomonas, $100 \%$ de similaridade e Sporomusa com 100\% de similaridade), Synegistetes (Synergistes, 98\% de similaridade), Spirochaetes (Leptonema illini, 98\% de similaridade), Aminanaerobia, Deferribacteres, Chlorobi, Chloroflexi e Armatimonadetes. Além disso, como nesse biofilme foram identificadas bactérias redutoras de ferro, procedeu-se a sua quantificação por meio da técnica de tubos múltiplos (NMP, Número Mais Provável) obtendo 5,26x $10^{12} \mathrm{NMP} / \mathrm{g}$ STV de bactérias redutoras de ferro. Ensaio em batelada foi realizado separadamente sob duas condições: (1) metanogênica e (2) ferro redutora. Em ambas as condições foram adicionadas aroclor 1260 (PCB). Os reatores, sob condição metanogênica, foram alimentados com meio de cultivo Angelidaki e substratos orgânicos (formiato e etanol), além de aroclor $1260(0,2 \mu \mathrm{g} / \mathrm{L})$. Para simular a condição redutora de ferro foi acrescido ao meio de cultura Angelidaki, EDTA férrico (1,86 g/L). A produção de metano, na presença de aroclor 1260 foi de $3,8 \times 10^{-4} \mathrm{mmol} \mathrm{CH}_{4} / \mathrm{g} \mathrm{STV}$. A presença de bactérias ferro redutoras foi confirmada indiretamente pela taxa média de redução férrica (90\%) nos reatores em batelada, após 60 dias de operação. Por meio de PCR/DGGE, elaborou-se um dendograma das amostras deste ensaio em batelada (metanogênico e redutor de ferro) comparativamente com as do reator RAHLF (biofilme presente na parede do reator e no material suporte). Os reatores em batelada apresentaram similaridade entre si de $79 \%$ e $92 \%$ para os domínios Bacteria e Archaea, respectivamente. As amostras do reator RAHLF foram 80\% (Bacteria) e 96\% (Archaea) similares. A existência de bactérias degradadoras de PCB, bem como, bactérias redutoras de ferro no biofilme anaeróbio contribuiu com informações sobre o consórcio microbiano e sua diversidade.

Palavras-chave: PCB, bactérias redutoras de ferro, NMP, Arquéias Metanogênicas, Chloroflexi. 


\begin{abstract}
SILVA, M. R. de L. e Characterization of the microbial community in the presence of polychlorinated biphenyls. 2012.107f. Dissertação (Mestrado) - Escola de Engenharia de São Carlos, Universidade de São Paulo, 2011.

Polychlorinated biphenyls (PCBs) are compounds of difficult degradation, a component of askarel, which were used widely as coolants and lubricants. Hence, this study evaluated the diversity of microorganisms in the presence of PCBs in anaerobic reactors. For such, methods as Strict Anaerobic Microbiology and Molecular Biology were employed. The microbial community of the biofilm, developed in a fixed horizontal bed anaerobic reactor (RAHLF), was studied using the technique of cloning and sequencing of RNAr 16S gene for the Bacteria domain. The reactor had immobilized cells in polyurethane foam with ethanol and formate as a carbon source, Triton X-100 (0.1\%) and polychlorinated biphenyls $(1 \mathrm{~mL} / \mathrm{L})$, and operated with 24 hours HRT. The microbial groups found in this biofilm were related to phyla Thermogae, Proteobacteria (Brachymonas petroleovorans, $100 \%$ similarity and Methylobacillus, 98\% similarity), Firmicutes (Clostridium, 97\% similarity Syntrophomonas, and 100\% similarity with Sporomusa 100\% similarity), Synegistetes (Synergistes, 98\% similarity), Spirochaetes (Leptonema Illini, 98\% similarity), Aminanaerobia, Deferribacteres, Chlorobi, Chloroflexi and Armatimonadetes. Furthermore, as bacteria that reduce iron were found, we proceeded the quantification by the multiple tube method (MPN) for this group, obtaining $5.26 \times 10^{12}$ MPN/ g STV of iron-reducing bacteria. The batch reactors evaluated the growth of microorganisms in two condictions: (1) methanogenic e (2) iron reduction, both had the presence of PCBs (Aroclor 1260). The reactor, under methanogenic condition, was fed with synthetic substrate Angelidaki, ethanol and formate, used as carbon source, and aroclor $1260(0.2 \mu \mathrm{g} / \mathrm{L})$. To simulate the condition of iron reducing, the same synthetic substrate was supplemented with ferric EDTA $(1.86 \mathrm{~g} / \mathrm{L})$. The production of methane in the presence of aroclor 1260, was $3.8 \times 10^{-4} \mathrm{mmol} \mathrm{CH}_{4} / \mathrm{g} \mathrm{STV}$. The presence of iron reducing bacteria, after 60 days, was confirmed indirectly by the average rate of iron ferric reduction $(90 \%)$. Filogenetics analysis (PCR/DGGE) compared the samples of this batch reactor methanogenic and reduction of iron ferric -, with the samples of RAHLF - the biofilm in the reactor wall and the support material. The two condictions in batch reactors showed similarity of 79\% and 92\% respectively for the Bacteria and Archaea domain. Therefore, both samples of RAHLF showed $80 \%$ (Bacteria) and 96\% (Archaea) of similarity. In other words, more similarity were presented due configuration of the reactor as well as the type of PCB added. As a result, the existence of PCBs degrading bacteria and iron-reducing bacteria in anaerobic biofilm, provided informations about the microbial consortium and its diversity in the presence of PCB.
\end{abstract}

Keywords: PCB, iron-reducing bacteria, MPN, methanogenic archaea, Chloroflexi. 


\section{LISTA DE FIGURAS}

Figura 3-1. (a) Estruturas da bifenila; (b) PCB (2,2',3,4,4',5'-hexaclorobifenila) 14

Figura 4-1. Reator anaeróbio horizontal de leito fixo (RAHLF) 26

Figura 4-2. Amostras retiradas do RAHLF para a comparação da comunidade bacteriana, a) biofilme aderido na parede do RAHLF; b) biomassa imobilizada em espuma de poliuretano do RAHLF. 27

Figura 4-3. Fluxograma experimental empregado no trabalho. 28

Figura 4-4. Fluxograma das etapas do ensaio em batelada 31

Figura 4-5. Fluxograma das etapas do método de extração líquido/líquido de PCB 37

Figura 4-6. Esquema de distribuição da amostra nos frascos de diluição e quantificação por NMP_ 42

Figura 4-7. Sequencia de passos da retirada das amostras do reator até o sequenciamento 46

Figura 4-8. Fluxograma experimental da análise filogenética da comunidade microbiana 47

Figura 5-1. Dendograma baseado no coeficiente de correlação de Pearson, a partir dos padrões de bandas do DGGE com set de primer para o Domínio Bacteria (primers 968F-GC e 1400R) da biomassa aderida ao material suporte, biofilme aderido à parede do reator e inóculo. 52

Figura 5-2. Proporção dos grupos filogenéticos do biofilme aderido na parede do RAHLF 53

Figura 5-3. Árvore Filogenética de consenso dos clones obtidos a partir da amostra do biofilme do RAHLF para Domínio Bacteria baseado na análise comparativa da sequência do gene RNAr 16S calculado de acordo com o método Neighbor-joining 46

Figura 5-4. Frasco de contagem de NMP para bactérias redutoras de ferro: (a) tubos negativos; (b) tubos positivos

Figura 5-5. Produção média de metano em função do tempo ajustada com a função de Boltzman.

Figura 5-7. Morfologias observadas em microscópio óptico (1000X): (a) Morfologia característica de Metahnosarcina (b) Filamentos sem grânulos característicos de Methanosaeta (c) Arranjo em forma de digital característico de bacilos. 75 
Figura 5-8. Morfologias observadas em microscópio óptico (1000X) da condição redutora de ferro: (a) Bacilos, (b) Filamentos com grânulos que podem representar o armaenamento de ferro dentro da célula.

Figura 5-9. Dendograma com primers para o Domínio Bacteria, correlação de Pearson. RB= biofilme

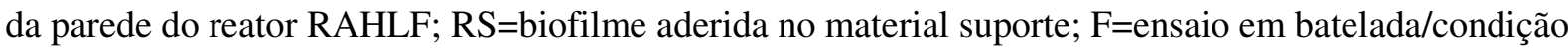
redutora de ferro; $M=e n s a i o$ em batelada/condição metanogênica; i=inóculo. 77

Figura 5-10. Dendograma com primers para o Domínio Archaea, correlação de Pearson. RB= biofilme da parede do reator RAHLF; RS=biofilme aderida no material suporte; F=ensaio em batelada/condição redutora de ferro; $M=$ =nsaio em batelada/condição metanogênica; i=inóculo. 78

Figura 8-1. Cromatograma das áreas em função do tempo de retenção do aroclor 1260. 104

Figura 8-2. Cromatograma das áreas em função do tempo de retenção do reator Branco - sem biomassa com meio Angelidaki e aroclor 1260. 104

Figura 8-3. Cromatograma das áreas em função do tempo de retenção do controle em condição metanogênica (M0), na presença de meio ANgelidaki e Aroclor 1260 e biomassa inativada. 104

Figura 8-4. Cromatograma das áreas em função do tempo de retenção do reator em condição metanogênica (M1), na presença de meio Angelidaki e Aroclor 1260 e biomassa. 105

Figura 8-5. Cromatograma das áreas em função do tempo de retenção do reator em condição metanogênica (M2), na presença de meio Angelidaki e Aroclor 1260 e biomassa. 105

Figura 8-6. Cromatograma das áreas em função do tempo de retenção do reator em condição metanogênica (M3), na presença de meio Angelidaki e Aroclor 1260 e biomassa. 105

Figura 8-7. Cromatograma das áreas em função do tempo de retenção do controle em condição redutora de ferro (BRF0), na presença de meio Angelidaki e Aroclor 1260 e biomassa inativada. _ 106 Figura 8-8. Cromatograma das áreas em função do tempo de retenção do reator em condição redutora de ferro (BRF1), na presença de meio Angelidaki e Aroclor 1260 e biomassa. 106 Figura 8-9. Cromatograma das áreas em função do tempo de retenção do reator em condição redutora de ferro (BRF2), na presença de meio Angelidaki e Aroclor 1260 e biomassa. 106 Figura 8-10. Cromatograma das áreas em função do tempo de retenção do reator em condição redutora de ferro (BRF3), na presença de meio Angelidaki e Aroclor 1260 e biomassa. 107 


\section{LISTA DE TABELAS}

Tabela 4-1.Composição do Meio Angelidaki 30

Tabela 4-2. Composição do meio de cultura para a comparação dos reatores metanogênicos e ferro redutores. 32

Tabela 4-4. Condições cromatográficas para amostra injetada em cromatógrafo gasoso HP 5890 série II para análise de PCBs 37

Tabela 4-5. Solução estoque 1 40

Tabela 4-6. Solução estoque 2 40

Tabela 4-7. Composição da água de diluição 41

Tabela 4-8. Primers para a amplificação da região $16 \mathrm{~S}$ do domínio Bacteria. 44

Tabela 4-9. Programação do Termociclador para os primers do domínio Bacteria 45

Tabela 4-10. Primers utilizados no PCR/DGGE 47

Tabela 4-11. Programação da reação de PCR para amplificação do RNAr 16S 48

Tabela 5-1. Identificação dos clones do biofilme amarelado para o Domínio Bacteria 55

Tabela 5-2. Concentração de ferro obtido do ensaio em batelada para os reatores BRF1, BRF2 e BRF3 71

Tabela 5-3. Ácidos orgânicos voláteis nos reatores em batelada. 73 


\section{LISTA DE ABREVIATURAS E SIGLAS}

ABNT

ANOVA

ATP

BLAST

BTEX

$\mathrm{CCDM}$

CG-EM

CLAE/UV

CNTP

CONAMA

DGGE

DMSO

DNA

DNTPs

DQO

ECD

EDS
Associação Brasileira de Normas Técnicas.

Análise de variância.

Trifosfato de adenosina.

Ferramenta de busca de homologia por alinhamento local.

Benzeno, tolueno, etilbenzeno e xileno.

Centro de Caracterização e Desenvolvimento de Materiais.

Cromatografia gasosa acoplada a espectrofotômetro de massa.

Cromatografia Líquida de Alta Eficiência com Detector de Ultravioleta.

Condições normais de temperatura e pressão.

Conselho Nacional de Meio Ambiente.

Eletroforese em gel de gradiente desnaturante.

Dimetilsulfóxido.

Ácido desoxirribonucleico.

Desoxirribonucleotideo Fosfatados

Demanda química de oxigênio.

Detector de captura de elétrons.

Espectômetro de dispersão de energia 
GTA Glutaraldeído.

IUPAC União Internacional de Química Pura e Aplicada.

LCE Laboratório de Caracterizaçao Estrutural/Departamento de Engenharia

MEV Microscopia eletrônica de varredura.

NBR

Norma brasileira.

NCBI

National Center for Biotechnology Information.

OCN

Octacloronaftaleno.

OTU

Unidades taxonômicas operacionais.

PAH Hidrocarbonetos aromáticos policíclicos.

PBS

Tampão Fosfato Salino

PCB

Bifenilas policloradas.

PCP

Pentaclorofenol.

PCR

Reação em cadeia da polimerase.

POP

Poluentes orgânicos persistentes.

RAHLF

Reator anaeróbio horizontal de leito fixo.

RNAr

Ácido Ribonucléico ribossômico.

SDS

Dodecilsulfato de sódio.

Sólidos totais. 
Sólidos totais fixos.

STV

Sólidos totais voláteis.

TAE

Tampão Tris-Acetato-EDTA

TCB

Triclorobenzeno.

$\mathrm{TDH}$

Tempo de detenção hidráulica.

UASB

Reator anaeróbio de manta de lodo ascendente. 


\section{ÍNDICE}

RESUMO

ABSTRACT

iii

LISTA DE FIGURAS

$\boldsymbol{v}$

LISTA DE TABELAS vii

LISTA DE ABREVIATURAS E SIGLAS ix

$\begin{array}{lll}1 & \text { Introdução } & 06\end{array}$

2 Objetivos $\quad 10$

$\begin{array}{ll}\text { 3.1. Objetivo Geral } & 10\end{array}$

$\begin{array}{ll}\text { 3.2. Objetivos Específicos } & 10\end{array}$

$3 \quad$ Revisão Bibliográfica 14

$\begin{array}{ll}3.1 \text { Histórico } & 15\end{array}$

$\begin{array}{ll}\text { 3.2 Degradação do PCB } & 17\end{array}$

$\begin{array}{ll}3.3 \text { Biodegradação Anaeróbia } & 19\end{array}$

$\begin{array}{lr}3.4 \text { Considerações finais } & 21\end{array}$

$4 \quad$ Material e Métodos 26

4.1 Inóculo $\quad 29$

$\begin{array}{lr}4.2 \text { РCB } & 29\end{array}$

4.3 Composição do substrato sintético 29

$\begin{array}{ll}\text { 4.4 Reator em batelada } & 31\end{array}$

$\begin{array}{lll}\text { 4.4.1 } & \text { Analises Fisico-químicas e cromatográficas } & 33\end{array}$

$\begin{array}{lll}\text { 4.4.2 } & \text { Potencial metanogênico } & 38\end{array}$ 
4.5.1 Número Mais Provável (NMP) $\quad 39$

4.5.2 Microscopia óptica e de fluorescência 43

$\begin{array}{lll}\text { 4.5.3 Análises filogenéticas } & 43\end{array}$

$5 \quad$ Resultados e Discussão

5.1 - 1a etapa - Caracterização da biomassa presente no RAHLF 52

5.1.1 Caracterização filogenética $\quad 52$

$\begin{array}{lll}\text { 5.1.2 } & \text { Técnica dos tubos múltiplos } & 66\end{array}$

$\begin{array}{ll}5.2 \text { - 2a etapa - Reator em Batelada } & 68\end{array}$

$\begin{array}{lll}\text { 5.2.1 } & \text { Análise de PCB }\end{array}$

$\begin{array}{lll}\text { 5.2.2 } & \text { Análise de Ácidos Orgânicos Voláteis } & 73\end{array}$

$\begin{array}{lll}\text { 5.2.3 Exames Microscópicos } & 75\end{array}$

5.2.4 Eletroforese Em Gel Com Gradiente Desnaturante 77

$\begin{array}{llr}6 & \text { Conclusões } & 84\end{array}$

$7 \quad$ Sugestões Para Trabalhos Futuros $\quad 88$

$8 \quad$ Referência Bibliográfica 90

$\begin{array}{lll}\text { 9 } & \text { Anexo } & 104\end{array}$ 
“Estude a sí mesmo, observando que o auto-conhecimento traz humildade e sem humildade é impossível ser feliz."

Chico Xavier 


\section{INTRODUÇÃO}

Composto xenobiótico é uma denominação genérica dada às substâncias biologicamente estranhas a um organismo e que afetam de alguma forma o seu comportamento (ORMOND, 2006). Neste contexto, esses compostos se tornam potencialmente tóxicos, não tendo somente efeitos imediatos, mas também que se instalam em longo prazo e de forma assintomática. Dentre os xenobióticos estão incluídos os compostos alifáticos e aromáticos clorados, do qual fazem parte as bifenilas policloradas (PCBs). Este gupo (bifenilas policloradas) contém 209 congêneres possíveis, sendo que 130 destes estão presentes nas misturas comerciais, encontradas em instalações industriais e comerciais com os seguintes nomes comerciais: Aroclor, Fenoclor, Phenclor e Ascarel entre outros (ABRAMOWICZ, 1990; BORJA et al., 2005; TIEDJE et al., 1993).

O estudo denominado "Sistema Estuarino de Santos e São Vicente" elaborado pela CETESB (2001) comprovou a contaminação do sedimento do estuário de Santos em alguns pontos de amostragem, bem como em mariscos, siris, caranguejos e ostras. Verificou-se que houve acumulação de PCBs em alguns organismos coletados no estuário, especialmente aqueles que são sésseis e filtradores (ostras e mexilhões), ocorrendo alguns valores acima do critério para consumo humano. Por exemplo, nos mexilhões foi detectado 42,01 $\mu \mathrm{g} / \mathrm{g}$ de PCB, enquanto o limite estabelecido é de $1,4 \times 10^{-4} \mu \mathrm{g} / \mathrm{g}$ (U.S. Environmental Protection Agency U.S. EPA) representando, portanto, perigo latente à saúde pública (RELATÓRIO DA CETESB, 2001).

A biodegradação de PCB é uma tecnologia relativamente nova e se tornou o foco de extensivas pesquisas nas últimas décadas. Consequentemente, o conhecimento dos mecanismos de dissipação destes compostos em ambiente natural foi intensamente aprofundado, e muitas possibilidades de biodegradação foram desenvolvidas, bem como biorreatores (ABRAMOVICK, 1990). Neste contexto, Correa (2011) avaliou a remoção de 
ascarel em reator anaeróbio horizontal de leito fixo (RAHLF) com biomassa imobilizada em espuma de poliuretano. A autora obteve remoção de até $90 \%$ de matéria orgânica (DQO), para concentração afluente de $1270 \mathrm{mg} / \mathrm{L}$, na presença de ascarel $(1 \mathrm{~mL} / \mathrm{L})$, óleo que contêm PCB em sua formulação

Este autor (Op. cit.) evidenciou também que bactérias redutoras de ferro estiveram presentes no RAHLF. Tal estudo revelou a presença de microrganismos capazes de utilizar ferro como aceptor final de elétrons, mais precisamente ferro trivalente. Lovley e Baedecker et al. (1989) indicaram que essas bactérias são capazes de oxidar benzoato, tolueno e $p$-cresol com $\mathrm{Fe}(\mathrm{III})$ como único aceptor final de elétrons, indicando possível participação destes microrganismos na degradação de compostos aromáticos, como o PCB.

Diante do exposto, o presente trabalho investigou a comunidade microbiana presente em biofilme anaeróbio na presença de PCB por meio de técnicas tradicionais de microbiologia de Anaeróbios e de Biologia Molecular. Especificamente nessa pesquisa, foi realizada a identificação por meio da clonagem e seque nciamento do gene RNAr 16S para Domínio Bacteria do biofilme amarelado que se desenvolveu na espuma de poliuretano usada como material suporte no RAHLF em presença de ascarel (1mL/L). Averigou-se também, por meio de ensaio em reatores em batelada, o cresci mento de bactérias redutoras de ferro e arquéias metanogênicas na presença de PCB $(0,5 \mathrm{~mL} / \mathrm{L}$ de aroclor 1260$)$, além da análise da diversidade por meio de PCR/DGGE do Domínio Bacteria e Archaea. Mediante tais inquirições, este trabalho visou ainda contribuir para um maior entendimento da diversidade microbiana em presença de $\mathrm{PCB}$, incrementando a possibilidade de estudos mais ab rangentes pertinentes a este composto 
“A gente deve lutar contra o comodismo e a ociosidade caso contrário, vamos retornar ao Mundo Espiritual com enorme sensação de vazio... Dizem que eu tenho feito muito, mas, para mim, não fiz um décimo do que deveria ter feito...” 


\section{OBJETIVOS}

\subsection{Objetivo Geral}

O principal objetivo deste trabalho foi caracterizar a comunidade microbiana na presença de PCB presente em biofilmes de reatores anaeróbios com material suporte.

\subsection{Objetivos Específicos}

- Caracterizar a comunidade microbiana presente no RAHLF, por meio de análise de sequenciamento,

- Quantificar a comunidade de bactérias ferro redutora presente no biofilme do RAHLF,

- Avaliar a presença de bactérias redutoras de ferro na presença de aroclor 1260 em reatores em batelada,

- Avaliar o potencial metanogênico na presença de aroclor 1260 em reatores em batelada,

- Analisar a diversidade de bactérias e arquéias metanogênicas nos reatores em batelada por meio da técnica de PCR/DGGE. 
"A vida, como a fizeres, estará, contigo em qualquer parte."

Chico Xavier 


\section{REVISÃO BIBLIOGRÁFICA}

As bifenilas policloradas, ou PCBs, são moléculas orgânicas estáveis, com baixa flamabilidade, alta temperatura de vaporização, baixo grau de reatividade, alta resistência elétrica e boa propriedade isolante. Estas características levaram ao seu uso em larga escala em transformadores e capacitores como fluidos dielétricos e isolantes instalados em área onde os riscos de incêndio e explosão deveriam ser minimizados, como em sub-estações elétricas localizadas no interior de prédios, veículos como trens e navios ou em locais com trânsito frequente de pessoas, além de outros empregos na indústria (ABRAMOWICZ, 1990; BORJA et at., 2005; PENTEADO e VAZ, 2001; TIEDJE et al., 1993).

A síntese do PCB tem sua origem no processo de refino do petróleo e consequente formação de benzeno, composto químico que dá origem ao PCB. Após a extração e purificação do benzeno, a bifenila é produzida (BAIRD, 2002). Bifenilas policloradas são produzidas pela inserção direta de cloro no bifenil com a presença de cloreto férrico como catalisador (HUTZINGER et al., 1974). A molécula de PCB é formada por dois anéis de seis carbonos, contendo de 1 a 10 moléculas de cloro ( Figura 3-1). São produzidas 209 diferentes combinações de acordo com a posição e quantidade de átomos de cloro inserido nos anéis. Estes isômeros e homólogos são comumente denominados de congêneres (ABRAMOVICK, 1990).

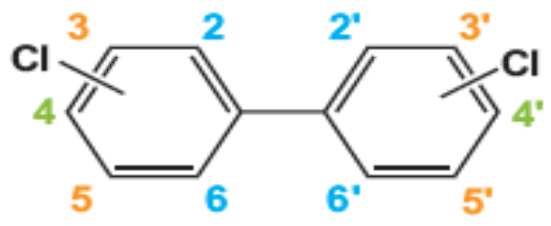

(a)

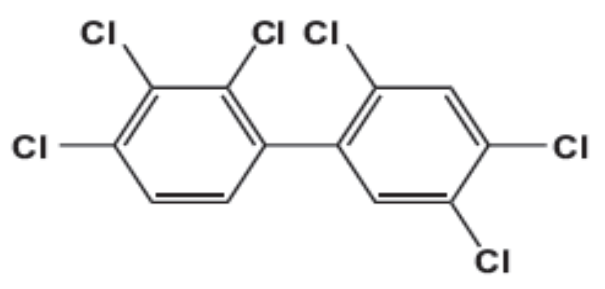

(b)

Figura 3-1. (a) Estruturas da bifenila; (b) PCB (2,2',3,4,4',5'-hexaclorobifenila)

Fonte: adaptado de Bedard (2008) 
Tendo em vista que as misturas de bifenilas policloradas obtidas comercialmente possuíam alta viscosidade, houve a necessidade de misturar o PCB com solventes benzoclorados com o objetivo de conferir à mistura uma viscosidade conveniente para que atuasse como agente dissipador de calor dentro dos equipamentos elétricos. Essa mistura de PCB e solvente organoclorado ficou conhecida no Brasil como ascarel e resultou em uma mistura de hidrocarbonetos derivados de petróleo, constituído por mistura de 50 a $70 \%$ de PCBs e de 30 a 50\% de TCBs (triclorobenzenos) ( ABNT, 1994 e 1997; ELETROPAULO, 1994; KINNER et al. , 1993).

\subsection{Histórico}

O PCB foi primeiramente sintetizado na Alemanha no final do século XIX e começou a ser produzido em escala mundial pela Monsanto em 1929. A sua produção foi crescente até meados de 1970 (HUTZINGER et al., 1976). A produção acumulada mundial foi estimada em 1.200.000 toneladas, dentre os quais $4 \%$ foram detectados no ambiente, sendo que o restante ainda encontra-se em uso ou armazenado (PENTEADO e VAZ, 2001). No Brasil, calcula-se que existam cerca de 200 mil toneladas de ascarel acumulada e dentre os quais, apenas 1.500 a 2.000 toneladas, ou seja, cerca de $1 \%$, são tratados por ano (PENTEADO e VAZ, 2001).

Os PCBs estão listados pela EPA como prioridade entre os poluentes orgânicos (FAGERVOLD, 2007). Mesmo com o término da produção de PCBs, em meados de 1970, em muitos países a contaminação do ambiente persiste, principalmente pela sua capacidade de bioacumulação e difícil remoção do cloro, o qual torna esses compostos tóxicos (LEISTER e BAKER, 1994; KO e BAKER, 2004). Em 1981, a fabricação e comercialização dos PCBs foram proibidas no Brasil. Entretanto, inúmeros transformadores que contem Ascarel continuam em uso e estes equipamentos quando substituídos podem se transformar em possíveis fontes de contaminação do meio ambiente. 
A difícil degradação das bifenilas policloradas se deve às seguintes características: (1) capacidade de bioconcentração (aumento imediato da densidade de um poluente assim que passa do meio aquoso para um organismo aquático) e (2) bioacumulação ou biomagnificação (acumulação do poluente ao longo da cadeia trófica a partir da alimentação). Em função da ocorrência da deposição e acumulação do PCB no ambiente existe uma proeminente preocupação dos órgãos de controle em relação aos possíveis riscos ambientais e para a saúde humana (SAFE, 1994). Os efeitos do PCB na saúde humana foram primeiramente documentados em 1968, em Yusho, Japão. Neste ano, milhares de indivíduos foram contaminados ao consumirem óleo de arroz contaminado com PCB. Os sintomas relatados foram relacionados com dermatites, hiperpigmentação da pele, danos no fígado, tireóide e mais seriamente no sistema nervoso periférico (ATSDR, 2000).

A partir dessa premissa, no Brasil a Instrução Normativa SEMA/STC/CRS N. 1 de 10 de junho de 1983 disciplina as condições a serem observadas no manuseio, armazenamento e transporte de bifenilas policloradas e ou resíduos contaminados com tais compostos. A Resolução CONAMA 19, de 29 de setembro de 1994 autoriza, excepcionalmente, a exportação de resíduos perigosos contendo bifenilas. Assim sendo, a eliminação ou manuseio não adequado podem caracterizar crime ambiental no país.

A Lei Estadual 12.288 de 22 de fevereiro de 2006 discorre sobre a eliminação controlada dos PCBs e dos seus resíduossobre a eliminação de transformadores, capacitores e demais equipamentos elétricos que contenham PCBs. De acordo com os critérios estabelecidos nesta lei os grupos que utilizam ou tenham equipamentos contendo PCBs, bem como óleos ou outros materiais contaminados por PCBs, ficam obrigadas a providenciar a sua eliminação progressiva até 2020. Devido a estas resoluções o uso de técnicas de degradação que não resulta na formação de compostos secundários tóxicos como possibilidade de eliminação de PCBs tem atraído muita atenção. 


\subsection{Degradação do PCB}

Desde 1977 a produção de PCB foi proibida em muitos países, porém, a sua entrada no ambiente e consequentemente, a contaminação ambiental ainda é muito significativa. As circunstâncias que favorecem a migração destes contaminantes dos processos industriais para o ambiente podem ser acidentes ou perda no manuseio de PCBs ou fluídos contendo o produto; vaporização de componentes contaminados com o composto; vazamento de transformadores, capacitadores etc, implicando em contaminação do ambiente em geral, inclusive da biota por mecanismos de bioconcentração e bioacumulação (PENTEADO e VAZ, 2001).

Um das alternativas para remoção desses resíduos é o tratamento físico, como por exemplo, a incineração de materiais contaminados com PCB. Todavia, a aplicação dessa técnica gera vários inconvenientes, tais como riscos de contaminação dos equipamentos a serem utilizados; necessidade de aterro Classe I para dispor as cinzas geradas; geração de efluentes líquidos e gasosos (dioxinas e furanos), que necessitam ser tratados antes do descarte final, com risco de contaminação ambiental (ATSDR, 2000).

Outra possibilidade de remoção desses compostos é por meio da degradação por bactérias. A biodegradação pode ocorrer por meio da mineralização ou participação em reações co-metabólicas (DOBBINS, 1995; MCELDOWNEYS et al., 1993). No processo de mineralização, os microrganismos utilizam o poluente como fonte de carbono e energia, resultando na redução do composto em seus elementos constituintes. No segundo processo, o microrganismo necessita de um co-substrato orgânico como fonte de carbono e energia. Nesseúltimo caso, a redução é conjunta, ou seja, do poluente e co-substrato. Para compostos biodegradáveis ocorre a mineralização, todavia para os outros compostos, reações incompletas são produzidas e, consequentemente formação de metabólitos intermediários 
mais tóxicos. Nessa última condição, um segundo consórcio microbiano é necessário para a utilização dos metabólitos produzidos (BORJA et al., 2004).

No caso de compostos aromáticos clorados, quanto maior a concentração de cloro maior é a energia necessária para sua remoção (DOBBINS, 1995). A inserção do cloro altera as características de ressonância dos compostos, bem como a densidade elétrica de sítios específicos (FURUKAWA, 1986). Além disso, a posição do cloro no anel aromático afeta sua remoção, já que essa posição modifica diretamente a afinidade das enzimas participadoras do processo de degradação (FURUKAWA, 1986; SYLVESTRE e SONDOSSI., 1994).

Quensen et al. (1988) verificarama remoção de cloro do Aroclor 1242 por microrganismos anaeróbios adaptados ao PCB e provenientes de sedimento do rio Hudson (EUA). Master et al. (2002) verificaram que o tratamento sequencial anaeróbio-aeróbio mostrou-se uma alternativa eficiente na remoção de PCBs de solo contaminado. Em condição anaeróbia ocorre preferencialmente reações redutoras, como substituição do cloro por hidrogênio (MCELDOWNEY, 1993). Todavia, na presença de oxigênio os compostos desclorados são então oxidados pelas bactérias aeróbias, resultando na mineralização dos PCBs (BOYLE et al., 1992).

Deste modo, o tratamento biológico é uma alternativa interessante, já que a descloração anaeróbia remove o cloro de PCBs altamente cloradas, que conjuntamente com a degradação aeróbia transforma alguns congêneres com baixo número de cloro (ABRAMOWICZ, 1993; MOHN e TIEDJE, 1992). Entretanto parâmetros como concentração do composto tóxico (DOBBINS, 1995), temperatura, pH, presença de compostos inibidores ou tóxicos, compostos que competem com o co-substrato, presença de aceptores de elétrons específicos e, ainda, interação entre as espécies de microrganismos determinam a velocidade de degradação sob determinada condição (BORJA et al., 2005). Sendo necessário um estudo mais detalhado destes parâmetros para que ocorra degradação efetiva do PCB. 


\subsection{Biodegradação Anaeróbia}

Wu et al. (2000) utilizaram sedimento estuarino para enriquecer cultura anaeróbia. Sob tal condição foi verificada a remoção de cloro, preferencialmente na posição para- e meta-. Em 2001, Rockne e Strand estudaram a biodegradação e mineralização de PAHs (hidrocarbonetos aromáticos policíclicos), tais como bifenilas policloradas (20 mM) em reator de leito fluidificado. A degradação dos hidrocarbonetos aromáticos bicíclicos e policíclicos foi dependente da concentração de nitrato. Portanto, os autores concluíram que esses compostos não foram recalcitrantes à biodegradação sob condição anóxica.

Grishchenkov et al. (2002) isolaram Citrobacter freunddi BS2211 em meio sintético suplementado com bifenila policlorada proveniente de cultura enriquecida do solo e resíduo industriais contaminados. Os autores verificaram que a linhagem foi capaz de degradar a bifenila policlorada sob condição anóxica, com redução de nitrato. Quando a concentração inicial de PCB foi igual a $150 \mathrm{mg} / \mathrm{mL}$ a $28^{\circ} \mathrm{C}$ para concentração celular de $10^{9}$ células $/ \mathrm{mL}$ a degradação foi de $26 \%$ a $28 \%$ em 3 dias. Para $250 \mathrm{mg} / \mathrm{mL}$ de bifenila policlorada com $10^{7}$ células/mL observou-se 17\% de degradação em 21 dias.

Wu et al. (2002) identificaram microrganismos cujo crescimento foi associado à descloração de bifenilas policloradas, com cloros nas posições orto- ou meta- dos dois lados em um anel benzeno ("doubly flanked chlorines"). As sequiências do RNAr 16S, obtidas da cultura enriquecida levaram à identificação de três unidades taxonômicas operacionais (OTUs 1, 2 e 3). A OTU 1 foi sempre detectada quando 2,3,4,5-cloro benzeno ou outros congêneres com dois cloros foram descloradas. As OTUs 2 e 3 foram detectadas na ausência de PCBs. As sequências parciais de OTUs 2 e 3 apresentaram 98,2\% de similaridade a Desulfovibrio caledoniensis. As bactérias redutoras de sulfato identificadas nas OTUs 2 e 3 não foram capazes de desclorar 2,3,4,5-CB, quando incubada em meio E-Cl contendo $10 \mathrm{mM}$ de formiato ou $10 \mathrm{mM}$ de lactato. Assim, a OTU 1 representou grupo de bactérias descloradoras 
em co-cultura com Desulfovibrio sp. A sequência da OTU 1 foi similar (89\%) à bactéria $o-17$, a qual foi capaz de desclorar orto-PCB. As arquéias metanogênicas não participaram da descloração de PCBs com dois cloros na mesma posição em um dos anéis do benzeno.

Fagervold et al. (2005) verificaram que espécies do grupo Chloroflexi são reconhecidamente capazes de degradar anaerobiamente as bifenilas policloradas por descloração redutiva. PCB $101\left(2,2^{\prime}, 4,5,5^{\prime}-\mathrm{CB}\right)$ foi desclorado redutivamente a PCB 49 $\left(2,2^{\prime}, 4,5^{\prime}-\mathrm{CB}\right)$, nas posições di-para-e meta-pelo filotipo DEH10, semelhante a Dehalococcoides. Este mesmo grupo foi eficiente para desclorar PCB 132 a PCB 91 (2,2',3',4,6'-CB), nas posições para-, di-orto- e meta-. No entanto, outro grupo designado SF1, mais estreitamente relacionado ao grupo $o-17 / \mathrm{DF}-1$ foi responsável pela subsequente descloração do PCB 91 a PCB 51 (2,2',4,6'-CB).

Destaca-se também que sob condição anaeróbia o Fe(III) é um aceptor de elétrons em potencial (BAEDECKER et al., 1979; CHAMP et al., 1979; LOVLEY e PHILLIPS, 1987; LOVLEY e GOODWIN, 1988), para a oxidação de compostos aromáticos (Lovley et al., 1989). Lovley e Lonergan (1990b) fizeram testes com sedimento e adição de tolueno. Sob tais condições, evidenciaram a oxidação total do benzoato em dióxido de carbono com a redução de Fe(III).

Lovley et al. (1989) isolaram bactérias redutoras de ferro (BRF), do grupo GS-15, estritamente anaeróbias, que não crescem sob condição fermentativa e podem utilizar acetato como aceptor de elétrons para a redução de Fe(III). Estas bactérias podem obter energia para o crescimento através da oxidação de inúmeros compostos aromáticos (benzoato, tolueno, $p$ cresol, fenol), com ferro, como aceptor de elétrons (LOVLEY e LONERGAN, 1990b, LOVLEY et al., 1989).

Exemplo do fundamental papel do Fe(III) na oxidação de contaminantes em águas subterrâneas foi observado no aquífero glacial em Bemidji, Minnesota (EUA). Este aquífero 
foi contaminado por vazamento de cerca de 1.700 .000 litros de óleo em 1979. A coluna de água que desenvolveu condição anaeróbia abaixo do corpo de óleo continha componentes hidrossolúveis, tais como, benzeno, tolueno, etilbenzeno, xileno e hidrocarbonetos aromáticos polinucleares (HULT e SURVEY, 1984). Os autores observaram degradação de benzeno e alquibenzeno em ambiente anaeróbio.

Estes autores (Op. cit.) verificaram em experimento (condição similar ao do ambiente formado) que a degradação de alquilbenzeno e benzeno ocorreu com o aumento da concentração de $\mathrm{Fe}(\mathrm{II})$ e $\mathrm{Mn}(\mathrm{II})$ no meio. Portanto, comprovou-se a degradação de hidrocarbonetos pela redução de ferro e manganês (BAEDECKER et al., 1993).

Roden et al. (2000) compararam a redução férrica em areia revestida por Fe (III), contendo $104 \pm 8 \mu \mathrm{mol} . \mathrm{g}^{-1}$ de peso seco, em reator de fluxo contínuo e em reator em batelada. Foram inoculadas células de Shewanella putrefaciens $\mathrm{CN} 32$ no meio reacional. A quantidade de $\mathrm{Fe}(\mathrm{II})$ dissolvido e acumulado na coluna do reator com seis meses de incubação correspondeu a 95,5 $\pm 3,7 \%$ do $\mathrm{Fe}(\mathrm{III})$ contido no meio. Este estudo comprovou a possibilidade da dissolução redutiva completa de Fe(III) na fase líquida sob condição de fluxo contínuo.

\subsection{Considerações finais}

Por meio de trabalhos apresentados anteriormente sobre as características do PCB, sua extensa produção e consumo mundial, seus efeitos biológicos, processos de remoção e degradação, nota-se que especial atenção deve ser dada ao seu destino.

Diversas são as pesquisas que visam desenvolver possibilidades tecnológicas para degradar PCBs presentes no ambiente, sejam por processos químicos, físicos ou biológicos. Para o melhor entendimento e aperfeiçoamento dos processos biológicos, ainda devem ser realizadas pesquisas acerca dos diversos fatores que interferem em sua degradação, tais como 
o processo empregado (por exemplo, configuração do reator), presença de determinados microrganismos identificados por metodologias de caracterização microbiana, produtos intermediários de sua degradação e possível inibição aos microrganismos, entre outros.

Além disso, a carência de aceptores de elétrons em condição anaeróbia é o principal fator limitante do crescimento microbiano. Consequentemente, qualquer microrganismo que possa utilizar um aceptor de elétrons abundante no meio, como o ferro, poderia ter uma vantagem em relação aos outros utilizadores de PCB em meio anaeróbio. Tal tecnologia, ainda, não foi estudada na remoção de $\mathrm{PCB}$ e tem se mostrado bastante eficiente no tratamento de águas residuárias para a remoção de outros compostos aromáticos.

Desse modo, com este trabalho pretendeu-se caracterizar a comunidade microbiana presente no biofilme proveniente de reator de leito fixo na presença de ascarel por meio de técnica de clonagem, além de comparar a diversidade entre o biofilme desenvolvido neste reator de leito fixo com 180 dias de operação com o que se desenvolveu nos reatores em batelada na presença de PCB com 60 dias de operação, por meio da técnica de PCR/DGGE. No ensaio em batelada estudou-se o crescimento da comunidade metanogênica capaz de crescer em meio contendo PCB, bem como de bactérias redutoras de ferro. 
“Embora nínguem possa voltar atrás e fazer um novo recomeço, qualquer um pode começar agora e fazer um novo fim." 


\section{MATERIAL E MÉTODOS}

Este projeto foi realizado com a finalidade de avaliar a comunidade microbiana presente no biofilme do reator anaeróbio horizontal de leito fixo (RAHLF) (Figura 4-1), bem como, avaliar a produção de metano e quantificar as bactérias redutoras de ferro em meio com substrato sintético e PCB. Para tanto, os experimentos foram executados em duas etapas.

Na primeira etapa (Figura 4-3), realizou-se investigação microbiológica de amostras retiradas da biomassa adaptada (Figura 4-2), com 180 dias de operação e TDH de 24 horas alimentado com ascarel ( $1 \mathrm{~mL} / \mathrm{L})$, em reator anaeróbio horizontal de leito fixo (RAHLF). Esse reator foi monitorado por Correa (2011) e fez parte do trabalho de tese dessa pesquisadora. $\mathrm{Na}$ análise comparativa da comunidade de bactérias foram avaliadas as seguintes amostras: 1) lodo granulado de UASB utilizado como inóculo do RAHLF; 2) biomassa imobilizada em espuma de poliuretano do RAHLF; 3) biofilme aderido na parede do RAHLF.

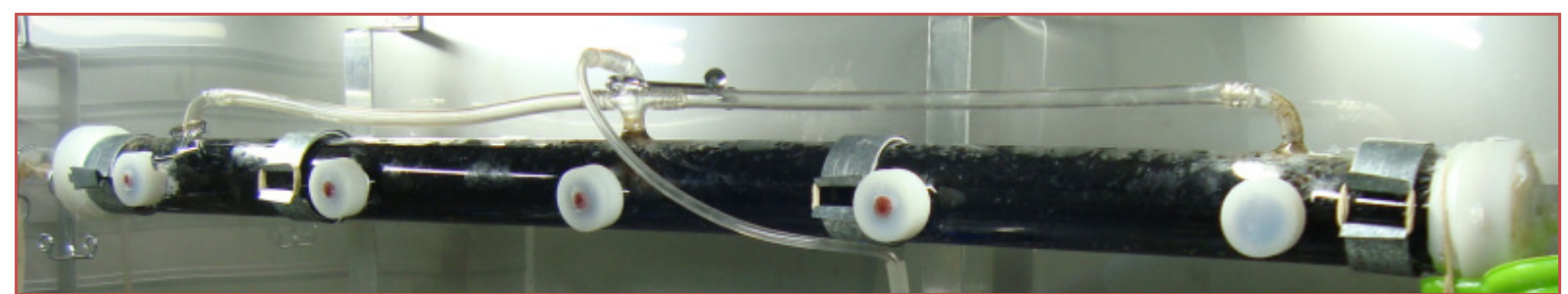

Figura 4-1. Reator anaeróbio horizontal de leito fixo (RAHLF)

Fonte: CORREA, (2011) 


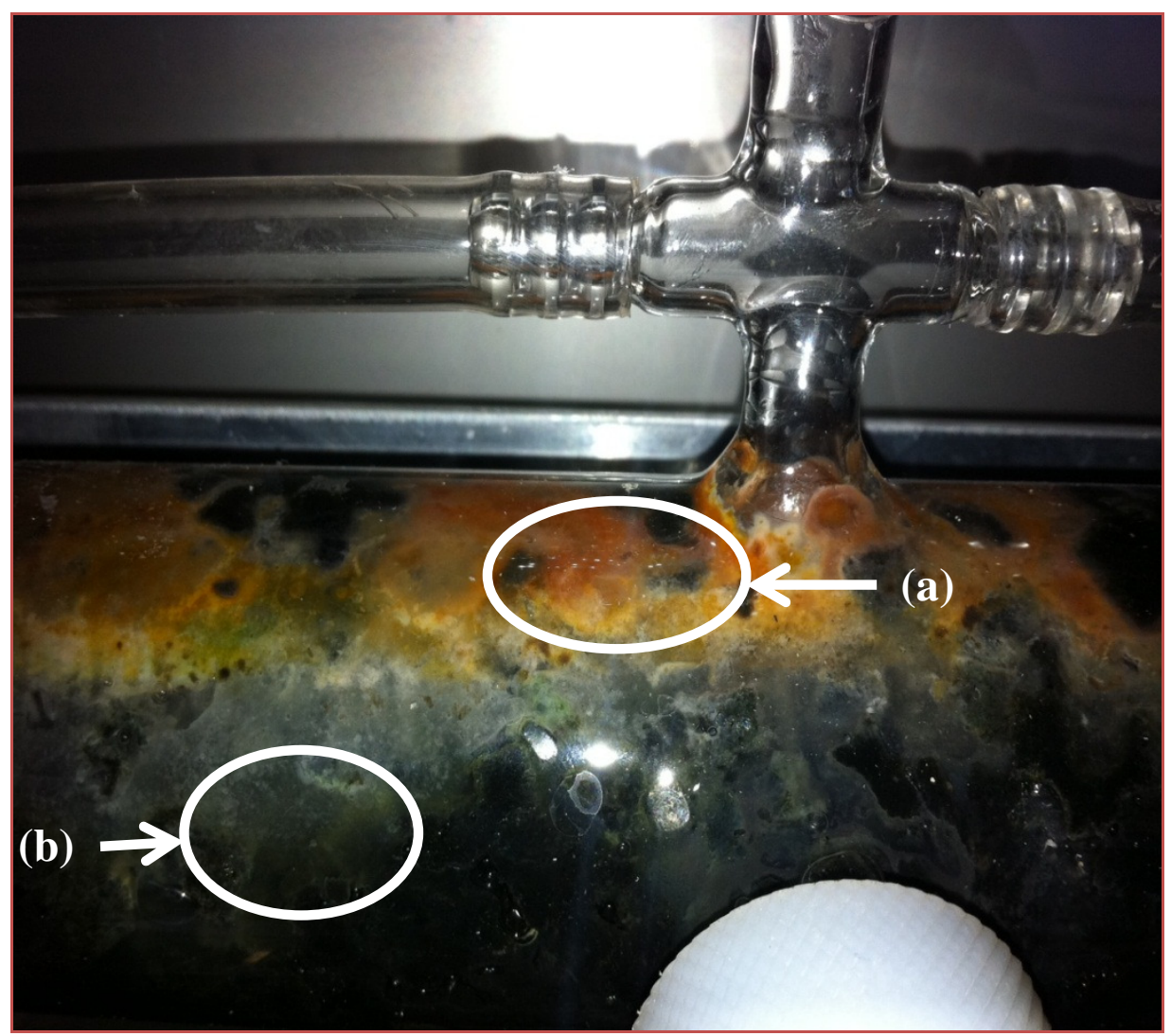

Figura 4-2. Amostras retiradas do RAHLF para a comparação da comunidade bacteriana, a) biofilme aderido na parede do RAHLF; b) biomassa imobilizada em espuma de poliuretano do RAHLF.

Na segunda etapa (Figura 4-3) foi realizado um ensaio em reatores em batelada, com a finalidade de avaliar diversidade microbiana apresentada em condições metanogênica e redutora de ferro em presença de PCB (aroclor 1260). Para tanto, nessa fase procedeu-se a avaliação da presença das bactérias redutoras de ferro (BRF) por meio da quantificação de ferro total comumente com as análises microscopia e de Biologia Molecular. A análise da diversidade microbiana foi realizada por meio da técnica de PCR/DGGE, e comparou as amostras deste ensaio em batelada com as amostras do reator RAHLF. O acompanhamento da produção de ácidos e álcool foi realizado bem como a avaliação do crescimento das arquéias metanogênicas através do monitoramento contínuo da produção de metano.

Os reatores em batelada foram incubados em estufa com agitação a $30^{\circ} \mathrm{C}$ durante 60 dias. Este tempo foi escolhido dentre aqueles já empregados para a degradação de PCB, 52 e 
100 dias, cuja degradação de aroclor 1242 foi entre 76 a 95\%, respectivamente (BAXTER et al., 1975).

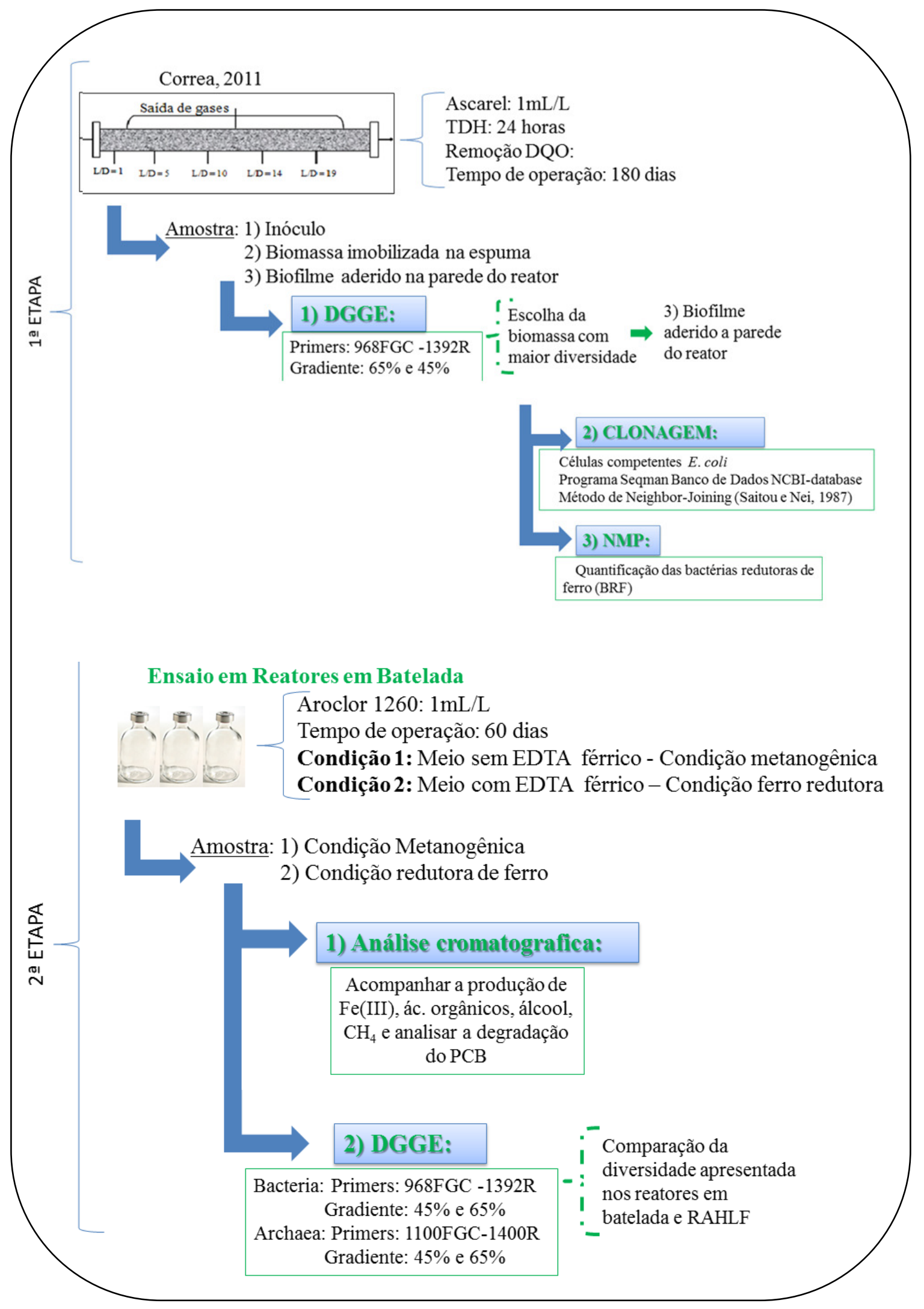

Figura 4-3. Fluxograma experimental empregado no trabalho. 


\subsection{Inóculo}

O inóculo utilizado no reator horizontal de leito fixo operado por Correa (2011) bem como os reatores do ensaio em batelada, foi proveniente de reator anaeróbio de manta de lodo e escoamento ascendente (UASB) usado no tratamento deresíduo de abatedouro de aves da Avícola Dakar (Tietê, SP). As amostras de biomassa para as análises de Biologia Molecular da primeira etapa, bem como para a inoculação e quantificação por tubos múltiplos (NMP) foram provenientes deste reator horizontal.

\subsection{PCB}

Nesse trabalho foi utilizado na alimentação do reator RAHLF (CORREA, 2011) ascarel, óleo de coloração amarelo citrino pouco viscoso e aparência límpida, proveniente da concessionária de fornecimento de energia elétrica BANDEIRANTES, situada na região de São José dos Campos (TR-01 ETD JAC - Ref ano 1977 fab. BB - tipo TD3LF - no. série P 8775 NGE - TRTCM 30031).Esse óleo contém mistura de bifenilas policloradas (PCBs) e triclorobenzenos (TCB).

Para a alimentação dos reatores em batelada, no ensaio de produção de metano e redução de ferro, além daquele usado no teste dos tubos múltiplos foi utilizado o padrão de PCB, aroclor 1260 da Sigma Aldrich.

\subsection{Composição do substrato sintético}

Em todas as etapasdo trabalho experimental, na alimentação do RAHLF (Correa, 2011), bem como nos reatores em batelada e na análise de número mais provável, foi utilizado o meio de cultivo Angelidaki (ANGELIDAKI et al., 1990) esolução de vitaminas (Wolin et al.,1963) (Tabela 4-1Tabela 4-1). Essas soluções foram preparadas de acordo com as técnicas para a manipulação de anaeróbios estritos como descritos por Vazoller (1995). 
Tabela 4-1.Composição do Meio Angelidaki

\begin{tabular}{|c|c|c|c|}
\hline Componente & $\begin{array}{l}\mathrm{C}_{\text {estoque }} \\
\text { (g/L) }\end{array}$ & $\begin{array}{l}\mathbf{V}^{* *} \\
(\mathrm{~mL})\end{array}$ & $\begin{array}{l}\mathrm{C}_{\text {solução }} \\
\text { (mg/L) }\end{array}$ \\
\hline \multicolumn{4}{|c|}{ 1. Meio basal (Angelidaki et al., 1990) } \\
\hline \multicolumn{4}{|c|}{ Solução A } \\
\hline $\mathrm{NH}_{4} \mathrm{Cl}$ & 100 & \multirow{4}{*}{10} & 1000 \\
\hline $\mathrm{NaCl}$ & 10 & & 100 \\
\hline $\mathrm{MgCl}_{2} \cdot 6 \mathrm{H}_{2} \mathrm{O}$ & 10 & & 100 \\
\hline $\mathrm{CaCl}_{2} \cdot 2 \mathrm{H}_{2} \mathrm{O}$ & 5 & & $\mathbf{5 0}$ \\
\hline \multicolumn{4}{|l|}{ Solução B } \\
\hline $\mathrm{K}_{2} \mathrm{HPO}_{4} \cdot 3 \mathrm{H}_{2} \mathrm{O}$ & 200 & 2 & 400 \\
\hline \multicolumn{4}{|l|}{ Solução C (metais traços e selenito) } \\
\hline $\mathrm{FeCl}_{2} \cdot 4 \mathrm{H}_{2} \mathrm{O}$ & 2 & \multirow{12}{*}{1} & 2 \\
\hline $\mathrm{H}_{3} \mathrm{BO}_{3}$ & 0,05 & & $\mathbf{0 , 0 5}$ \\
\hline $\mathrm{ZnCl}_{2}$ & 0,05 & & $\mathbf{0 , 0 5}$ \\
\hline $\mathrm{CuCl}_{2} \cdot 2 \mathrm{H}_{2} \mathrm{O}$ & 0,038 & & $\mathbf{0 , 0 3 8}$ \\
\hline $\mathrm{MnCl}_{2} \cdot 4 \mathrm{H}_{2} \mathrm{O}$ & 0,05 & & $\mathbf{0 , 0 5}$ \\
\hline$\left(\mathrm{NH}_{4}\right)_{6} \mathrm{Mo}_{7} \mathrm{O}_{24} \cdot 4 \mathrm{H}_{2} \mathrm{O}$ & 0,05 & & $\mathbf{0 , 0 5}$ \\
\hline $\mathrm{AlCl}_{3}$ & 0,05 & & $\mathbf{0 , 0 5}$ \\
\hline $\mathrm{CoCl}_{2} \cdot 6 \mathrm{H}_{2} \mathrm{O}$ & 0,05 & & $\mathbf{0 , 0 5}$ \\
\hline $\mathrm{NiCl}_{2} \cdot 6 \mathrm{H}_{2} \mathrm{O}$ & 0,092 & & 0,092 \\
\hline EDTA & 0,5 & & $\mathbf{0 , 5}$ \\
\hline $\mathrm{HCl}$ concentrado & $1 \mathrm{~mL}$ & & $1 \mu \mathrm{L} / \mathrm{L}$ \\
\hline $\mathrm{Na}_{2} \mathrm{SeO}_{3} \cdot 5 \mathrm{H}_{2} \mathrm{O}$ & 0,1 & & $\mathbf{0 , 1}$ \\
\hline \multicolumn{4}{|l|}{ 2. Vitaminas (Wolin et al., 1963) } \\
\hline Ácido fólico & 0,010 & \multirow{10}{*}{2} & $\mathbf{0 , 0 2 0}$ \\
\hline Ácido p-aminobenzóico & 0,025 & & $\mathbf{0 , 0 5 0}$ \\
\hline Ácido pantotênico & 0,025 & & $\mathbf{0 , 0 5 0}$ \\
\hline Ácido tióico & 0,025 & & $\mathbf{0 , 0 5 0}$ \\
\hline Biotina & 0,010 & & $\mathbf{0 , 0 2 0}$ \\
\hline Vitamina B1 (Tiamina) & 0,025 & & $\mathbf{0 , 0 5 0}$ \\
\hline Vitamina B2 (Riboflavina) & 0,025 & & $\mathbf{0 , 0 5 0}$ \\
\hline Vitamina B5 (Nicotinamida) & 0,025 & & $\mathbf{0 , 0 5 0}$ \\
\hline Vitamina B6 (Piridoxina) & 0,050 & & 0,100 \\
\hline Vitamina B12 (Cianocobolamina) & 0,0001 & & $\mathbf{0 , 0 0 0 2}$ \\
\hline
\end{tabular}




\subsection{Reator em batelada}

O ensaio em batelada ( $2^{\mathrm{a}}$ etapa) foi realizado para avaliar a produção de metano e crescimento das bactérias ferro-redutoras na presença de aroclor 1260 (Figura 4-4). Os ensaios foram executados em triplicata em reatores de $100 \mathrm{~mL}$ com $50 \mathrm{~mL}$ de headspace e 50 $\mathrm{mL}$ de volume reacional. Nesses reatores foram usados $0,62 \mathrm{~g}$ de espuma de poliuretano, padronizado por Correa (2011).

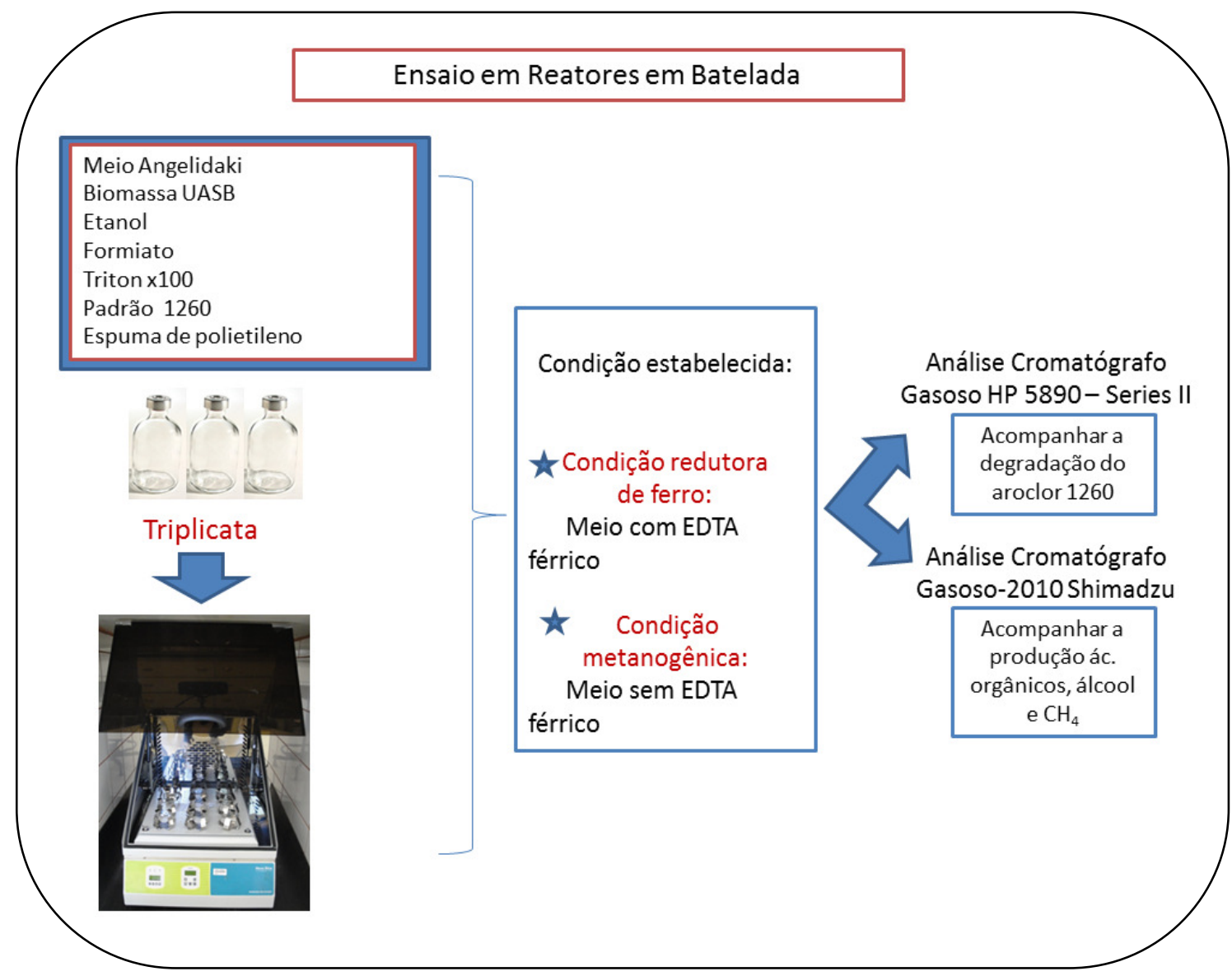

Figura 4-4. Fluxograma das etapas do ensaio em batelada

Como Hirasawa et al. (2008) verificaram que o inóculo de avícola é preferencialmente metanogênico, esta condição nos reatores em batelada se estabeleceu naturalmente. Assim, os reatores metanogênicos foram compostos de meio basal descrito por Angelidaki et al. (1990) (Tabela 4-1), formiato (680 mg/L) e etanol (46 g/L) como fonte de 
carbono, bicarbonato como tampão, Triton 100x (10\%) para solubilizar o aroclor 1260 (0,5mL/L), solução de vitaminas (Wolin et al., 1963) e solução redutora de sulfeto de sódio (5\%). Para simular a condição redutora de ferro este mesmo meio foi acrescido de EDTA férrico $(1,84 \mathrm{~g} / \mathrm{L})$ (Tabela 4-2).

Tabela 4-2. Composição do meio de cultura para a comparação dos reatores metanogênicos e ferro redutores.

\begin{tabular}{|c|c|c|}
\hline & $\begin{array}{c}\text { Condição } \\
\text { Metanogênica }\end{array}$ & $\begin{array}{c}\text { Condição } \\
\text { Redutora de ferro }\end{array}$ \\
\hline $\begin{array}{l}\text { Material suporte - } \\
\text { Espuma de poliuretano }\end{array}$ & $0,62 \mathrm{~g}$ & $0,62 \mathrm{~g}$ \\
\hline Biomassa & $5 \mathrm{~mL}$ & $5 \mathrm{~mL}$ \\
\hline Meio basal Angelidaki & $43,773 \mathrm{~mL}$ & $43,773 \mathrm{~mL}$ \\
\hline Solução A - & $0,438 \mathrm{~mL}$ & $0,438 \mathrm{~mL}$ \\
\hline Solução B - & $0,088 \mathrm{~mL}$ & $0,088 \mathrm{~mL}$ \\
\hline Solução C - Sais minerais & $0,044 \mathrm{~mL}$ & $0,044 \mathrm{~mL}$ \\
\hline Água & $43,20 \mathrm{~mL}$ & $43,20 \mathrm{~mL}$ \\
\hline Formiato $(10 \mathrm{mM})$ & $0,27 \mathrm{~mL}$ & $0,27 \mathrm{~mL}$ \\
\hline Etanol (10 mM) & $0,027 \mathrm{~mL}$ & $0,027 \mathrm{~mL}$ \\
\hline Bicarbonato & $0,45 \mathrm{~mL}$ & $0,45 \mathrm{~mL}$ \\
\hline Triton 100X (10\%) & $0,045 \mathrm{~mL}$ & $0,045 \mathrm{~mL}$ \\
\hline Aroclor $1260(0,2 \mu \mathrm{g} / \mathrm{L})$ & $0,045 \mathrm{~mL}$ & $0,045 \mathrm{~mL}$ \\
\hline Solução vitaminas & $0,09 \mathrm{~mL}$ & $0,09 \mathrm{~mL}$ \\
\hline $\begin{array}{l}\text { Solução redutora de sulfeto de } \\
\text { sódio }(5 \%)\end{array}$ & $0,3 \mathrm{~mL}$ & $0,3 \mathrm{~mL}$ \\
\hline EDTA férrico & -------- & $0,08 \mathrm{~g}$ \\
\hline
\end{tabular}

O reator controle da condição metanogênica (M0) foi inoculado com biomassa inativada por meio da esterilização em autoclave, a $120^{\circ} \mathrm{C}$ por 1 hora, sem o meio suporte (espuma poliuretano). Assim o reator controle constituiu-se de espuma como material suporte, meio basal descrito por Angelidaki et al. (1990), biomassa inativada e aroclor 1260. 
O material suporte foi cortado em cubos de $1 \mathrm{~cm}^{3}$, autoclavado a $120^{\circ} \mathrm{C}$ por 15 minutos e seco em estufa a $40^{\circ} \mathrm{C}$. Neste ensaio a massa do material suporte foi pesada e colocada em frascos de antibióticos de $100 \mathrm{~mL}$. Após a adição de $45 \mathrm{~mL}$ de meio basal, o headspeace foi submetido a atmosfera de $\mathrm{N}_{2} / \mathrm{CO}_{2}$ (70/30\%), e inoculado $5 \mathrm{~mL}$ de biomassa. Logo após, foi adicionado aroclor 1260.

Os frascos foram lacrados com tampas de Teflon e lacres de alumínio, de acordo com as técnicas de manipulação anaeróbia estrita descrita por Vazoller (1995). Os reatores foram mantidos sob agitação orbital de $150 \mathrm{rpm}$ e temperatura constante de $30^{\circ} \mathrm{C}$. Amostra do headspace foi coletada durante aproximadamente 600 horas para a análise do potencial metanogênico. Para a análise espectrofotométrica de ferro total e cromatográfica de PCBs totais e de ácidos orgânicos voláteis amostras do meio reacional foram coletadas após 1440 horas de operação para se garantir a saturação dos suportes e adaptação da biomassa ao PCB. Neste momento também se coletou amostras da biomassa para análise biológica.

\subsubsection{Analises Fisico-químicas e cromatográficas}

Análises físico-químicas e cromatográficas foram realizadas em amostras coletadas dos reatores em batelada da $2^{\mathrm{a}}$ etapa. $\mathrm{O}$ metano foi analisado por meio de cromatógrafo gasoso GC-2010 SHIMADZU, equipado com detector de condutividade térmica (TCD), com coluna Carboxen 1010 plot $30 \mathrm{~m}$ x 0,53 mm, sendo o gás de arraste o argônio (grau cromatográfico). As temperaturas do forno, da coluna e do detector foram $200^{\circ} \mathrm{C}, 30^{\circ} \mathrm{C}$ e $230^{\circ} \mathrm{C}$, respectivamente. O volume de amostra injetado foi de $500 \mu \mathrm{L}$. A retirada do gás presente nos frascos foi realizada com seringa de $1,0 \mathrm{~mL}$.

Em relação a determinação de ferro, Viollier et al. (2000), reavaliaram a utilização do corante, ferrozina, que indica a presença do ferro, e propuseram um sistema espectrofotométrico para a determinação de ferro com este corante. 
A ferrozina, hidrato de sal monossódico de 3-(2-piridil)-5,6-bis-(4-ácido fenil sulfônico)-1,2,4-triazina), reagente proposto por Stookey (1970), reage com ferro bivalentes para formar um complexo magenta estável. O complexo ferrozina-Fe ${ }^{2}$ produz um cromóforo vermelho e a sua absorbância pode ser determinada a 562nm. Quando Fe(III) está presente em solução (como um verdadeiro complexo dissolvido ou como colóides com diâmetros menores do que o tamanho dos poros da membrana de filtração) pode reagir com a ferrozina, interferindo, assim, com a coloração do complexo ferroso (SIFFERT, 1989 apud VIOLLIER et al., 2000).

Mistura de $\mathrm{Fe}(\mathrm{II})$ dissolvido e $\mathrm{Fe}(\mathrm{III})$ reagindo com a ferrozina leva à seguinte absorção:

$$
A_{1}=\varepsilon_{\mathrm{Fe}(\mathrm{II})} l C_{\mathrm{Fe}(\mathrm{II})}+\varepsilon_{\mathrm{Fe}(\mathrm{III})} l C_{\mathrm{Fe}(\mathrm{III})}
$$

sendo:

$\mathrm{A}_{1}=$ absorbância medida antes da etapa de redução,

$\varepsilon_{\mathrm{Fe}(\mathrm{II})}$ e $\varepsilon_{\mathrm{Fe}(\text { (III) }}=$ coeficientes de absorção molar,

$1=$ comprimento do caminho óptico e

$\mathfrak{l C}_{\mathrm{Fe} \text { (II) }}$ e $\mathrm{lC}_{\mathrm{Fe} \text { (III) }}=$ concentrações de espécies $\mathrm{Fe}$.

Após a adição de um agente redutor e um tampão, Fe(III) reduz-se a $\mathrm{Fe}(\mathrm{II})$, aumentando, assim a concentração do complexo Fe(II) e ferrozina em solução.

Todas as soluções foram preparadas em água MilliQ. Os seguintes reagentes foram usados:

- ferrozina: $10^{-2} \mathrm{~mol} / \mathrm{L}$ preparado em acetato de amônio $\left(\mathrm{CH}_{3} \mathrm{COONH}_{4}\right)$ solução de $10^{-1} \mathrm{~mol} / \mathrm{L}$. 
- agente redutor foi o cloridrato de hidroxilamina $\left(\mathrm{H}_{2} \mathrm{NOH} . \mathrm{HCl}\right): 1,4 \mathrm{~mol} / \mathrm{L}$ preparado em solução de ácido clorídrico de grau analítico 2 mol/L.

- tampão, acetato de amônio, solução de 10 mol/L pH ajustado para 9,5 com solução de hidróxido de amônio $\left(\mathrm{NH}_{4} \mathrm{OH}\right)$.

- padrões foram preparados a partir de uma solução estoque de Fe (III) de 1000 $\mu \mathrm{g} / \mathrm{mL}\left(1,786 \times 10^{-2} \mathrm{~mol} / \mathrm{L}\right.$ de $\mathrm{FeCl}_{3}$ em $\left.\mathrm{HCl} 10^{-2} \mathrm{~mol} / \mathrm{L}\right)$ diluído em água deionizada.

Alíquota de 2,0 mL da amostra foi transferida para um tubo e tratada com 2,0 mL de ácido clorídrico $(0,5 \mathrm{M})$ para preservar o ferro bivalente na amostra mesmo entrando em contato com o ar. Logo após foi adicionado $0,4 \mathrm{~mL}$ de ferrozina. $\mathrm{O}$ tempo de reação aplicado foide 10 minutos para completar a redução de $\mathrm{Fe}(\mathrm{III})$ na solução, a absorbância $\mathrm{A}_{1}$ foiregistrada. $\mathrm{Na}$ mistura foiadicionado $600 \mathrm{~mL}$ de hidroxilamina (reagente redutor), adicionado juntamente com o tampão $(200 \mathrm{~mL})$, e após 12 horas foi medida a absorbância da etapa reduzida que equivale ao ferro total da amostra. Por meio das equações citadas anteriormente foi realizadoo cálculo de todas as formas de ferro na amostra. A partir da elaboração da curva padrão e da utilização da regressão linear da absorbância em função da concentração do padrão, calculou-se a quantidade de compostos férricos $\left(\mathrm{Fe}^{3+}\right)$ e ferrosos $\left(\mathrm{Fe}^{2+}\right)$ presentes nas amostras do reator em batelada.

Para a determinação de ácidos orgânicos (cítrico, málico, succínico, lático, fórmico, acético, propiônico, isobutírico, butírico, isovalérico, valérico e capróico), álcoois (metanol, etanol e n-butanol), foi utilizada cromatografia líquida de alta eficiência. A metodologia foi desenvolvida no Laboratório de Processos Biológicos da Escola de Engenharia de São Carlos - USP. Para tanto, utilizou-se sistema para Cromatografia Líquida de Alta Eficiência (CLAE) SHIMADZU $^{\circledR}$ equipado com bomba LC-10ADVP, amostrador automático SIL-20A HT, forno CT-20A, dois detectores ligados em série: um detector de ultravioleta (UV) com arranjo de diodos do modelo SDP-M10 AVP, o detector por índice de refração RID-10A; além do 
controlador SCL-10AVP. A coluna utilizada foi AMINEX ${ }^{\circledR}$ HPX-87H (300 mm x 7,8 mm; BioRad) e o software Class-VP (SHIMADZU ${ }^{\circledR}$ ). Os ácidos foram detectados pelo SDP-M10 AVP e os demais compostos (carboidratos e alcoóis) pelo RID-10A. Como fase móvel (FM) usou-se solução de ácido sulfúrico 0,005 M. As condições operacionais da coluna foram fluxo de $0,5 \mathrm{~mL} \mathrm{~min}^{-1}$ e temperatura de $43^{\circ} \mathrm{C}$.

O preparo da amostra consistiu em $2,0 \mathrm{~mL}$ da amostra a ser analisada e adição de 80 mL de solução de ácido sulfúrico $1 \mathrm{~N}$ (2M). Em seguida, a solução a ser injetada foi filtrada em membrana de acetato de celulose com poro de $0,2 \mathrm{~mm}$.

Para a determinação de PCB o método de extração líquido/líquido (VIEIRA et al., 2007; RANTAKOKKO et al., 2009) serviu como base. O referido método constituiu-se em três etapas (Figura 4-5).

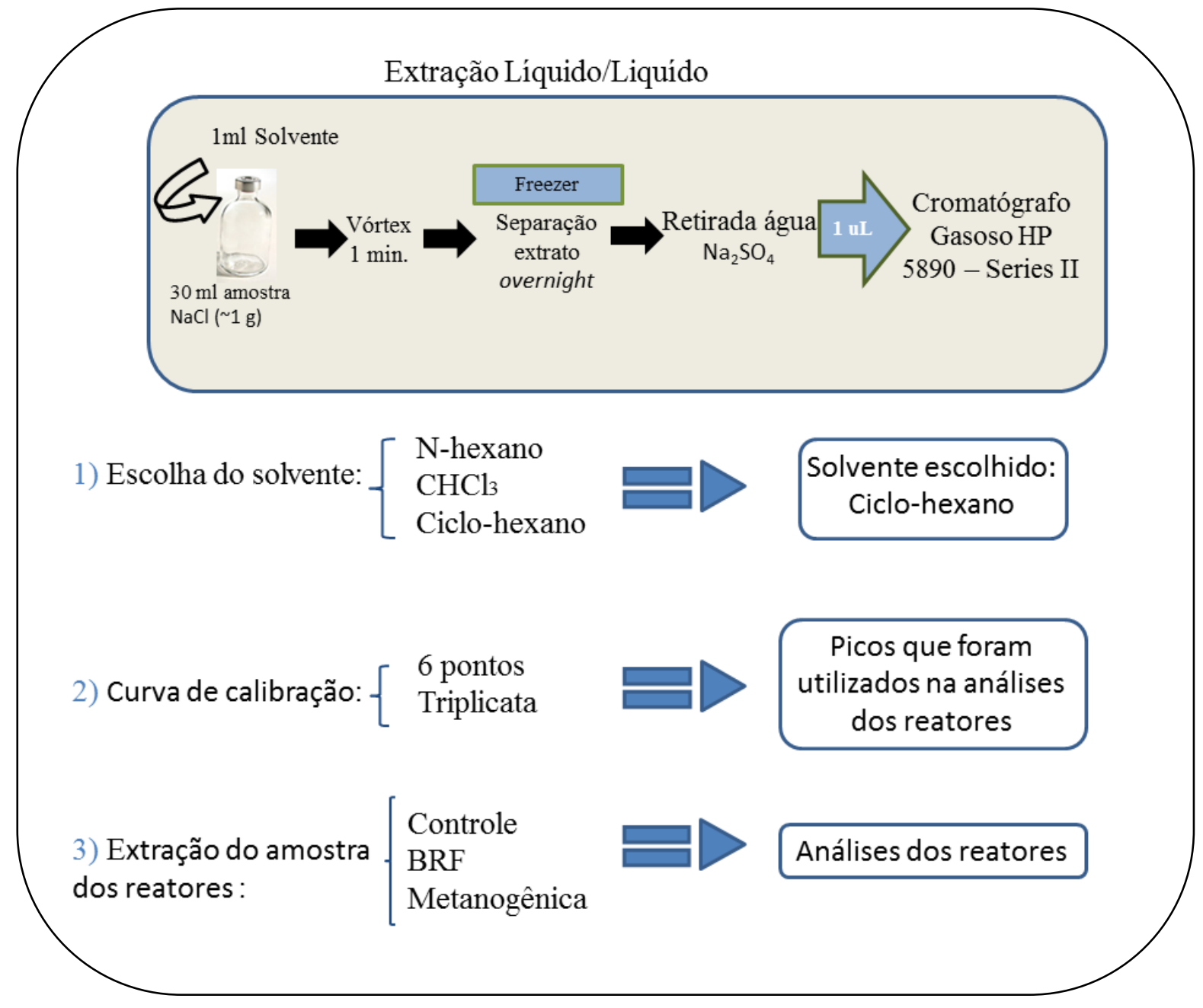


Figura 4-5. Fluxograma das etapas do método de extração líquido/líquido de PCB

Na primeira etapa, para o método de extração foram testados diferentes solventes: $n$ hexano, acetona e ciclo-hexano. A camada superior do extrato (solvente orgânico/PCB) foi injetada em cromatógrafo gasoso HP 5890 série II para análise de aroclor 1260 e determinação do melhor solvente. Foi necessário ainda retirar a fase aquosa remanescente adicionando-se $\mathrm{Na}_{2} \mathrm{SO}_{4}$ à fase orgânica para retirar a água restante na solução.

A determinação de PCB total foi realizada em cromatógrafo gasoso Hewlett-Packard, 5890 series II equipado com detector de captura de elétrons (ECD) - coluna capilar Elite - 5 Perkin Elmer $(30 \mathrm{~m}$ x 0,32 $\mathrm{mm}$ x 0,25 $\mu \mathrm{m})$. As seguintes condições cromatográficas foram realizadas: temperatura inicial do forno: $100{ }^{\circ} \mathrm{C}$ a $160{ }^{\circ} \mathrm{C}(2$ minutos $)$, a $15{ }^{\circ} \mathrm{C} / \mathrm{min}$ até $235^{\circ} \mathrm{C}$ e até $270^{\circ} \mathrm{C}$ (36 min.) a $5{ }^{\circ} \mathrm{C} / \mathrm{min}$. Temperatura do injetor de $280{ }^{\circ} \mathrm{C}$ (splitless) e do detector de $300{ }^{\circ} \mathrm{C}$ (Tabela 4-3).

Tabela 4-3. Condições cromatográficas para amostra injetada em cromatógrafo gasoso HP 5890 série II para análise de PCBs

\begin{tabular}{|c|c|}
\hline \multicolumn{2}{|c|}{ Condições cromatográficas - Método "COLEL B" } \\
\hline $\mathrm{T}_{\text {inj }}$ & $280 \square \mathrm{C} ;$ splitless \\
\hline $\mathrm{T}_{\text {det }}$ & $300 \square \mathrm{C} ;$ make-up $=\mathrm{N}_{2}, 30 \mathrm{~mL} / \mathrm{min}$ \\
\hline $\mathrm{T}_{\text {forno }}$ & $\begin{array}{l}120 \square \mathrm{C}-160 \square \mathrm{C}, 15 \square \mathrm{C} / \mathrm{min} ;- \\
235 \square \mathrm{C}(3 \mathrm{~min}), 5 \square \mathrm{C} / \mathrm{min} ;-270 \square \mathrm{C} \mathrm{(20} \\
\text { min) }\end{array}$ \\
\hline$V_{\text {inj }}$ & $1,0 \mu \mathrm{L}$ \\
\hline Gás de arraste & hidrogênio \\
\hline Coluna & $\begin{array}{l}\text { Elite-5 }(30 \mathrm{~m} \times 0,32 \times 0,25 \mu \mathrm{m}) \text {, } \\
\text { Perkin Elmer }\end{array}$ \\
\hline
\end{tabular}


O detector de captura de elétrons é uma ferramenta extremamente sensível na análise de compostos organoclorados e amplamente utilizado na rotina da maioria dos laboratórios de pesquisa (SHIBAMOTO, 1998).

A partir da solução $1 \mathrm{mg} / \mathrm{L}$ do aroclor 1260 preparada anteriormente, foi realizada a segunda etapa, que consistiu em diluir as soluções para compor a curva de calibração. Nessa fase foi usada água ultrapurificada.

$\mathrm{Na}$ última etapa foram realizadas as análises das amostras provenientes do ensaio em batelada que teve como objetivo verificara remoção de PCB em condição metanogênica e redutora de ferro. Para tanto, foi usado $30 \mathrm{~mL}$ de amostra de todos os reatores e adicionado 0,5mL de ciclo-hexano sob agitação. A camada superior do extrato (ciclo-hexano/PCB) foi retirada utilizando-se pipeta Pasteur e transferida para frasco âmbar. Retirou-se $2 \mu \mathrm{L}$ desse extrato e procedeu-se a injeção em cromatógrafo gasoso HP 5890 série II para análise de aroclor 1260.

\subsubsection{Potencial metanogênico}

A avaliação do potencial metanogênico na $2^{\mathrm{a}}$ etapa foi realizada por meio de ensaio que consistiu em avaliar a capacidade das arquéias metanogênicas em converter substrato orgânico em biogás, medindo a taxa de conversão de substratos em metano por unidade de biomassa (FLORENTINO et al. 2010).

A retirada do biogás foi realizada com seringa de 1,0 mL, todavia, foi injetado $500 \mu \mathrm{L}$. Os frascos não foram despressurizados com a finalidade de se manter a produção acumulada de biogás. A quantidade de biomassa adicionada inicialmente foi de 2,85 mg/L de STV (CORREA, 2011).

A conversão dos valores das áreas de metano $\left(\mathrm{mmols}\right.$ de $\left.\mathrm{CH}_{4}\right)$ foi realizada por meio da equação da reta padrão nas condições normais de temperatura e pressão (CNTP). Os 
valores de metano obtidos para o volume de amostragem $(500 \mu \mathrm{L})$ foram convertidos para o volume livre de cada frasco, a partir da equação 4.2:

No. de mols de $\mathrm{CH}_{4}$ no headspeace (mmol)

\section{$\left[\mathrm{CH}_{4}\right]$ amostra (mmol) X volume do headspeace $(\mathrm{mL})$} volume injetado da amostra

Os ajustes dos dados da produção de metano por sólidos totais voláteis foram realizados utilizando-se o programa Microcal Origin ${ }^{\circledR}$ através da sigmóide de Boltzmann, utilizando o algoritmo de otimização de Levenberg-Marquardt e posterior análise diferencial para determinar a velocidade máxima de produção de metano.

\subsection{Caracterização da diversidade microbiana}

\subsubsection{Número Mais Provável (NMP)}

Para estimar a população de bactérias redutoras de ferro presente no reator RAHLF operado por Correa (2011), no final da $1^{\mathrm{a}}$ etapa, foi utilizado a técnica de tubos múltiplos por meio do Número Mais Provável. O conceito é bastante antigo, idealizado por McCrady (1915), adaptado por Sakamoto (1996) para quantificação da microbiota anaeróbia. O método consiste em diluições seriadas para contagem indireta da densidade de microrganismo em líquido, utilizando tabelas de probabilidade (APHA 1975).

O procedimento consistiu na inoculação dos microrganismos provenientes do reator em meio de cultura (ANGELIDAKI et al., 1990) e solução de vitaminascom a adição de Aroclor $1260(0,2 \mu \mathrm{g} / \mathrm{L})$. Para a quantificação das bactérias redutoras de ferro foi utilizado sal sódico de EDTA férrico (1,84g/L) segundo metodologia Gould et al. (2002) adaptada por Delforno (2011). 
Para isso, foi coletado 4 espumas de poliuretano que continham o biofilme do reator RAHLF, transferidas para frasco apropriado contendo pérolas de vidro (5 g) e submetido a atmosfera de $\mathrm{N}_{2}(100 \%)$ durante 15 minutos. O frasco foi fechado com tampa de teflon e lacre de alumínio, e submetido a agitação manual em ângulo de $45^{\circ}$, durante 20 minutos (VAZOLLER,1995).

Procedeu-se a diluição seriada da amostra em água de diluição e, posteriormente, inoculação em meio de cultura descrita anteriormente.

Para a preparação da água de diluição foram utilizadas duas soluções estoque descritas nas Tabela 4-4 e Tabela 4-5.

Tabela 4-4. Solução estoque 1

\begin{tabular}{|l|c|}
\hline Solução Estoque 1 & Quantidades - q.s.p. 100 mL de água ultrapurificada \\
\hline $\mathrm{K}_{2} \mathrm{HPO}_{4}(0,2 \mathrm{M})$ & $3,48 \mathrm{~g}$ \\
\hline
\end{tabular}

Tabela 4-5. Solução estoque 2

\begin{tabular}{|l|c|}
\hline Solução Estoque 2 & Quantidades - q.s.p. 100 mL de água ultrapurificada \\
\hline $\mathrm{KH}_{2} \mathrm{PO}_{4}(0,2 \mathrm{M})$ & $2,72 \mathrm{~g}$ \\
\hline
\end{tabular}

Primeiramente, foi preparada a água anaeróbia transferindo-se $300 \mathrm{~mL}$ de água destilada para erlenmeyer e submetida ao aquecimento até entrar em ebulição. A água foi resfriada (20 minutos), sob atmosfera de $\mathrm{N}_{2}(100 \%)$. Essa água anaeróbia foi utilizada para preparar a solução de diluição.

As soluções estoque 1 e 2 foram esterilizadas em autoclave ( $1 \mathrm{~atm}, 121^{\circ} \mathrm{C}, 20$ minutos) e armazenadas em geladeira. A água de diluição foi formada pelas soluções estoque 1 e 2. Desta forma as soluções 1 e 2 foram adicionadas em frasco apropriado e o volume finalizado com água anaeróbia como descrito na Tabela 4-6. 
Tabela 4-6. Composição da água de diluição

\begin{tabular}{|l|c|}
\hline Água de diluição & Quantidades - q.s.p. 250 mL de água ultrapurificada \\
\hline Solução estoque 1 & $1 \mathrm{~mL}$ \\
\hline Solução estoque 2 & $0,25 \mathrm{~mL}$ \\
\hline
\end{tabular}

A seguir iniciou-se a distribuição da água de diluição nos frascos. Foram adicionados 9,0 mL de água de diluição em cada frasco de antibiótico $(30 \mathrm{~mL})$. Os frascos foram submetidos à atmosfera de $\mathrm{N}_{2}(100 \%)$, lacrados com tampa de teflon e lacre de alumínio. A esterilização foi realizada em autoclave a $1 \mathrm{~atm}, 121^{\circ} \mathrm{C}$, por 20 minutos.

Amesma composição do substrato sintético contendo aroclor $1260(0,2 \mu \mathrm{g} / \mathrm{L})$ foi usada) para a preparação dos frascos de contagem do NMP com a adição de 1,84 g/L de sal sódico de EDTA férrico para a indução de meio propício ao crescimento das bactérias redutoras de ferro. Tal substrato sintético foi filtrado em sistema Millipore com membrana $(0,22 \mathrm{~mm})$ previamente esterilizado em autoclave a $121^{\circ} \mathrm{C}, 1 \mathrm{~atm}$, durante 20 minutos. Após a filtração, o substrato sintético foi submetido a atmosfera de $\mathrm{N}_{2}(100 \%)$ e, posteriormente, a a troca de atmosfera com $\mathrm{N}_{2} / \mathrm{CO}_{2}(70 / 30 \%)$. A seguir foram transferidos $8,9 \mathrm{~mL}$ do meio de cultura para frascos de antibiótico de $30 \mathrm{~mL}$.

Os frascos de antibióticos e tampas foram, anteriormente, esterilizados em autoclave a $121^{\circ} \mathrm{C}$ e $1 \mathrm{~atm}$, durante 20 minutos. Os frascos foram lacrados com tampa de teflon e lacre de alumínio. Em todos os frascos de contagem foram adicionados $0,1 \mathrm{~mL}$ de solução redutora de sulfeto de sódio (5\%) (SAKAMOTO, 1996).

Anteriormente, à inoculação nos frascos de contagem do NMP, realizou-se a diluição do inóculo em condição anaeróbia. A partir da diluição seriada com água de diluição foi realizada a inoculação em meio de cultura. Para tanto, foi transferido $1 \mathrm{~mL}$ da amostra em 9 $\mathrm{mL}$ de água de diluição preparado previamente. A partir desta diluição, mais $1 \mathrm{~mL}$ foi retirado 
e transferido para outro frasco de diluição contendo novamente $9 \mathrm{~mL}$ de água de diluição, e assim, sucessivamente, até a diluição $10^{-20}$ (Figura 4-6. Esquema de distribuição da amostra nos frascos de diluição ). A transferência da amostra foi realizada com seringa estéril.

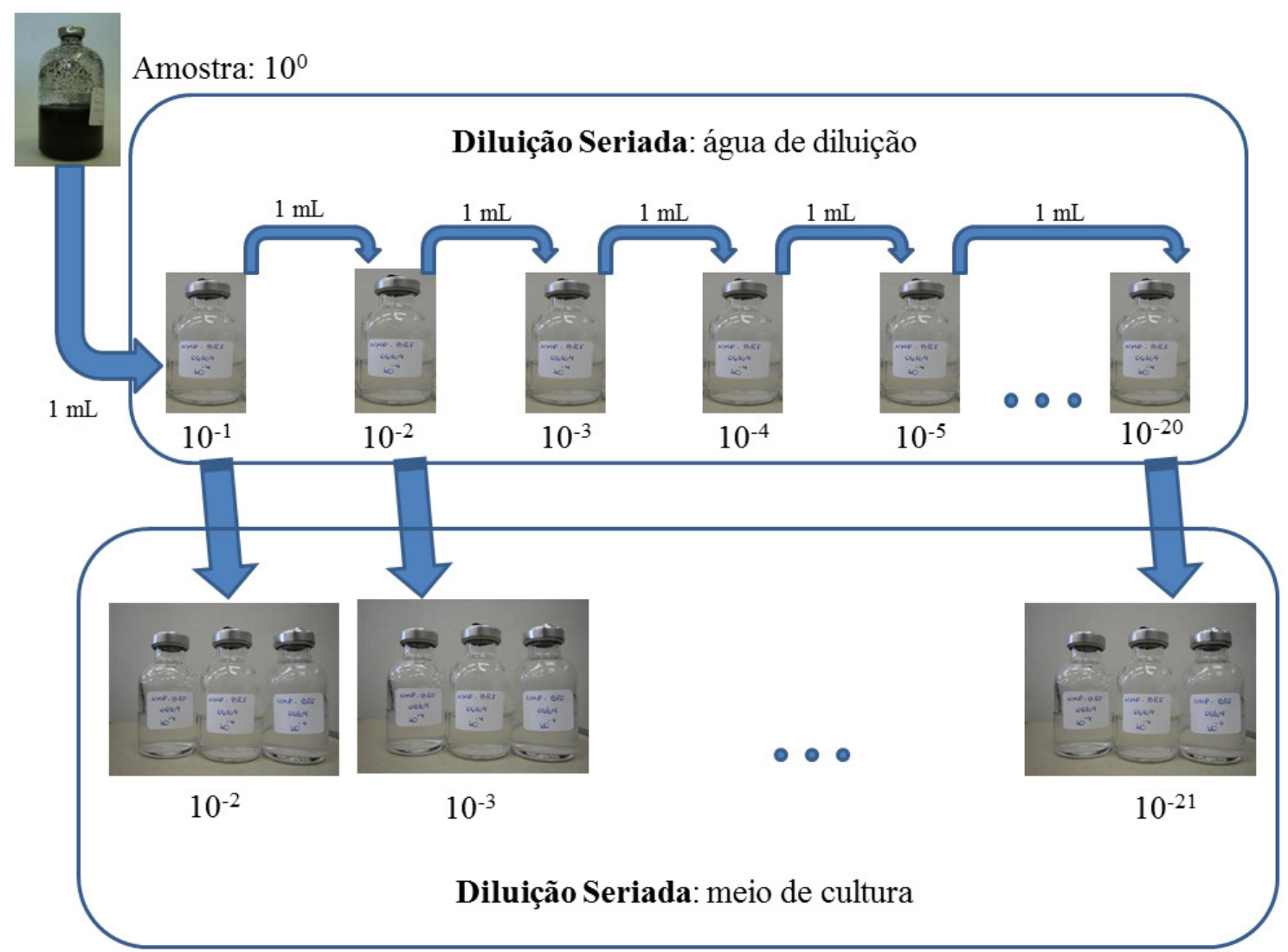

Figura 4-6. Esquema de distribuição da amostra nos frascos de diluição e quantificação por NMP

Após inoculação, os frascos de contagem (NMP) foram incubados a $30^{\circ} \mathrm{C} \pm 1^{\circ} \mathrm{C}$ durante 30 dias. As bactérias redutoras de ferro foramdetectadas pela presença de Ferro II no meio a partir da reação com ferrozina (GOULD et al. 2002). As diluições foram feitas em triplicata. Respostas positivas e negativas foram a base do cálculo para estimar o NMP, por meio da tabela padrão de probabilidade (APHA, 1975). Após a consulta da tabela foi utilizada a fórmula abaixo para calcular NMP/100 mL (eq. 4.3). 


\section{$\mathrm{NMP} / 100 \mathrm{~mL}$ Valor $\mathrm{NMP}(\mathrm{APHA}, 1975) \approx \frac{10}{\mathrm{~V}}$}

Sendo:

$\mathrm{V}=$ menor diluição da amostra da série de combinações selecionadas

\subsubsection{Microscopia óptica e de fluorescência}

As amostras dos reatores foram observadas em lâmina contendo ágar $2 \% \mathrm{e}$ recobertas por lamínula. As análises microscópicas foram realizadas em microscópio Olympus BX60, de contraste de fase e fluorescência, em câmera de captura de imagem acoplada e software Image Pro Plus.

\subsubsection{Análises filogenéticas}

Para a análise filogenética da diversidade microbiana das amostras do RAHLF, bem como, dos reatores em batelada foramutilizadastécnicas de Biologia Molecular. Na primeira etapa, as amostras retiradas do reator horizontal foram provenientes da biomassa aderida ao material suporte, biofilme aderido a parede do reator e biomassa utilizada como inóculo neste reator. Para tanto, foi utilizada a análise da diversidade para Domínio Bacteria por meio da eletroforese em gel de gradiente desnaturante (DGGE). Nessa etapa foi usada essa técnica para eleger a amostra para clonagem e sequenciamento do gene RNAr 16S.

$\mathrm{Na}$ segunda etapa, a diversidade microbiana referente às amostras retiradas dos reatores em batelada em condição metanogênica e redutora de ferro e aquelasdo RAHLF (biomassa aderida ao material suporte e biofilme aderido à parede do reator) e a biomassa utilizada como inóculo no reator horizontal, foi avaliada usando-se a técnica de PCR/DGGE para os Domínios Bacteria e Archaea.

A coleta das amostras dos reatores em batelada se deu após o término da operação dos reatores. No caso do RAHLF, as amostras foram coletadas após 180 dias de 
adição do ascarel. As amostras foram centrifugadas com tampão PBS (1X) e armazenadas a temperatura de $-20{ }^{\circ} \mathrm{C}$.

\subsubsection{Extração de DNA}

A extração de DNA para as análises da eletroforese em gel de gradiente desnaturante (DGGE) e clonagem foi realizada por meio de método direto utilizando glass beads e mistura de fenol/ clorofórmio/ tampão, na relação de 1/ 1/ 1 em volume seguindo o procedimento de Griffiths et al. (2000) com algumas modificações em virtude do material biológico em estudo.

\subsubsection{Clonagem}

A comunidade microbiana presente no reator RAHLF foi analisada em relação ao Domínio Bacteria por meio de sequiências parciais do DNA ribossomal 16S. Para tal finalidade, fragmentos do DNA ribossomal 16S foram obtidos pela metodologia de PCR, utilizando como molde o DNA genômico extraído diretamente da amostra de acordo com protocolo de Griffiths et al. (2000) modificado. Os primers (oligonucleotídeos sintéticos) usados para a reação de PCR foram 27F e 1100R (Tabela 4-7), homólogos às extremidades conservadas do gene RNAr 16S de bactérias (LANE, 1991) nas condições apresentadas na Tabela 4-8.

Tabela 4-7. Primers para a amplificação da região 16 S do domínio Bacteria.

\begin{tabular}{|l|l|}
\hline Primers & Sequencia \\
\hline $27 \mathrm{~F}$ & (5'-AGA GTT TGA TCC TGG CTC AG-3') \\
\hline $1100 \mathrm{R}$ & (5'-AGG GTT GCG CTC GTT G-3') \\
\hline
\end{tabular}


Tabela 4-8. Programação do Termociclador para os primers do domínio Bacteria

\begin{tabular}{|c|c|c|c|c|c|c|}
\hline $\begin{array}{l}\text { No. } \\
\text { Ciclos }\end{array}$ & $\begin{array}{l}\text { Desnaturação } \\
\text { inicial }\end{array}$ & Desnaturação & Anelamento & Extensão & $\begin{array}{l}\text { Extensão } \\
\text { final }\end{array}$ & Resfriamento \\
\hline 30 & $94{ }^{\circ} \mathrm{C}$ & $94{ }^{\circ} \mathrm{C}$ & $55^{\circ} \mathrm{C}$ & $72^{\circ} \mathrm{C}$ & $72^{\circ} \mathrm{C}$ & $4{ }^{\circ} \mathrm{C}$ \\
5 minutos & 45 segundos & 45 segundos & $\begin{array}{c}105 \\
\text { segundos }\end{array}$ & $\begin{array}{c}7 \\
\text { minutos }\end{array}$ & $\infty$ \\
\hline
\end{tabular}

A purificação do produto de PCR foi realizada utilizando Kit Illustra GFX DNA and Gel Band Purification e especificações detalhadas no manual. A clonagem em células competentes E. coli foi feita utilizando os produtos de PCR purificados e $50 \mathrm{ng}$ do vetor plasmidial pGEM Easy Vector System I, de acordo com as especificações do fabricante.

As amostras foram seqüenciadas em seqüenciador automático 310 ABI Prism (Applied Biosystem). As seqüênciasparciais de RNAr 16S obtidas foram analisadas no programa Seqman (Lasergene DNA Star) e comparadas com as seqüências de organismos representados na base de dados do Genbank (http:www.ncbi.nlm.nih.gov) utilizando-se a ferramenta Basic Local Aligment Search Tool (BLASTn). Os nucleotídeos alinhados foram utilizados para construir a árvore filogenética de consenso utilizando o algoritmo de Neighbor-joining (SAITOU e NEI, 1987) do software Mega versão 5.0 (TAMURA et al., 2011), seguindo os procedimentos sintetizados na Figura 4-7. Análises de bootstrap foram baseadas em 500 reamostragens. 


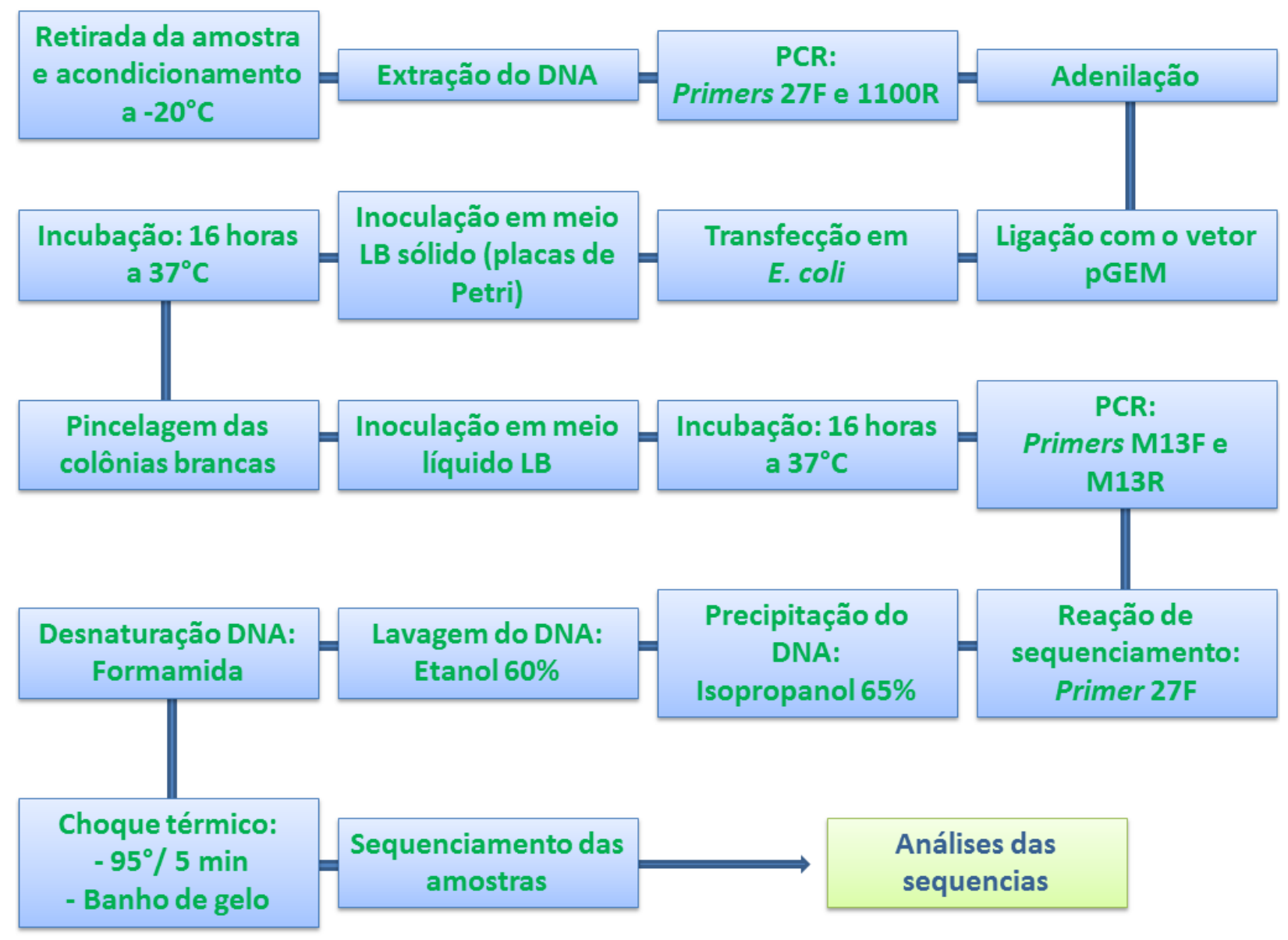

Figura 4-7. Sequencia de passos da retirada das amostras do reator até o sequenciamento

\subsubsection{DGGE}

A diversidade microbiana referente à biomassa do reator RAHLF ( $1^{\text {a }}$ etapa $)$ e dos reatores em batelada juntamente com a do reator RAHLF ( $2{ }^{a}$ etapa), foi avaliada usando-se a técnica de PCR/DGGE (Figura 4-8). 


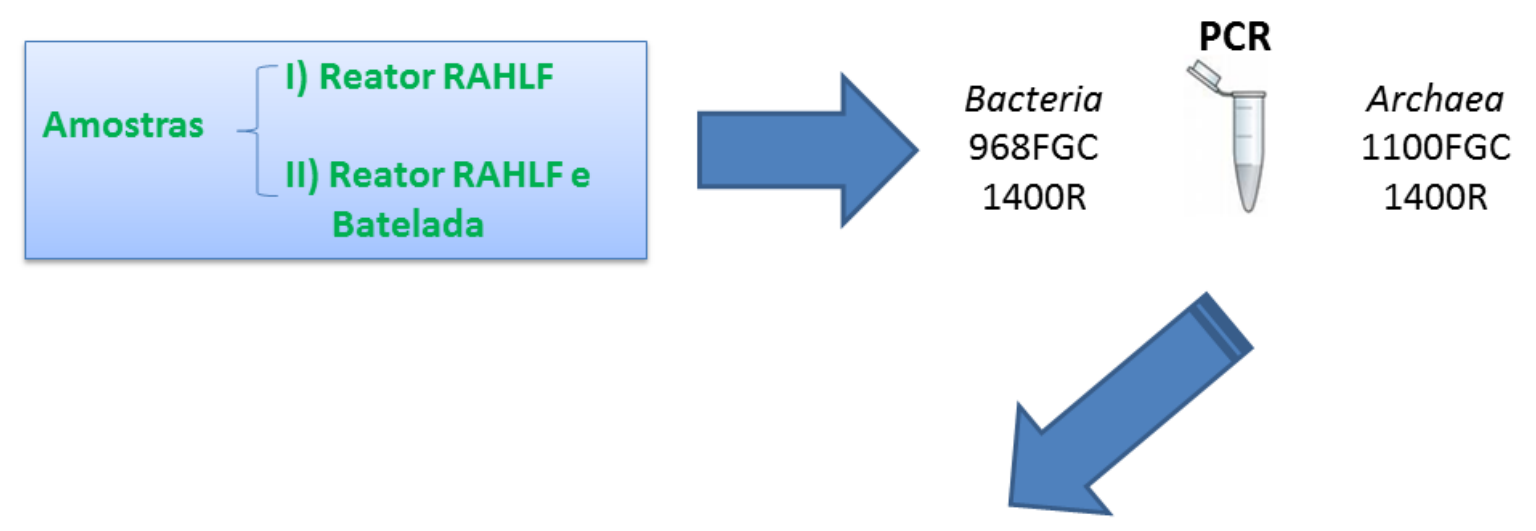

\section{DGGE \\ Dendograma}

Figura 4-8. Fluxograma experimental da análise filogenética da comunidade microbiana

Para primers filogenéticos do Domínio Bacteria (968 FGC e 1400 R) foram utilizadas as condições de amplificação descritas por Nielsen et al. (1999).Para os primers do Domínio Archaea (1100 FGC e 1400 R) foram utilizadas as condições descritas por Kudo et al. (1997). O produto amplificado foi analisado em gel de agarose 1,4 \% para ser utilizado na eletroforese em gel de gradiente desnaturante (DGGE) segundo Muyzer et al. (1993).

Tabela 4-9. Primers utilizados no PCR/DGGE

\begin{tabular}{lll}
\hline $\begin{array}{l}\text { Grupo de } \\
\text { Microrganismos }\end{array}$ & \multicolumn{1}{c}{ Primers } & Referência \\
\hline Archaea & 1100 F GC & Kudo et al.(1997) \\
& $1400 \mathrm{R}$ & \\
Bacteria & 968 F GC & $\begin{array}{l}\text { Nielsen et al. } \\
(1999)\end{array}$ \\
& $1392 \mathrm{R}$ & \\
\hline
\end{tabular}

Para as reações de amplificação do fragmento do RNA 16S (PCR) foram usados 0,5 $\mu \mathrm{M}$ de cada primer, $5 \mu \mathrm{M}$ de dNTPs (Invitrogen $\left.{ }^{\circledR}\right)$, $(0,5 \mu \mathrm{L}) 1$ Unidade de Taq DNA 
polymerase (Invitrogen ${ }^{8}$ ), e aproximadamente $2 \mu \mathrm{L}$ de DNA genômico no programa para amplificação do gene RNAr 16S (Tabela 4-10).

Tabela 4-10. Programação da reação de PCR para amplificação do RNAr 16S

\begin{tabular}{llllllll}
\hline Domínio & $\begin{array}{l}\text { Desnaturação } \\
\text { inicial }\end{array}$ & $\begin{array}{l}\text { No. } \\
\text { ciclo }\end{array}$ & Desnaturação & Anelamento & Extensão & $\begin{array}{l}\text { Extensão } \\
\text { final }\end{array}$ & Resfriamento \\
\hline Archaea & $94{ }^{\circ} \mathrm{C}$ & 35 & $94{ }^{\circ} \mathrm{C}$ & $55^{\circ} \mathrm{C}$ & $72^{\circ} \mathrm{C}$ & $72{ }^{\circ} \mathrm{C}$ & $4{ }^{\circ} \mathrm{C}$ \\
& $5 \mathrm{~min}$ & & $1 \mathrm{~min}$ & $1 \mathrm{~min}$ & $1 \mathrm{~min}$ & $7 \mathrm{~min}$ & $\infty$ \\
\hline Bacteria & $94{ }^{\circ} \mathrm{C}$ & 35 & $94{ }^{\circ} \mathrm{C}$ & $55^{\circ} \mathrm{C}$ & $72{ }^{\circ} \mathrm{C}$ & $72{ }^{\circ} \mathrm{C}$ & $4{ }^{\circ} \mathrm{C}$ \\
Muyzer & $7 \mathrm{~min}$ & & $45 \mathrm{seg}$ & $45 \mathrm{seg}$ & $1 \mathrm{~min}$ & $10 \mathrm{~min}$ & $\infty$ \\
\hline
\end{tabular}

O produto da PCR, com o grampo GC, foi utilizado para o DGGE e o preparo das placas foi realizado de acordo com Sakamoto (2001). Tanto para o Domínio Archaea quanto para o Domínio Bacteria foi usado gradiente de $45 \%$ e $65 \%$ (MUYZER et al. 1993). As soluções do gel gradiente desnaturante foram preparadas com gel acrilamida (40\%), solução TAE 50X, formamida e uréia. Para as placas de gel foram utilizados $14 \mathrm{~mL}$ do gel na concentração almejada, $100 \mu \mathrm{L}$ de APS $10 \%$ (persulfato de amônia) e $10 \mu \mathrm{L}$ de Temed (tetrametiletilenodiamina).

As placas solidificadas do gel foram transferidas para a cuba eletroforética contendo 140 mL de TAE 50X em 7 L de água ultra-purificada. As amostras foram aplicadas nos poços do gel ( $24 \mu \mathrm{L}$ de amostra e $6 \mu \mathrm{L}$ de corante para DGGE) e permaneceram na cuba (175 Volts) a $65 \%$ por 16 horas. Transcorrido o tempo de corrida, os géis foram transferidos para uma bandeja com água destilada e brometo de etídio por 15 minutos e então, foi observada em fotodocumentador Eagle Eye TM III (Stratagene) sob exposição a 254 nm UV, acoplada a computador com o programa Eagle Sight para análise e armazenamento das imagens. As bandas foram analisadas através do programa Bionumerics versão 2.5. 
“Crê em ti mesmo, age e verá os resultados. Quando te esforças, a vida também se esforça para te ajudar." 


\section{RESULTADOS E DISCUSSÃO}

\section{1 - $1^{\text {a }}$ etapa - Caracterização da biomassa presente no RAHLF}

\subsubsection{Caracterização filogenética}

As amostras do biofilme do RAHLF alimentado com ascarel (1mL/L) (CORREA, 2011) foi coletada após 180 dias de operação. Essas amostras (biofilme da espuma de poliuretano e biofilme amarelado) foram submetidas a análise de PCR/DGGE para comparação da diversidade microbiana com aquela do inóculo (Figura 5-1).

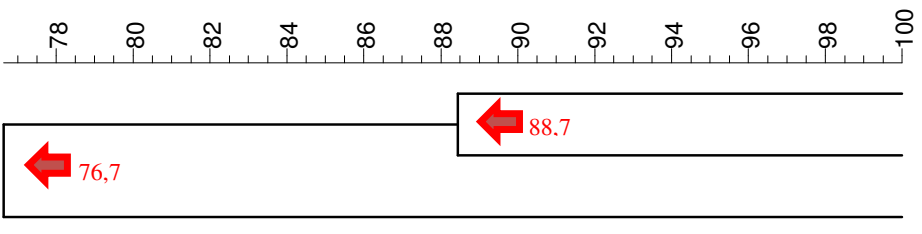

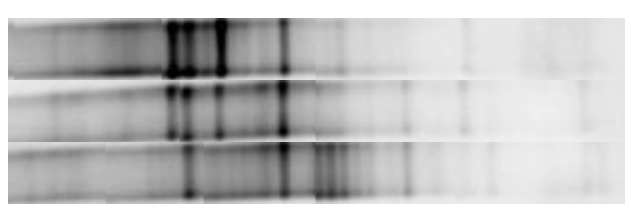

Inóculo

Suporte

Biofilme

Figura 5-1. Dendograma baseado no coeficiente de correlação de Pearson, a partir dos padrões de bandas do DGGE com set de primer para o Domínio Bacteria (primers 968F-GC e 1400R) da biomassa aderida ao material suporte, biofilme aderido à parede do reator e inóculo.

Por meio da análise de similaridade observou-se que as populações de bactérias do inóculo e aquelas do material suporte (biomassa imobilizada em espuma de poliuretano) foram $88,7 \%$ (Figura 5-1) similares. Todavia, verificou-se menor similaridade $(76,7 \%)$ entre as populações do inóculo e imobilizada no suporte em relação ao biofilme aderido a parede do reator (biofilme amarelado). Esse biofilme estava envolvido em camada de óleo, portanto, apresentando coloração amarelada. Provavelmente, devido a presença de caminhos preferenciais ocorreu acúmulo do óleo na parede do reator favorecendo a seleção de outras populações de microrganismos. Observou-se maior número de bandas no biofilme aderido a 
parede do reator, sugerindo que a comunidade foi mais diversificada, e favorecida devido a presença do ascarel. Desse modo, justifica-se a escolha dessa amostra para a realização da clonagem e sequenciamento e do NMP.

Por meio das análises de clonagem e sequenciamento de fragmentos do gene RNAr 16S do consórcio microbiano do biofilme amarelado estabelecido na parede do RAHLF foram obtidos 78 clones. Os fragmentos sequenciados tiveram tamanho médio de 406 pares de base $(\mathrm{pb})$.

Os clones obtidos da amostra do biofilme foram relacionados aos seguintes filos: Thermogae, Proteobacteria (Classes Betaproteobacteria e Deltaprotebacteria), Firmicutes, Synergistetes, Spirochaetes, Aminanaerobia, Chloroflexi, Chlorobi e Deferribacteres, além de Bactérias não cultivadas (Figura 5-2 e Tabela 5-1). Na Figura 5-3 encontra-se a árvore filogenética construída a partir dos clones da amostra do biofilme amarelado.

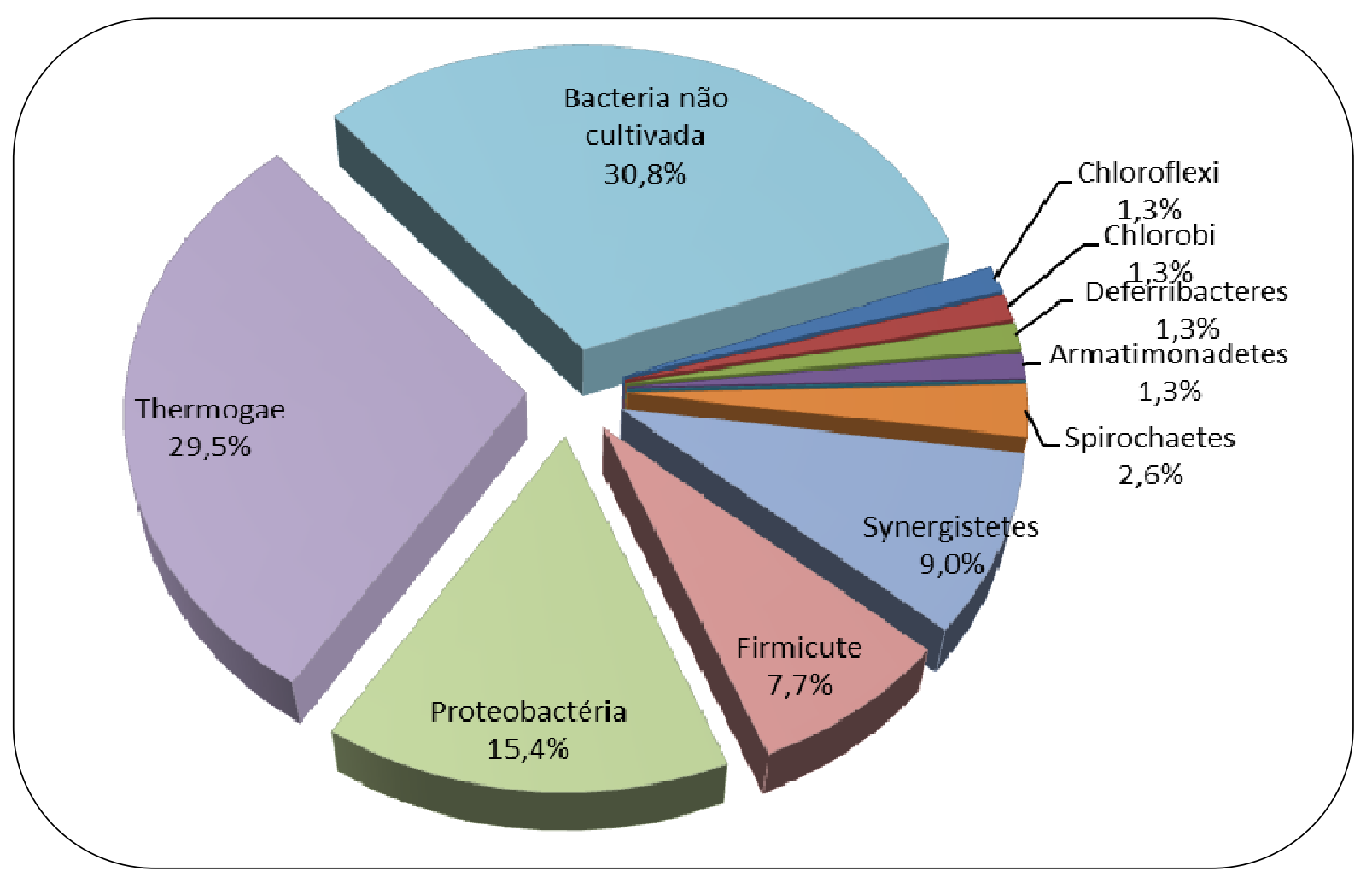

Figura 5-2. Proporção dos grupos filogenéticos do biofilme aderido na parede do RAHLF 
Rossetti et al. (2003) investigaram comunidade microbiana anaeróbia envolvida na remoção redutiva de cloro do tetracloroeteno a cloreto de vinila, por meio da clonagem e sequenciamento. Os autores obtiveram clones relacionados a Spirochaetes $(56,6 \%)$, Firmicutes (18,5\%), Chloroflexi (15,4\%), Bacteroidetes (6,3\%), Synergistetes $(1,1 \%)$ e bactérias não cultivadas $(1,1 \%)$. Correa (2011) por meio de sequenciamento de bandas recortadas do DGGE também obteve as seguintes porcentagens: Filos Thermogae, Proteobacteria, Firmicutes, Spirochaetes, Chloroflexi e Chlorobi. Nesse trabalho, a maior porcentagem de clones foi relacionada ao Filo Thermogae $(29,1 \%)$ e Proteobacteria $(15,2 \%)$.

Pode-se observar que representantes dos filos Spirochaetes, Chloroflexi e Firmicutes foram encontrados por Rossetti et al. (2003) e Correa (2011) e, também, na amostra do biofilme amarelado desse estudo. Aparentemente, estes grupos se estabeleceram mesmo na presença de compostos clorados, significando resistência á presença de compostos tóxicos. 
Tabela 5-1. Identificação dos clones do biofilme amarelado para o Domínio Bacteria

\begin{tabular}{|c|c|c|c|c|}
\hline Clones & $\mathbf{N}^{\circ}$ Acesso & Microrganismo & $\begin{array}{l}\text { Similarida } \\
\text { de }\end{array}$ & Referência \\
\hline 33,84 & JF773298.1 & Spirochaetaceae não cultivada & $97 \%$ & Das et al., 2011 (Não publicado ) \\
\hline \multirow{2}{*}{$24,71,77,95$} & AB623229.1 & Synergistaceae & $99 \%$ & Honda et al., 2011 ( Não publicado ) \\
\hline & EU721942.1 & Synergistes não cultivada & $98 \%$ & Pham, et al., 2009 \\
\hline $21,23,69$ & CU926332 & Synergistetes não cultivada & $99 \%$ & Riviere et al., 2009 \\
\hline 120 & EU887792.1 & Deferribacteres não cultivada & $98 \%$ & Nayak e Kale, 2008 (Não publicado) \\
\hline \multirow{3}{*}{$\begin{array}{c}1,2,10,12,13,76,82,89,96,103,106 \\
114,4,36,27,93,18,25,66,78,90,99,108\end{array}$} & CU923080.1 & Thermotogae não cultivada & $100 \%$ & Riviere et al., 2009 \\
\hline & HМ003102.1 & Thermotogales & $99 \%$ & Nesbo et al., 2010 \\
\hline & JN202701 & Thermotogaceae não cultivada & $98 \%$ & $\begin{array}{l}\text { Cheng e Lu } \\
2011 \text { (Não publicado) }\end{array}$ \\
\hline \multirow{2}{*}{7,81} & AY275432.1 & Brachymonas petroleovorans & $100 \%$ & Rouviere et al. 2003 \\
\hline & EU037911.1 & Brachymonas sp. não cultivada & $99 \%$ & Manickam et al., 2010 \\
\hline \multirow{2}{*}{$35,88,98$} & GQ390421.1 & Methylobacillus sp .não cultivada & $98 \%$ & Sun et al., 2010 \\
\hline & GU980086 & Bactéria não cultivada & $98 \%$ & $\begin{array}{l}\text { Kapley e Purohit } \\
2010 \text { (Não publicado) }\end{array}$ \\
\hline \multirow{2}{*}{ 6,11,67,72,86,91,104 } & AB231802.1 & Bactéria anaeróbia não cultivada & $99 \%$ & Chen et al, 2005 ( Não publicado ) \\
\hline & EF059536.1 & Geobacteraceae & $94 \%$ & Bedard et al., 2007 \\
\hline 22 & CU924963 & Chlorobi não cultivada & $98 \%$ & Riviere et al., 2009 \\
\hline \multirow{2}{*}{9} & GQ183240 & Chloroflexi não cultivada & $97 \%$ & Allen et al., 2010 \\
\hline & EU266797 & Chloroflexi não cultivada & $92 \%$ & Winderl et al. 2008 \\
\hline \multirow[b]{2}{*}{75} & JN692227 & Armatimonadetes não cultivada & $95 \%$ & Delforno et al. 2012 \\
\hline & EF393534.1 & Bactéria não cultivada & $94 \%$ & 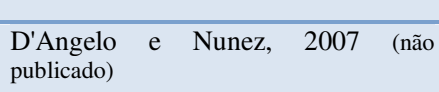 \\
\hline \multirow{2}{*}{$79,92,100$} & CU918236.1 & Firmicutes não cultivada & $99 \%$ & Riviere et al., 2009 \\
\hline & CU918191.1 & Firmicutes não cultivada & $99 \%$ & Riviere et al., 2009 \\
\hline 117 & AY548783.1 & Clostridium sp. & $97 \%$ & Kaksonen et al., 2004 \\
\hline 5 & EU498380.1 & Syntrophomonas sp. & $100 \%$ & Rowe et al., 2008 \\
\hline \multirow{2}{*}{54} & Y17763.1 & Sporomusa sp. & $95 \%$ & Rosencrantz et al. 1999 \\
\hline & JN692219 & Sporomusa sp não cultivada & $100 \%$ & Delforno et al. 2012 \\
\hline \multirow{2}{*}{$\begin{array}{c}8,16,19,26,28,32,39,57,58,60,61,63,7 \\
0,73,74,80,94,97,105,107,109,112,10 \\
1,111\end{array}$} & AB232806.1 & Bactéria não cultivada & $99 \%$ & Shigematsu et al., 2006 \\
\hline & FN550769.1 & Bactéria não cultivada & $99 \%$ & Cornish Shartau et al., 2010 \\
\hline
\end{tabular}



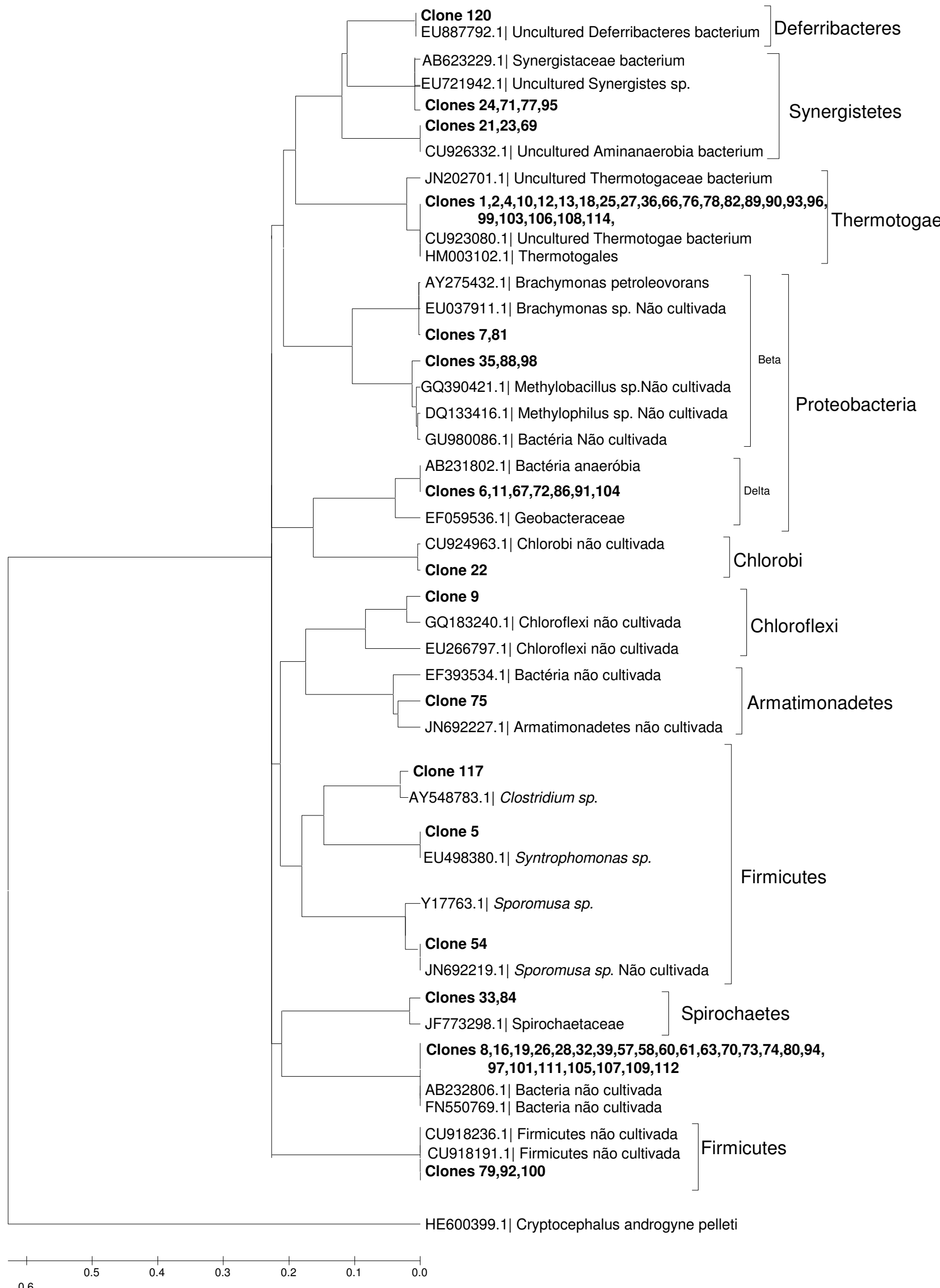

Figura 5-3. Árvore Filogenética de consenso dos clones obtidos a partir da amostra do biofilme do RAHLF para Domínio Bacteria baseado na análise comparativa da sequência do gene RNAr 16S - calculado de acordo com o método Neighbor-joining. Os valores presentes nos nós da árvore indicam a porcentagem que o ramo se repetiu (500 reamostragens de bootstraps). Foi acrescentada seqüência de Cryptocephalus androgyne como out group. 
Dois clones foram relacionados à família Spirochaetaceae $(97 \%$ de similaridade), pertencente ao filo Spirochaetes, classe Spirochaetia e ordem Spirochaetales. Esta família é composta por bactérias anaeróbias estritas ou facultativas, capazes de utilizar carboidratos e aminoácidos como fonte de carbono e energia (GARRITY e HOLT, 2001). O filo Spirochaetes foi encontrado por Rossetti e colaboradores (2003) em cultura enriquecida com tetracloroeteno, o qual foi metabolizado em cloreto de vinila. A família Spirochaetaceae foi identificada em lodo contaminado com petróleo e seus derivados (DAS et al., Não publicado). Dollhopf et al. (2001) cultivaram representantes de Spirochaetaceae em biorreatores metanogênicos. Os autores identificaram que a adição de acetato e etanol como fontes de carbono favoreceram o crescimento destas bactérias. Assim, no presente trabalho, a adição de etanol como fonte de carbono no reator RAHLF, provavelmente, favoreceu a presença destes microrganismos, além dos compostos derivados do petróleo, tais como, os hidrocarbonetos que faziam parte da constituição do ascarel e, por conseguinte da água residuária sintética. Além disso, Correa (2011) também indentificou representantes desta família em amostra desse mesmo reator RAHLF, confirmando, portanto sua presença no biolfime aderido a espuma de poliuretano.

Sete clones foram semelhantes ao Filo Synergistetes. Nesse filo estão incluídas as bactérias anaeróbias, Gram-negativas, em forma de bacilos (JUMAS-BILAK, et al. 2009). Essas bactérias foram identificadas também em sistemas de tratamento de água residuária, solos e poços de petróleo (JUMAS-BILAK, et al. 2009). Tais bactérias possuem a capacidade de degradar aminoácidos e fornecer ácidos graxos de cadeia curta para as arquéias metanogênicas (VARTOUKIAN et al., 2007). Riviére e colaboradores (2009) identificaram alguns destes representantes em reator anaeróbio usado no tratamento de indústria farmaceutica. Além disso, representantes desse filo foram 
obtidos a partir de amostra proveniente de ambiente hidrotermal com redução de óxido de Fe(III) (NEPOMNYASHAYA et al., 2010).

Mais especificamente, quatro clones foram semelhantes a Synergistes (98\% de similaridade), pertencente à familia Synergistaceae, ordem Synergistales e classe Synergistales (filo Synergistetes). Pham et al. (2009) encontraram representantes desse gênero em amostra ambiental degradando ácido carboxilíco de cadeia longa (componentes do petróleo) produzindo acetato. A presença destes microrganismos no presente trabalho é justificada pela disponibilização de ascarel, um óleo resultante da mistura de hidrocarbonetos derivados de petróleo, presente na alimentação do reator. Bem como, compostos de ferro presente na solução metais traços utilizado na alimentação do reator. Além disso, estes microrganismos podem disponibilizar e fornecer ácidos graxos de cadeia curta para as arquéias metanogênicas, como Methanolinea sp. identificada no reator RAHLF por Correa (2011).

Um clone identificado neste trabalho foi relacionado ao filo Deferribacteres (98\% de similaridade). Todos os membros do filo proposto Deferribacteres, relatados até o momento, são caracterizados por serem anaeróbios obrigatórios (GARRITY e HOLT, 2001; GANESAN et al., 2008). Seus representantes respiram anaerobiamente utilizando como aceptores finais de elétrons: $\mathrm{Fe}(\mathrm{III}), \mathrm{Mn}(\mathrm{IV}), \mathrm{S}^{\circ}, \mathrm{Co}(\mathrm{III})$ e nitrato. Provavelmente, os representantes desse filo podem ser originários do inóculo, ou seja, de reator UASB usado no tratamento de água residuária de avicultura foram favorecidos devido as características da água residuária sintética, uma vez que, tais bactérias crescem preferencialmente na presença de proteínas e aminoácidos (GARRITY e HOLT, 2001). Ou seja, mesmo após 180 dias de operação do RAHLF com água residuária distinta essas bactérias mantiveram-se no sistema, provavelmente, usando 
compostos provenientes da própria degradação da biomassa anaeróbia e do ferro disponibilizado na alimentação.

No presente trabalho foram encontrados 23 clones relacionados à família Thermotogaceae (98\% de similaridade). Esta família pertence ao filo Thermogae representado por uma única classe (Thermogae) e ordem (Thermotogales). O filo Thermotogae é composto por bactérias em forma de bacilos com protuberâncias terminais, termófilos ou hipertemófilos, não formadores de endósporos e Gramnegativas. Seus representantes são fermentativos (GARRITY e HOLT, 2001). Além disso, crescimento de bactérias pertencentes a esta família já foi verificado em depósito continental de petróleo e em fluído de plataforma de extração de petróleo, ambos sob temperaturas elevadas (JEANTHON et al., 1995; DIPIPPO et al., 2009).

Entretanto, representantes da ordem Thermotogales foram encontrados em amostras provenientes de locais contaminados com hidrocarbonetos (reservatórios de petróleo) em temperaturas mesófilas e incubadas, posteriormente, em temperaturas inferiores a $46^{\circ} \mathrm{C}$ (NESBO, et al., 2010). Assim, a presença de bactérias pertencentes a essa família no reator RAHLF pode ser explicada pela tolerância de algumas espécies a temperaturas mesófilas, já que o reator foi mantido a $30{ }^{\circ} \mathrm{C}$. A presença de ascarel, ou seja, de hidrocarbonetos provenientes do petróleo na alimentação do reator pode ter favorecido representantes desta família. Além disso, Correa (2011) também indentificou representantes desta família nesse mesmo reator RAHLF.

Também, foram encontrados neste estudo, dois clones relacionados com Brachymonas petroleovorans $(100 \%$ de similaridade) pertencente a família Comamonadaceae, ordem Burkholderiales e classe Betaproteobacteria (filo Proteobacteria). Os representantes deste gênero possuem células em forma de cocos ou 
bacilos, com extremidades arredondadas, ocorrendo isoladamente, em pares ou em cadeias, mesófilos, Gram-negativos, não formadores de endósporos e crescem em condição anaeróbia em meio mineral suplementado com compostos orgânicos simples como doadores de elétrons e fontes de carbono (GARRITY e HOLT, 2001). Membros da família Comamonadaceae foram isolados do solo, lama, água de ambiente natural e residuárias (DE VOS e DE LEY, 1983; DE VOS et al., 1985; WILLEMS et al., 1991). Representantes do gênero Brachymonas foram isoladas de sítios contaminados com pesticidas clorados na Índia (MANICKAM et al., 2010). Além disso, B. petroleovorans foi isolada de estação de tratamento de refinaria de petróleo e caracterizada como degradadora de ciclohexano (PIERRE e MARIO, 2003; ROUVIERE e CHEN, Não publicado). A presença de hidrocarbonetos na composição do óleo ascarel, usado na alimentação, pode ter favorecido o crescimento dessas bactérias no reator RAHLF do presente trabalho.

Três clones foram similares a Methylobacillus (98\% de similaridade), pertencente a família Methylophilaceae, ordem Methylophilales e classe Betaproteobacteria. Refere-se a bactérias Gram-negativas em forma de bacilos móveis por meio de único flagelo polar. A maioria das cepas são metilotróficas obrigatórias e crescem preferencialmente na presença de compostos de um carbono (GARRITY e HOLT, 2001). Algumas cepas foram encontradas na presença de hidrocarbonetos de petróleo (HANSON e HANSON, 1996). Kapley e Purohit (Não publicado) encontraram microrganismos semelhantes a este em estação de tratamento de resíduos nitrosos e compostos aromáticos clorados. Provavelmente, essas bactérias foram favorecidas, devido a composição da água residuária sintética contendo ascarel (anéis aromáticos clorados) e metanol no presente reator. Além de compostos produzidos no processo fermentativo/metanogênico do reator, tais como metano e dióxido de carbono. A 
presença de compostos contendo um carbono é a condição preferencial para essas bactérias.

Sete clones foram pertencentes a Classe Deltaproteobacteria, Ordem Desulfuromonadales, mais especificamente com a Família Geobacteraceae (94\% de similaridade). Referem-se a bactérias Gram-negativas não formadoras de endósporos (BOONE et al., 2005). A ordem Desulfuromonales compreende células na forma de bacilos usualmente móveis. São estritamente quimiolitoheterotróficos ou quimiorganotróficos anaeróbios com metabolismo respiratório ou fermentativo. Todos os membros são mesofílicos com temperatura ótima para crescimento por volta de $30^{\circ} \mathrm{C}$ (GARRITY e HOLT, 2001). A maioria dos membros da família Geobacteraceae pode usar composto férrico como receptor de elétrons. Compostos orgânicos simples, tais como ácido acético e outros ácidos carboxílicos podem servir como doadores de elétrons e fontes de carbono (GARRITY e HOLT, 2001).

A família Geobacteraceae reúne bactérias ferro-redutoras que têm sido encontradas na presença de PCE (tetracloroetileno) e TCE (tricloroetileno) (DUHAMEL e EDWARDS, 2006) e podem oxidar compostos aromáticos (GARRITY e HOLT, 2001), etanol (CHEN et al., Não publicado), tolueno (KUEVER et al., 2005) e bifenilas policloradas (BEDARD, 2008). A presença dessa família pode estar associada, tanto ao uso de etanol, quanto dos compostos aromáticos provenientes do ascarel e do ferro, adicionados na alimentação do reator. Ademais, a presença desse gênero nos trabalhos citados acima, demonstra a capacidade desses microrganismos sobreviverem em condições adversas.

Um clone foi similar ao filo Chlorobi (98\% de similaridade). Até o momento o filo contém única classe (Chlorobia), ordem (Chlorobiales) e família (Chlorobiaceae). 
Todos os representantes possuem coloração Gram-negativa, são anaeróbios estritos, obrigatoriamente fototróficos. As células crescem preferencialmente por fotoassimilação de compostos orgânicos simples. Todos os gêneros são potencialmente mixotróficos (capaz de produzir seu próprio alimento a partir da fixação de $\mathrm{CO}_{2}$, por meio de fotossíntese ou quimiossíntese, podendo também utilizar outros compostos orgânicos ou inorgânicos) e fotoassimilam uma série de substratos orgânicos simples na presença, tanto, de sulfeto como de bicarbonato (GARRITY e HOLT, 2001).

No filo Chlorobi estão incluídas bactérias verdes sulfurosas que oxidam $\mathrm{Fe}^{2+}$ (BRYANT e FRIGAARD, 2006). Provavelmente, a presença de tais bactérias tenha sido favorecida devido à composição do meio Angelidaki (CORREA, 2011) utilizado na alimentação do RAHLF, como bicarbonato, fontes de carbono de fácil assimilação (etanol e formiato), bem como cloreto ferroso tetra hidratado.

Um clone foi similar ao Filo Chloroflexi (97\% de similaridade), o qual engloba bactérias Gram-negativas em forma de filamentos que exibem motilidade por deslizamento. A membrana externa não contém lipopolissacarídeo. Este filo é uma linhagem com profundas ramificações do domínio Bacteria (GARRITY e HOLT, 2001). Moe e colaboradores (2009) conseguiram identificar um novo gênero deste filo capaz de redutivamente desalogenar alcanos alifáticos policlorados, utilizando hidrogênio como doador de elétrons. Maymo-Gatell e colaboradores (1999) evidenciaram que alguns membros deste filo foram capazes de desclorar redutivamente tetracloroeteno, utilizando $\mathrm{H}_{2}$ como doador de elétrons. Winderl et al. (2008) encontraram bactérias semelhantes a estas na presença de tolueno em zona aquífera contaminada com petróleo. Estas bactérias também foram encontradas em meio contendo compostos oleoginosos realizando fotossíntese anoxigênica (BRYANT e FRIGAARD, 2006). 
O filo Chloroflexi foi identificado como a primeira bactéria redutora de PCB em estudos com sedimentos (CUTTER et al., 1998; WATTS et al., 2001;). Fagervolt et al. (2007) estudaram a redução de PCB em sedimento, com a adição de $50 \mathrm{mg} / \mathrm{L}$ de aroclor 1260 e acetato, butirato e proprianato como fontes de carbono. Neste estudo foram identificadas espécies de Chloroflexi, provavelmente, responsáveis pela redução do PCB. Em relação ao presente estudo, tais bactérias foram favorecidas devido a presença do ascarel (PCB) na alimentação do reator.

Um clone foi similar ao filo Armatimonadetes (95\% de similaridade), originalmente conhecido como divisão OP10 (TAMAKI et al., 2011). Informações a respeito de organismos pertencentes a esse filo são escassas na literatura, todavia, alguns representantes foram encontrados a partir da clonagem e sequenciamento de amostra proveniente de sistema de lodos ativados (DALEVI et al., 2001). Além disso, este grupo foi encontrado por D'Angelo e NUNEZ (2010) em pesquisa que evidenciou a redução de bifenilas policloradas em sedimento de rio, enriquecidos com 245-2'4'5' hexaclorobifenil e incubados na presença de $\mathrm{FeSO}_{4}$. D'Angelo e Nunez (2007) verificaram microrganismos semelhantes a estes na caracterização do consórcio microbiano responsável pela descloração de bifenilas policloradas em condição anaeróbia.

Representantes do filo Armatimonadetes, também foram identificados em reator anaeróbio utilizado no tratamento de água residuária contendo o surfactante alquilbenzeno linear sulfonado (DELFORNO et al., 2012) inoculado com a mesma biomassa utilizada para inocular o reator RAHLF deste trabalho. Desta forma a presença deste grupo no reator ainda se apresenta subjetiva, entretanto, tal bactéria, possivelmente, estava presente no lodo anaeróbio usado como inóculo no reator e 
encontrou ambiente favorável para se manter no biofilme. A disponibilidade de ferro, bem como de PCB, podem ter favorecido o crescimento deste microrganismo.

Seis clones foram relacionados ao filo Firmicutes (99\% de similaridade). Este filo reúne procariotos com a parede celular geralmente Gram-positiva, não são fotossintéticos e em geral são heterotróficos quimiossintetizantes e incluem grupos aeróbios, anaeróbios e anaeróbios facultativos (GARRITY e HOLT, 2001). Microrganismos pertencentes a este filo são comumente encontrados em reatores anaeróbios (RIVIERE et al., 2009). Estes microrganismos podem utilizar ácidos orgânicos voláteis com produção de $\mathrm{H}_{2}$, estabelecendo relação sintrófica com arquéias metanogênicas hidrogenotróficas. Assim, sua presença no presente estudo pode estar associada a disponibilização de ácidos orgânicos no reator como formiato e etanol (fonte de carbono adicionada no meio). Além disso, estes microrganismos podem disponibilizar hidrogênio para as arquéias metanogênicas hidrogenotróficas, como Methanolinea sp., encontrada no reator RAHLF por Correa (2011).

Um clone foi similar a Clostridium (97\% de similaridade), pertencente á família Clostridiaceae, ordem Clostridiales e classe Clostridia (filo Firmicutes). Neste gênero estão incluídasbactérias em forma de bacilos, geralmente possuem coloração Gram-positiva (GARRITY e HOLT, 2001). Representantes deste gênero produzem misturas de ácidos orgânicos e álcoois e são capazes de metabolizar carboidratos, álcoois e outros compostos orgânicos. A maioria das espécies são anaeróbias estritas, embora a tolerância ao oxigênio varie muito (GARRITY e HOLT, 2001). Hou e Dutta (2000) estudaram amostras de sedimento contaminado com PCB do lago Medinah (Nova York). Os autores confirmaram que diferentes espécies deste gênero foram capazes de realizar desclorinação de PCB. Sendo assim, os microrganismos encontrados 
no presente trabalho poderiam estar atuando na degradação do PCB, adicionado na forma de ascarel.

Rowe et al. (2008) encontraram bactérias similares a Clostridium em cultura mista removedora de cloro. Neste contexto, a presença destas bactérias neste trabalho pode estar associada a presença de ascarel, que contém ácidos graxos e compostos clorados. Além disso, pode ter sido estabelecida relaçào com as arquéias metanogênicas hidrogenotróficas, como por exemplo, Methanolinea sp., identificada por Correa (2011) no reator RAHLF usado nessa pesquisa.

Um clone foi similar a Syntrophomonas (100\% de similaridade), pertencente a família Syntrophomonadaceae, ordem Clostridiales e classe Clostridia (filo Firmicutes). Os representantes da família Syntrophomonadaceae são anaeróbios estritos e heterótrofos, a maioria oxida anaerobiamente ácidos graxos saturados contendo de 4-18 carbonos na forma linear ou em cadeia ramificada. Além disso, podem estabelecer relação sintrófica arquéias metanogênicas hidrogenotróficas. Essas bactérias estão presentes em ecossistemas anaeróbios, tanto, em sedimento marinho como de água doce, bem como, em digestor de lodo de esgoto, e rúmen (GARRITY e HOLT, 2001).

O último clone foi similar a Sporomusa (100\% de similaridade), pertencente à família Veillonellaceae, ordem Selenomonadales eclasse Negativicutes (filo Firmicutes). Até 2010, esse gênero era classificado como pertencente à ordem Clostridiales e classe Clostridia (MARCHANDIN et al., 2010). Todos os representantes do gênero Sporomusa são anaeróbios estritos, mesófilos e acetogênicos. Seu crescimento pode ocorrer em ambas os processos quimiorganotrófico e quimiolitotrófico (GARRITY e HOLT, 2001). 
Espécies do gênero Sporomusa foram obtidas a partir de variedade de habitats, incluindo silagem (MÖLLER et al, 1984.), intestino de cupins (BOGA et al, 2003; BREZNAK et al, 1988), sedimento de água doce (DEHNING et al, 1989; MÖLLER et al, 1984), solo aerado (KUHNER et al, 1997) e raízes de plantas estuarinas (GÖßNER et al, 2006b). Formiato, $\mathrm{H}_{2} / \mathrm{CO}_{2}$, metanol, entre outros, são os substratos comumente utilizados por este gênero. Várias espécies têm a capacidade de utilizar grupos metoxila $\left(-\mathrm{OCH}_{3}\right)$ de compostos aromáticos, além de tolerar e consumir (isto é, reduzir) pequenas quantidades de $\mathrm{O}_{2}$ (GÖßNER et al., 2004). Sua presença no reator pode estar associada a presença de formiato e metanol, o qual foi utilizado, provavelmente, como fonte de carbono.

Por meio das análises filogenéticas realizadas no reator anaeróbio operado na presença de ascarel (1 mL/L), alimentado com meio Angelidaki e biomassa imobilizada em espuma de poliuretano foi possível relacionar a presença de bactérias capazes de utilizar compostos aromáticos e outras, metabolizar compostos clorados. Representantes do filo Chloroflexi realizam a remoção de cloro do PCB, portanto, provavelmente, responsáveis pela utilização do ascarel. Alguns clones ainda foram relacionados com bactérias redutoras de ferro (Deferribacteres e Geobacteriaceae), justificando, assim, as próximas etapas do trabalho, como a quantificação destas bactérias e a análise do crescimento destas bactérias na presença de PCB sob forma de aroclor 1260.

\subsubsection{Técnica dos tubos múltiplos}

O biofilme amarelado proveniente do reator RAHLF operado por Correa (2011) e alimentado com ascarel e meio de cultura Angelidaki foi utilizado para estimar a população de bactérias redutoras de ferro. Assim, após período de incubação (30 dias a $30^{\circ} \mathrm{C}$ ), os frascos, em triplicata para diluições de $10^{-1}$ a $10^{-21}$, foram analisados (Figura 
5-4) para verificar o crescimento de bactérias redutoras de ferro cujo valor obtido foi de $5,26 \times 10^{12} \mathrm{NMP} / \mathrm{g}$ STV.

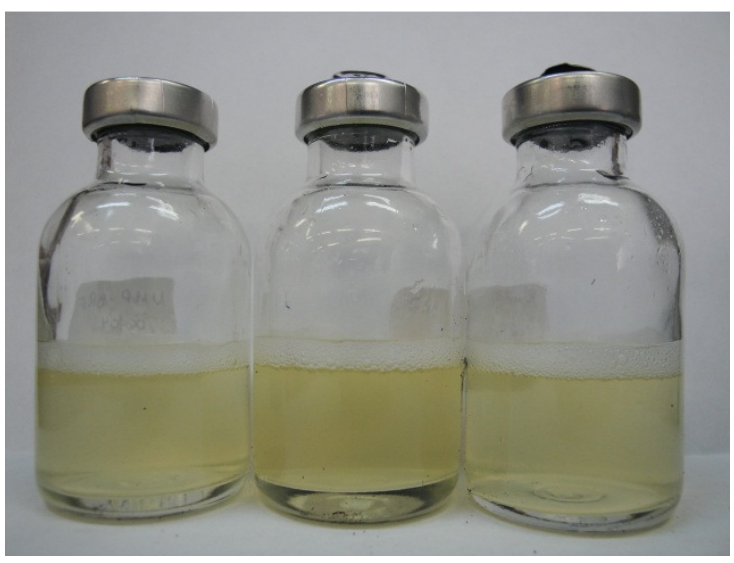

(a)

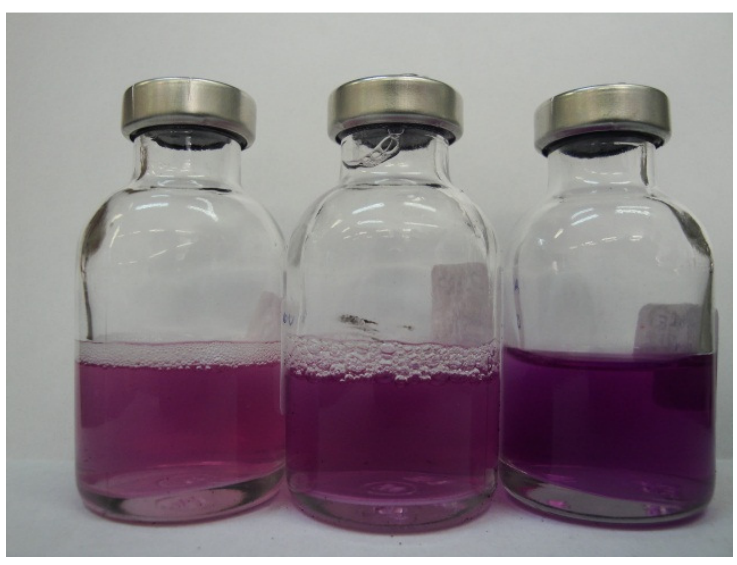

(b)

Figura 5-4. Frasco de contagem de NMP para bactérias redutoras de ferro: (a) tubos negativos; (b) tubos positivos

Delforno (2011) avaliou a remoção de LAS (alquibenzeno linear sulfonado) em reator EGSB (Expanded Granular Sludge Bed) utilizando o mesmo inóculo e meio de cultura (ANGELIDAKI et al. 1990) usado nessa pesquisa. O autor obteve 2,1 1 10 ${ }^{9} \mathrm{NMP} / \mathrm{gSTV}$. Esta diferença pode ser explicada pela distinta configuração dos reatores em cada estudo, bem como, os compostos tóxicos adicionados. Entretanto, em ambos os casos, a composição de nutrientes do meio Angelidaki, provavelmente, favoreceu o crescimento das BRFs. Destaca-se ainda que o inóculo usado no reator RAHLF, caracterizado nesse trabalho foi proveniente de reator UASB usado no tratamento de água residuária de avicultuta. Nesta água, provavelmente, é encontrado alta concentração de ferro devido a presença de sangue proveniente do abatedouro das aves, portanto, sustentando a presença destas bactérias.

Petrie e colaboradores (2003) obtiveram $1,58 \times 10^{7} \mathrm{NMP} / \mathrm{mL} \quad$ a 8,33x $10^{7} \mathrm{NMP} / \mathrm{mL}$ de BRFs em solo contaminado com urânio. Em análise comparativa, 
nesse trabalho, com adição de PCB (ascarel) obteve-se $1,5 \times 10^{11} \mathrm{NMP} / \mathrm{mL}$. O menor valor obtido por Petrie e colaboradores (2003) foi decorrente da alta toxicidade do urânio.

Devido a quantificação elevada das bactérias redutoras de ferro no biofilme retirado do reator RAHLF (Correa, 2011) operado em condição fermentativametanogênica, foi proposto ensaio em reatores em batelada com a finalidade de avaliar o desenvolvimento das arquéias metanogênicas e bactérias redutoras de ferro na presença de PCB (aroclor 1260).

\section{$5.2-2^{\mathrm{a}}$ etapa - Reator em Batelada}

Ensaios foram realizados com a finalidade de avaliar o crescimento das bactérias ferro-redutoras e arquéias metanogênicas na presença de PCB (aroclor 1260). Esses ensaios foram realizados em reator anaeróbio em batelada, separadamente, com biomassa imobilizada em espuma de poliuretano. O reator controle metanogênico (M0) foi constituído de biomassa inativada e imobilizada em espuma de poliuretano, meio basal (Angelidaki et al.,), etanol (46 g/L), formiato (680 g/L), bicarbonato, Triton 100x (10\%), e padrão aroclor $1260(2 \mu \mathrm{g} / \mathrm{L})$.

A condição metanogênica (M0, M1, M2 e M3) foi induzida pela inoculação do lodo de avícola, na presença de fontes de carbono (formiato e etanol), meio basal, material suporte e aroclor. O monitoramento contínuo da produção de metano nos reatores em batelada possibilitou a obtenção de dados que correlacionam tempo (t), em horas, e produção cumulativa de metano, em $\mathrm{CH}_{4} / \mathrm{L}$. A avaliação da produção de metano $\left(\mathrm{CH}_{4} \mathrm{~L} / \mathrm{gSVTh}\right)$ foi feita determinando-se a razão entre a taxa máxima de produção de metano $\left(\mathrm{CH}_{4} \mathrm{~L} / \mathrm{h}\right)$, e a quantidade inicial de biomassa (gSVT) (CORREA, 
2011). Após 22,5 horas de operação obteve-se velocidade máxima de $3,8 \times 10^{-4} \mathrm{mmol}$ $\mathrm{CH}_{4} / \mathrm{g}$ STV (Figura 5-5).

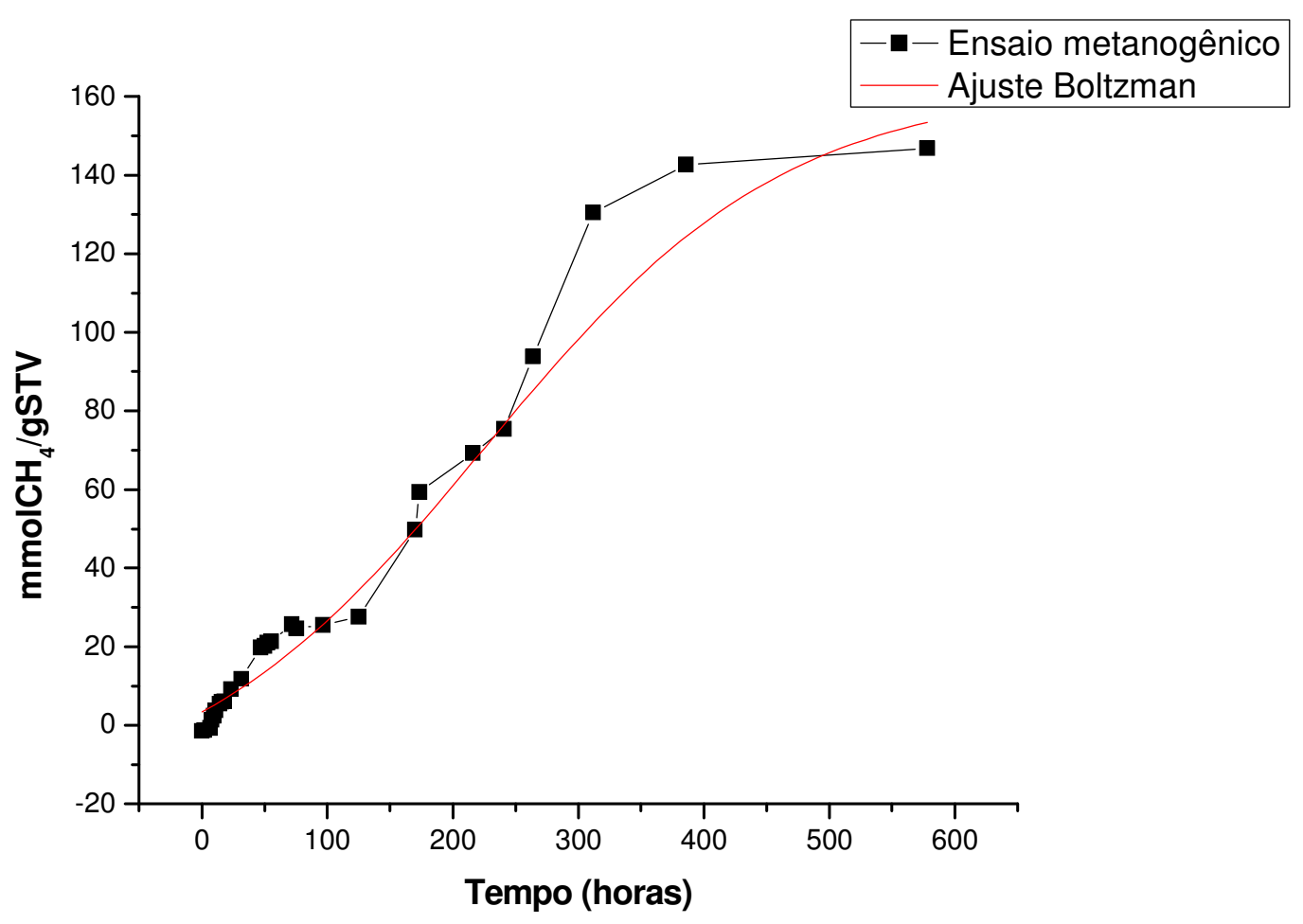

Figura 5-5. Produção média de metano em função do tempo ajustada com a função de Boltzman.

Correa (2011) também avaliou a produção de metano em reatores em batelada alimentado com meio Angelidaki, etanol (46 g/L), formiato (680 g/L), bicarbonato e Triton 100x (10\%), todavia com ascarel. Portanto, a única diferença em relação a esse

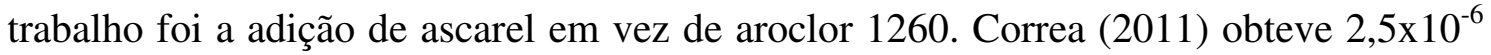
mmol $\mathrm{CH}_{4} / \mathrm{gSTV}$ após 33,4 horas de operação. Essa menor velocidade pode ser atribuída à presença de outros compostos presentes no ascarel, inibindo assim a produção de metano. 
Além disso, quando considera-se somente as primeiras 18 horas deste ensaio obteve-se curva distinta, com velocidade máxima de produção de metano de $10,6 \times 10^{-}$ ${ }^{4} \mathrm{mmol} \mathrm{CH}_{4} / \mathrm{g} \mathrm{STV}$ (Figura 5-6) após 9,46 horas.

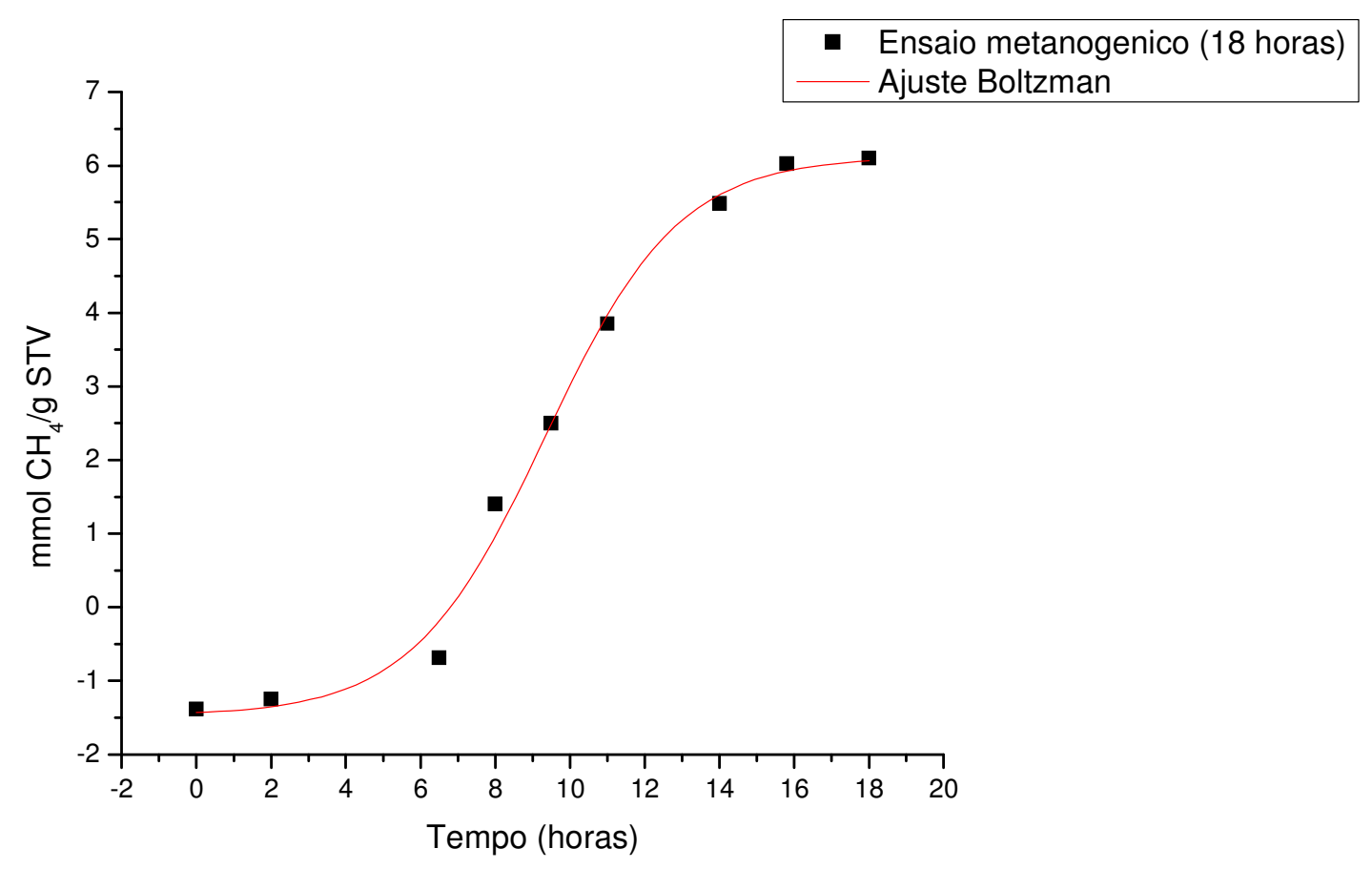

Figura 5-6. Produção média de metano em função do tempo ajustada pela função de Boltzman.

Provavelmente, nesse período de 18 horas ocorreu a utilização de toda fonte de carbono de fácil utilização (formiato e etanol). Portanto, mesmo na presença de PCB, as arquéias metamogênicas cresceram e produziram metano. Deve-se ressaltar que o lodo usado como inóculo é predominantemente metanogênico. Hirasawa (2007) verificaram por meio da técnica de Fish (Fluorescent In Situ Hybridization) predomínio de arquéias metanogênicas $(59,5 \%)$ em relação a bactérias (Domínio Bacteria, 44,8\%) no lodo granulado usado nesse trabalho como inóculo para ensaio em batelada. 
Nos outros reatores (BRF1, BRF2 e BRF3) foi induzida condição redutora de ferro com 1,86g/L de EDTA férrico sal sódico, que continha 5mmol/L de $\mathrm{Fe}(\mathrm{III})$, de acordo com metodologia adaptada de Gould et al. (2002). A adição de EDTA férrico (Fe III) foi alternativa para a alteração da condição fermentativa/metanogênica para ferro redutora (DELFORNO, 2011).

A quantidade de compostos férricos e ferrosos no experimento foi determinada por meio da análise espectrofotométrica de ferro, utilizando como reagente a ferrozina (VIOLLIER et al., 2000).

Tabela 5-2. Concentração de ferro obtido do ensaio em batelada para os reatores BRF1, BRF2 e BRF3

\begin{tabular}{ccccc}
\hline Reator & $\begin{array}{c}\text { Fe II (mmol/L) } \\
\text { Após 60 dias de } \\
\text { operação }\end{array}$ & $\begin{array}{c}\text { Fe III(mmol/L) } \\
\text { Após 60 dias } \\
\text { de } \\
\text { operação }\end{array}$ & $\begin{array}{c}\text { Fe total } \\
\text { (mmol/L) }\end{array}$ & $\begin{array}{c}\text { Taxa de } \\
\text { redução } \\
\text { férrica }\end{array}$ \\
\hline BRF1 & 4,90 & 0,17 & 5,05 & $96 \%$ \\
\hline BRF2 & 4,93 & 0,09 & 5,02 & $98 \%$ \\
\hline BRF3 & 3,80 & 1,18 & 4,98 & $76 \%$ \\
\hline Média & 4,54 & 0,48 & & $90 \%$ \\
\hline
\end{tabular}

A concentração de ferro total obtida para o Reator BRF1, BRF2 e BRF3 foi de 5,05, 5,02 e 4,98 $\mathrm{mmol} / \mathrm{L}$ respectivamente, ou seja, valor próximo aquele adicionado no meio (5mmol/L EDTA férrico).

Levando em consideração a técnica dos tubos múltiplos realizada na $1^{\mathrm{a}}$ etapa, pode-se afirmar que o meio reacional não induziu a redução férrica abiótica, já que o controle no teste de NMP não formou complexo ferrozina-Fe ${ }^{2+}$ e continuou incolor 
(dado não mostrado). Assim, pode-se inferir que a redução férrica nos reatores BRF1, BRF2 e BRF3 (96, 98 e 76\% respectivamente) pode ter sido ocasionada por atividade de bactérias redutoras de ferro. Esta taxa de redução férrica poderia ter sido maior, porém, pode ter sido inibida por adsorção do Fe(III) precipitado (RODEN et al., 2000) ou ainda pelo $\mathrm{Fe}$ (II) depositado na superfície celular, formado como subproduto da redução microbiana de Fe(III) (URRUTIA et al., 1998).

Vale salientar, ainda, que taxa média de $90 \%$ é plausível com a existência de comunidade redutora de ferro, como filo Deferribacteres e Família Geobacteraceae, ambos conhecidamente microrganismos redutores de ferro que estavam presentes no reator RAHLF. Além disso, Bedard et al. (2007) afirmaram que estas bactérias possuem a capacidade de oxidar bifenilas policloradas. Portanto, a redução de ferro no reator em batelada na presença de aroclor 1260 provavelmente ocorreu devido a participação dessas bactérias.

\subsubsection{Análise de PCB}

A concentração de aroclor 1260 utilizada no ensaio esteve inserida entre os pontos extremos da curva, para tanto, estas concentrações extremas foram 0,04 e 0,2 mg/L. Na última etapa foram realizadas as análises das amostras provenientes do ensaio em batelada comparando a presença de PCB em condição metanogênica e redutora de ferro. Como o PCB foi adicionado em concentrações muito baixas, no fator de diluição de 1:1000, não foi possível analisar a concentração final de PCBs, tanto no afluente, como, no efluente. Os picos obtidos nos cromatogramas eram muito baixos, semelhantes a ruídos e não a efetivos picos de PCBs. Portanto, este dado não pode ser analisado e os cromatogramas encontram-se em anexo. 


\subsubsection{Análise de Ácidos Orgânicos Voláteis}

Na Tabela 5-3 estão descritos os resultados dos ácidos voláteis totais do ensaio em batelada, comparando as seguintes condições: (1) reator branco, que continha o meio Angelidaki, fontes de carbono (formiato e etanol) sem biomassa, (2) reatores controle M0 e BRF0, contendo meio Angelidaki, fontes de carbono e biomassa inativada e (3) reatores metanogênico $(\mathrm{M})$ e (4) redutor de ferro (BRF).

Tabela 5-3. Ácidos orgânicos voláteis nos reatores em batelada.

\begin{tabular}{|c|c|c|c|c|c|}
\hline $\begin{array}{c}\text { Concentração } \\
\text { mg/L }\end{array}$ & BRANCO & M0 & $\mathbf{M}$ & BRFO & BRF \\
\hline Málico & $<\mathrm{LD}^{*}$ & 9 & $<\mathrm{LD}^{*}$ & $<\mathrm{LD}^{*}$ & $<\mathrm{LD}^{*}$ \\
\hline Succinico & 14 & 11 & $<\mathrm{LD}^{*}$ & $<\mathrm{LD}^{*}$ & $<\mathrm{LD}^{*}$ \\
\hline Lático & $<\mathrm{LD}^{*}$ & 4 & $<\mathrm{LD}^{*}$ & $<\mathrm{LD}^{*}$ & $<\mathrm{LD}^{*}$ \\
\hline Fórmico & 254 & 245 & $<\mathrm{LD}^{*}$ & 200 & 10,17 \\
\hline Acético & $<\mathrm{LD}^{*}$ & 20 & $<\mathrm{LD}^{*}$ & 2 & $<\mathrm{LD}^{*}$ \\
\hline Propiônico & $<\mathrm{LD}^{*}$ & 12 & 10,79 & $<\mathrm{LD}^{*}$ & 101,09 \\
\hline Isobutírico & $<\mathrm{LD}^{*}$ & 324 & 3,41 & 226 & 84,58 \\
\hline Butírico & $<\mathrm{LD}^{*}$ & $<\mathrm{LD}^{*}$ & $<\mathrm{LD}^{*}$ & $<\mathrm{LD}^{*}$ & 15,42 \\
\hline Isovalérico & $<\mathrm{LD}^{*}$ & 296 & 2,83 & 124 & $<\mathrm{LD} *$ \\
\hline Valérico & $<\mathrm{LD}^{*}$ & 5 & $<\mathrm{LD}^{*}$ & $<\mathrm{LD}^{*}$ & $<\mathrm{LD}^{*}$ \\
\hline Capróico & 14 & 163 & 17,74 & 84 & 1230,31 \\
\hline Etanol & 265 & 278 & $<\mathrm{LD} *$ & 272 & 74,15 \\
\hline
\end{tabular}

*Limite de detecção

Diferenças entre a condição metanogênica e redutora de ferro foram evidenciadas, principalmente, para as concentrações de ácido propiônico, que foi produzido no ensaio redutor de ferro $(101,09 \mathrm{mg} / \mathrm{L})$. As bactérias redutoras de ferro 
podem produzir o ácido propriônico através da oxidação de propanol (FREDRICKSON e GORBY, 1996). O ácido capróico, assim como o cítrico foi consumido no ensaio metanogênico (de 163 para 17,74mg/L) e produzido na condição redutora de ferro (de 84 para $1.230,31 \mathrm{mg} / \mathrm{L})$.

Em um sistema alimentado com etanol como substrato base, Young e Tabak (1993) discutem que a formação de ácido propiônico na presença de PCP é devido a metabólitos intermediários das células, pois não estava presente precursores do ácido propiônico em solução. Entretanto, cabe lembrar que, de acordo com Hirata (1997), ácido propiônico pode ser formado a partir do acetato pela ação de microrganismos. Nos reatores redutores de ferro a concentração do acido acético foi menor $(2 \mathrm{mg} / \mathrm{L})$ do que a apresentada pelos reatores metanogênicos $(20 \mathrm{mg} / \mathrm{L})$ indicando uma possível formação de ácido propriônico via acetato. Os ácidos isobutírico e isovalérico podem ser provindos do lodo utilizado na inoculação dos reatores, pois não foi detectado no reator branco, que não continha lodo, e foi detectado na condição metanogênica e na condição redutora de ferro.

As fontes de carbono adicionadas tanto no meio metanogênico como redutor de ferro foram ácido fórmico e etanol. O etanol foi utilizado no meio sob condição metangênica (de 278mg/L para abaixo do limite de detecção) bem como no meio redutor de ferro (de 272 para 74,15 mg/L). O ácido fórmico também foi utilizado no reator metanogênico ( $245 \mathrm{mg} / \mathrm{L}$ para abaixo do limite de detecção) e no reator redutor de ferro (200 para 10,17 mg/L). Estes resultados comprovam que em ambas as condições estas fontes de carbono foram devidamente elegidas. 


\subsubsection{Exames Microscópicos}

Ao final do ensaio em batelada as amostras foram analisadas em microscópio óptico de contraste de fase. Desse modo, constatou-se a presença no ensaio sob condição metanogênica de morfologias semelhantes à Methanosaeta, Methanosarcina, cocos e bacilos (Figura 5-7).

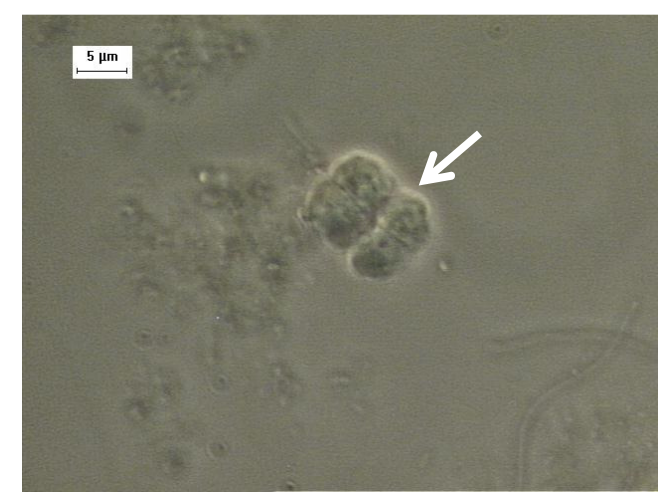

(a)

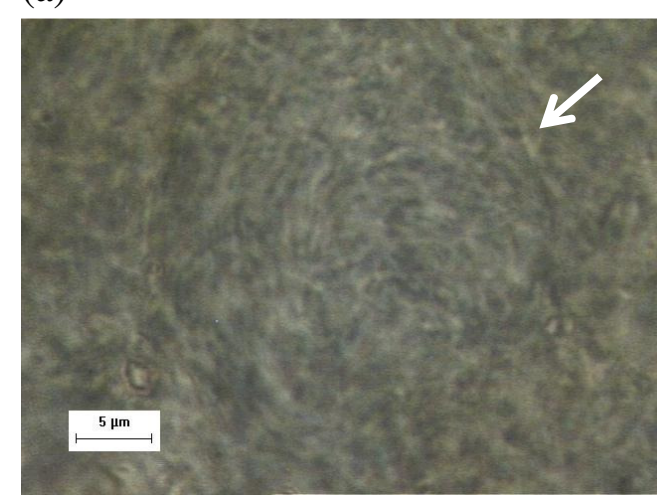

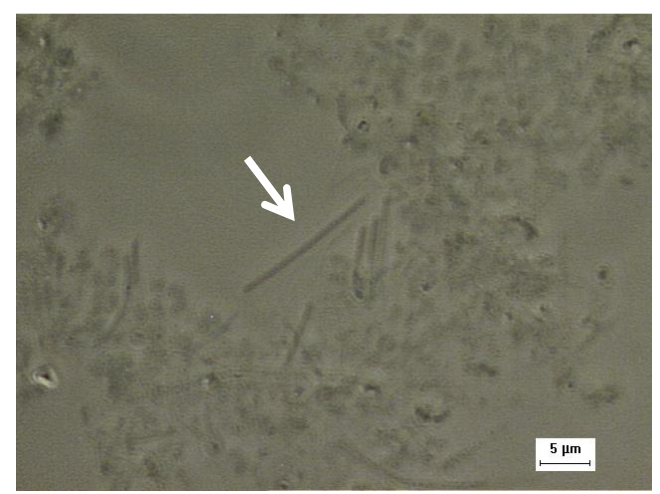

(b)

(c)

Figura 5-7. Morfologias observadas em microscópio óptico (1000X): (a) Morfologia característica de Methanosarcina (b) Filamentos sem grânulos característicos de Methanosaeta (c) Arranjo em forma de digital característico de bacilos.

Nas amostras dos reatores metanogênicos foi observado diversidade de morfologias semelhantes a arquéias metanogênicas acetoclásticas (Methanosaeta sp. e Methanosarcina sp.). Methanosaeta possui estrutura típica de células rodeadas por bainha tubular. Tais arquéias utilizam somente acetato como fonte de carbono (GARRITY e HOLT, 2001), enquanto, Methanosarcina pode usar metanol, acetato, 
$\mathrm{H}_{2} / \mathrm{CO}_{2}$ e metilaminas como fonte de carbono (GARRITY e HOLT, 2001). No ensaio sob condição redutora de ferro foi constatado a presença de morfologias semelhantes a bacilos (Figura 5-8).

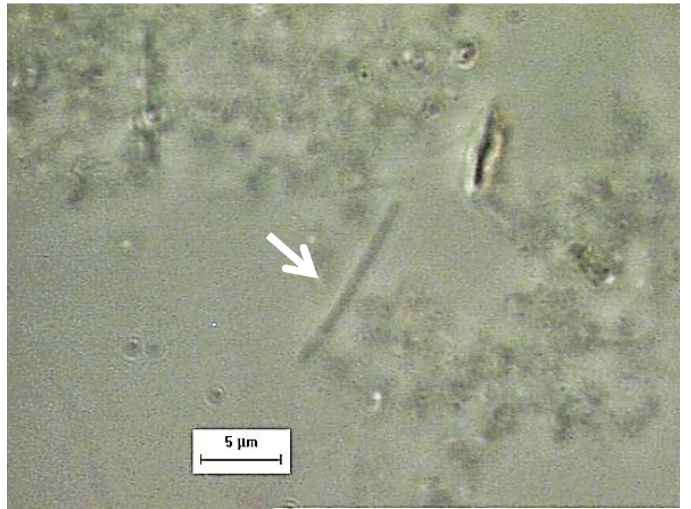

(a)

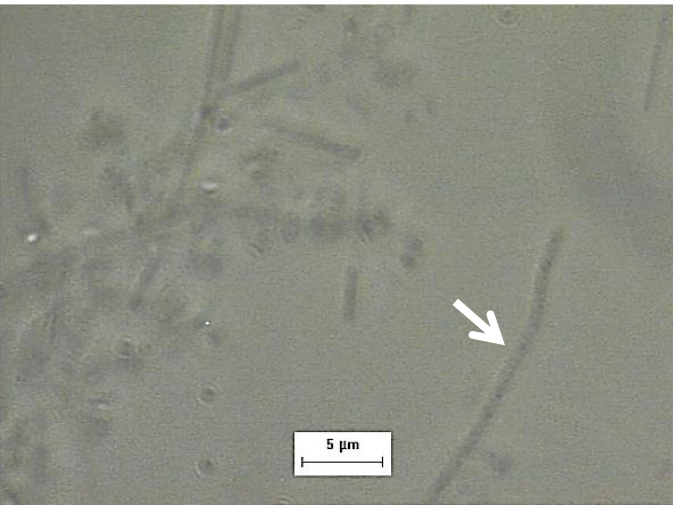

(b)

Figura 5-8. Morfologias observadas em microscópio óptico (1000X) da condição redutora de ferro: (a) Bacilos, (b) Filamentos com grânulos que podem representar o armaenamento de ferro dentro da célula.

A precipitação microbiana do hidróxido férrico é comum na natureza. Análises de microscopia eletrônica de transmissão comumente indicam que células bacterianas se localizam parcialmente oucompletamente dentro de matrizes extracelular ricas em ferro ou com ferro intracelular precipitado (KONHAUSER, 1998). Há vários exemplos bem documentados de bactérias ferro redutoras que formam um depósito natural de ferro em sistemas aquáticos, tais como Sphaerotilus, Leptothrix, Crenothrix, Clonothrix e Hyphomicrobium spp., que se ligam e precipitam composto férrico passivamente na superfície de sua célula (GHIORSE, 1984; GHIORSE e EHRLICH, 1992). Neste contexto, as amostras dos reatores em condição redutora de ferro apresentaram bacilos que continham pequenos grânulos escuros internamente (Figura 5-8 b), que podem ser classificados como precipitado férrico. 


\subsubsection{Eletroforese Em Gel Com Gradiente Desnaturante}

Sabe-se que a técnica do DGGE é adequada para acompanhar a dinâmica de populações específicas em função de variações ambientais ou das condições operacionais de um sistema (SANZ, 2002). Assim, foi utilizada esta técnica para avaliar a diversidade microbiana em diferentes configurações de reator (RAHLF e batelada), bem como, diferentes fontes de PCB (ascarel e padrão Aroclor 1260, respectivamente).

Com os produtos de PCR das diferentes amostras, foram realizadas análises pela técnica de eletroforese em gel com gradiente desnaturante (DGGE) para verificar a ocorrência de alterações na comunidade microbiana pertencente aos Domínios Bacteria e Archaea do inóculo, do reator RAHLF e dos reatores em batelada. A partir do DGGE realizado com os primers para o Domínio Bacteria dos ensaios em batelada, das amostras retiradas do reator RAHLF (CORREA, 2011) e do inóculo foi elaborado um dendograma (Figura 5-9).

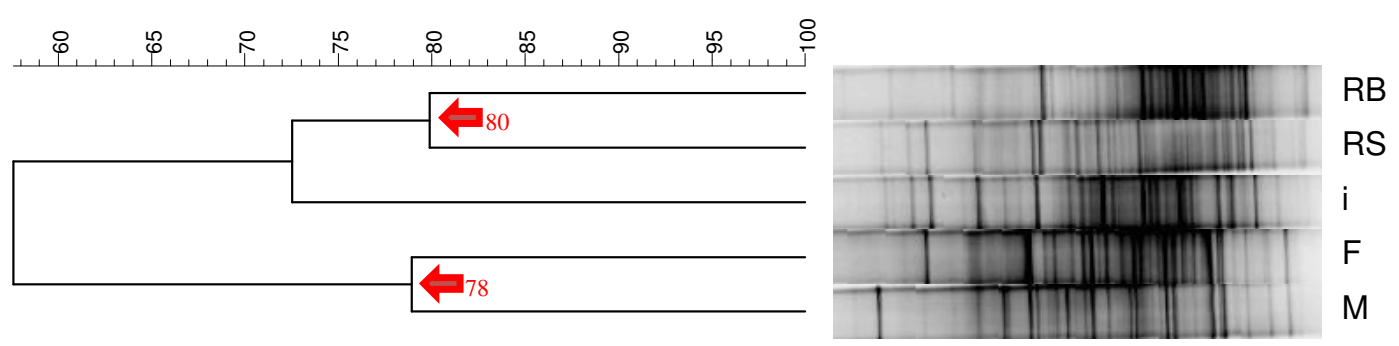

Figura 5-9. Dendograma com primers para o Domínio Bacteria, correlação de Pearson. $\mathrm{RB}=$ biofilme da parede do reator RAHLF; RS=biofilme aderida no material suporte; $\mathrm{F}=$ ensaio em batelada/condição redutora de ferro; $\mathrm{M}=$ ensaio em batelada/condição metanogênica; i=inóculo.

Desse modo foi possível observar dois agrupamentos principais de similaridade maior que $75 \%$. No primeiro agrupamento com $80 \%$ de similaridade verificou-se a 
presença das amostras do reator RB e RS, provenientes respectivamente do biofilme que se originou na parede do reator onde a maior parte do óleo ficou depositada, e do biofilme que ficou aderida ao material suporte. $O$ segundo agrupamento com similaridade de $78 \%$ reuniu amostras do ensaio em batelada na condição metanogênica (M) e condição redutora de ferro (F). O inóculo se aproximou mais das amostras retiradas do reator RAHLF (RB e RS) com $72 \%$ de similaridade.

Do mesmo modo, o dendograma realizado a partir do DGGE com os primers para o Domínio Archaea (Figura 5-10) também foi possível observar dois agrupamentos principais (similaridade maior que 90\%). No primeiro agrupamento relacionaram-se as amostras do reator, RB e RS (biofilme na parede do reator e biofilme que ficou aderido ao material suporte, respectivamente) com $95 \%$ de similaridade. No segundo agrupamento também reuniu amostras do ensaio em batelada (condição metanogênica M- e condição redutora de ferro -F-), cujo valor de similaridade foi de 92,5\%. O inóculo novamente se mostrou a amostra mais distante filogeneticamente com $80 \%$ de similaridade.

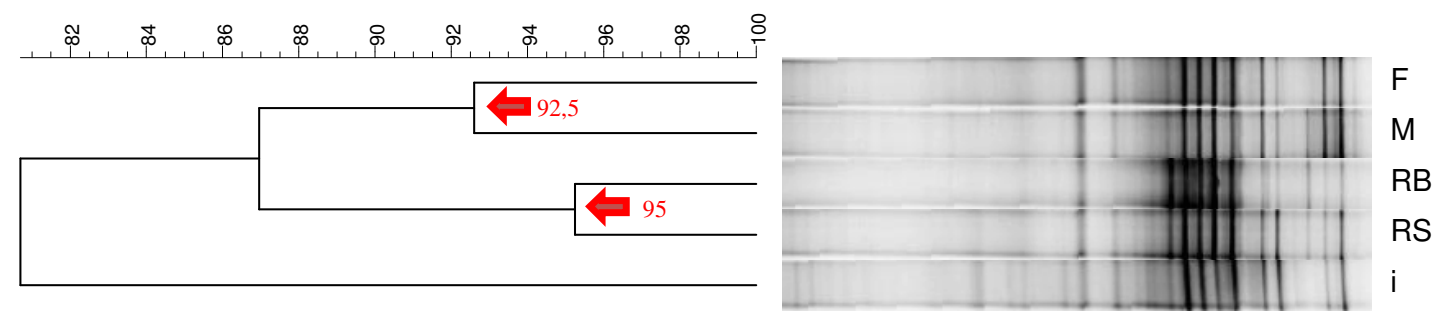

Figura 5-10. Dendograma com primers para o Domínio Archaea, correlação de Pearson. $\mathrm{RB}=$ biofilme da parede do reator RAHLF; RS=biofilme aderida no material suporte; $\mathrm{F}=$ ensaio em batelada/condição redutora de ferro; $\mathrm{M}=$ ensaio em batelada/condição metanogênica; i=inóculo.

Avaliando o perfil de bandas padrões do DGGE realizado com os primers tanto para o domínio Bacteria quanto para o domínio Archaea observou-se maior 
similaridade entre as amostras do reator RAHLF, bem como, entre as amostras do ensaio em batelada. Neste contexto os resultados de DGGE através do dendograma mostram que a comunidade microbiana anaeróbia desenvolvida no biofilme do RAHLF com ascarel foi distinta daquela alimentada com o padrão aroclor 1260. Bedard e colaboradores (2007) afirmaram que aroclor, especialmente as misturas altamente cloradas como aroclor 1260, são de dificil biodegradação. Estas misturas complexas consistem de dezenas de congêneres, indicando que a utilização deste composto selecionou a comunidade distinta daquela selecionada com a utilização do composto ascarel. Contudo, as distintas configurações dos reatores também podem ter sido mais significativas para a seleção das comunidades microbianas do que a condição estabelecida (nos ensaios em batelada: metanogênico e redutor de ferro). Outro fator importante foi o tempo de operação de cada reator. O ensaio em batelada foi operado por 60 dias, já o RAHLF por 180 dias, o que já conferiria por si só a seleção da comunidade similar entre os reatores em batelada e entre as amostras do RAHLF.

Além disso, vários estudos têm mostrado que a produção de metano é severamente inibida sob condições redutoras de ferro (ACHTNICH et al., 1995; BODEGOM e STAMS, 1999). Esta inibição é geralmente explicada pela concorrência das arquéias metanogênicas e das bactérias redutoras de ferro pelo substrato, como o acetato e o hidrogênio. Contudo, somente esta concorrencia não pode explicar a forte inibição da metanogênese durante a redução de Fe(III) (VAN BODEGOM et al., 2004). Além disso, investigações anteriores demonstraram que arquéias metanogênicas podem transferir elétrons para outras vias metabólicas além da metanogênese, por exemplo, para reduzir o enxofre molecular (STETTER e GAAG, 1983), substâncias húmicas (CERVANTES et al., 2002) e Fe(III) (BOND e LOVLEY, 2002). Coletivamente, esses estudos sugerem que além da competição pelo substrato, algum outro fator desempenha 
papel importante na inibição da metanogênese durante a redução $\mathrm{Fe}(\mathrm{III})$ (VAN BODEGOM et al., 2004). Neste contexto a similaridade acima de $75 \%$ entre os ensaios em batelada tanto na condição ferro redutora quanto na condição metonogênica pode ser explicada pela versatilidade das arquéias metanogênicas, que na presença do composto férrico podem ter mudado seu metabolismo e utilizado rota alternativa, mantendo-se no sistema.

Como pode ser verificado, as diferenças entre a comunidade microbiana do reator RAHLF e do ensaio em batelada, tanto para o Domínio Archaea quanto para o Bacteria, sugerem que as condições do reator e de PCB adicionado favoreceram maior semelhança dentro dos reatores do que entre as condições estabelecidas. 
“Agradeço todas as dificuldades que enfrentei não fosse por elas, eu não teria saído do lugar. As facilidades nos impedem de caminhar. Mesmo as críticas nos auxiliam muito."

Chico Xavier 


\section{CONCLUSÕES}

PPor meio das análises das sequencias do fragmento do gene RNAr 16S do reator RAHLF foi possível constatar grande diversidade microbiana com organismos pertencenentes aos Filos Thermogae, Proteobacteria, Firmicutes, Synegistetes, Spirochaetes, Aminanaerobia, Chloroflexi, Chlorobi, Deferribacteres e Armatimonadetes.

-Grupos microbianos, tais como Chloroflexi e Armatimonadetes, que estão relacionados a degradação de PCB, foram encontrados no RAHLF, evidenciando possível degradação de PCB no reator.

OAtravés da técnica de tubos múltiplos pode-se concluir que houve alta concentração das bactérias redutoras de ferro no RAHLF, mesmo em presença de compostos tóxicos como o ascarel. Assim inferindo sobre a possibilidade de degradação do PCB por meio destas bactérias.

ЭA concentração baixa de PCB $(0,5 \mathrm{~mL} / \mathrm{L})$ adicionada nos reatores em batelada não foi adequada para o método de extração líquido/líquido.

ЭMesmo em presença de PCB (aroclor), a produção de metano nos reatores em batelada foi elevada $\left(3,8 \times 10^{-4} \mathrm{mmol} \mathrm{CH}_{4} / \mathrm{g} \mathrm{STV}\right)$. 
-Através da alta taxa de redução férrica (em média 90\%) pode-se inferir que o crescimento das bactérias redutoras de ferro também não foi alterado pela presença de PCB em forma de aroclor 1260.

PPor meio das análises de Biologia Molecular (PCR/DGGE) das amostras do ensaio em batelada e do reator RAHLF pode-se inferir que as amostras se afiliaram de acordo com a configuração do reator e tipo de PCB adicionado. 
"Não permitas que os problemas externos, inclusive os do próprio corpo, te inabilitem para o serviço da tua iluminação." 


\section{Sugestões Para Trabalhos Futuros}

Com base na experiência adquirida durante este trabalho, sugere-se:

- Testar qual método de extração é mais adequado para análise se PCB.

- Estudar a técnica de espectrometria de massa para determinação de PCB e seus possíveis intermediários da degradação anaeróbia, e assim, tentar estabelecer possível rota metabólica.

○ Utilizar maiores concentrações de aroclor em ensaio em batelada nas mesmas condições aplicadas no presente trabalho.

- Avaliar a importância de bactérias redutoras de ferro para a degradação de PCB. 


\section{REFERÊNCIA BIBLIOGRÁFICA}

ABNT (Brasil), Líquidos Isolantes Elétricos - Determinação do Teor de Bifenilas Policloradas; NBR 13882/97; São Paulo; 1997.

ABNT (Brasil); Acareis para Transformadores e capacitores; NBR 8371/94; São Paulo; 1994.

ABRAMOWICZ, D. A. Aerobic and anaerobic biodegradation of PCBs- A REVIEW. Critical Reviews in Biotechnology, v. 10, n. 3, p. 241-249, 1990.

ACHTNICH, C.; BAK, F.; CONRAD, R. Competition for electron donors among nitrate reducers, ferric iron reducers, sulfate reducers, and methanogens in anoxic paddy soil. Biology and Fertility of Soils, v. 19, n. 1, p. 65-72, 1995.

Agency for Toxic Substances and Disease Registry (ATSDR). Toxicological profile for polychlorinated biphenyls (PCBs); Atlanta, GA/U.S. Department of Health and Human Services, Public Health Service, 2000.

ALLEN, J. G.; BEUTEL, M. W.; CALL, D. R.; FISCHER, A. M. Effects of oxygenation on ammonia oxidation potential and microbial diversity in sediment from surface-flow wetland mesocosms. Bioresource Technology, v. 101, n. 4, p. 1389-1392, 2010.

ANGELIDAKI, I.; PETERSEN, S. P.; AHRING, B. K. Effects of Lipids on Thermophilic Anaerobic-Digestion and Reduction of Lipid Inhibition Upon Addition of Bentonite. Applied Microbioliology and Biotechnology, v. 33, n 4, p. 469-472, 1990.

APHA, AWWA \& WPCF. Standard methods for the examination of water and wastewater. 18 ed. Washington, D.C. American Public Health Association, p. 550-554, 1975.

BAEDECKER, M. J.; BACK, W. MODERN MARINE-SEDIMENTS AS A NATURAL ANALOG TO THE CHEMICALLY STRESSED ENVIRONMENT OF A LANDFILL. Journal of Hydrology, v. 43, n. 1-4, p. 393-414, 1979.

BAEDECKER, M. J.; COZZARELLI, I. M.; EGANHOUSE, R. P.; SIEGEL, D. I.; BENNETT, P. C. CRUDE-OIL IN A SHALLOW SAND AND GRAVEL AQUIFER .3. BIOGEOCHEMICAL REACTIONS AND MASSBALANCE MODELING IN ANOXIC GROUNDWATER. Applied Geochemistry, v. 8, n. 6, p. 569-586, 1993.

BAIRD, C. Química Ambiental. Tradução de Maria Angeles Lobo Recio e Luiz Carlos Marques Carrera. $2^{a}$ edição. Porto Alegre: Editora Bookman, 622 p, 2002. 
BAXTER, R. A.; GILBERT, P. E.; LIDGETT, R. A.; MAINPRIZE, J. H.; VODDEN, H. A. The degradation of polychlorinated biphenyls by micro-organisms. Science of The Total Environment, v. 4, n. 1, p. 53-61, 1975.

BEDARD, D. L., A Case Study for Microbial Biodegradation: Anaerobic Bacterial Reductive Dechlorination of Polychlorinated Biphenyls-From Sediment to Defined Medium; Annu. Rev. Microbiol.,v. 62, p. 253-270, 2008.

BEDARD, D. L.; RITALAHTI, K. M.; LÖFFLER, F. E. The Dehalococcoides Population in Sediment-Free Mixed Cultures Metabolically Dechlorinates the Commercial Polychlorinated Biphenyl Mixture Aroclor 1260. Applied and Environmental Microbiology, v. 73, n. 8, p. 2513-2521, 2007.

BODEGOM, P. M. V. e STAMS, A. J. M. Effects of alternative electron acceptors and temperature on methanogenesis in rice paddy soils. Chemosphere, v. 39, n. 2, p. 167-182, 1999.

BOGA, H. I.; LUDWIG, W.; BRUNE, A. Sporomusa aerivorans sp. nov., an oxygenreducing homoacetogenic bacterium from the gut of a soil-feeding termite. International Journal of Systematic and Evolutionary Microbiology, v. 53, n. 5, p. 1397-1404, 2003.

BOND, D. R. e LOVLEY, D. R. Reduction of Fe(III) oxide by methanogens in the presence and absence of extracellular quinones. Environmental Microbiology, v. 4, n. 2, p. 115-124, 2002.

BOONE, D. R.; LIU Y.; ZHAO Z. J.; BALKWILL D. L. Bacillus infernus sp. nov., an $\mathrm{Fe}(\mathrm{III})-$ and $\mathrm{Mn}(\mathrm{IV})$-reducing anaerobe from the deep terrestrial subsurface. Internat. J. Syst. Bacteriol., v. 45, n. 3, p. 441-448, 1995.

BORJA, J.; TALEON, D. M.; AURESENIA, J.; GALLARDO, S. Polychlorinated biphenyls and their biodegradation. Process Biochemistry, v. 40, n. 6, p. 1999-2013, 2005.

BOYLE, A. W.; SILVIN, C. J.; HASSETT, J. P.; NAKAS, J. P.; TANENBAUM, S. W. Bacterial PCB biodegradation. Biodegradation, v. 3, n. 2, p. 285-298, 1992.

BREZNAK, J. A.; SWITZER, J. M.; SEITZ, H. J. Sporomusa termitida sp. nov., an $\mathrm{H} 2 / \mathrm{CO} 2$-utilizing acetogen isolated from termites Archives of Microbiology, v. 150, n. 3, p. 282-288, 1988.

BRYANT, D. A. e FRIGAARD, N. U. Prokaryotic photosynthesis and phototrophy illuminated. Trends in Microbiology, v. 14, n. 11, p. 488-496, 2006.

CERVANTES, F. J.; BOK, F. A. M. D.; DUONG-DAC, T.; STAMS, A. J. M.; LETTINGA, G.; FIELD, J. A. Reduction of humic substances by halorespiring, sulphate-reducing and methanogenic microorganisms. Environmental Microbiology, v. 4, n. 1, p. 51-57, 2002. 
CHAMP, D. R.; GULENS, J.; JACKSON, R. E. OXIDATION-REDUCTION SEQUENCES IN GROUND-WATER FLOW SYSTEMS. Canadian Journal of Earth Sciences, v. 16, n. 1, p. 12-23, 1979.

CHEN, S.; IMACHI, H.; SEKIGUCHI, Y.; HANADA, S.; KAMAGATA, Y.; OHASHI, A.; HARADA, H. Isolation of a novel anaerobic ethanoloxidizing bacterium from an anaerobic digested sludge - Não publicado

CHENG, L. e LU, Y. Molecular characterization of hexadecane-degrading methanogenic consortium - Não publicado

CORNISH SHARTAU, S. L.; YURKIW, M.; LIN, S.; GRIGORYAN, A. A.; LAMBO, A.; PARK, H.-S.; LOMANS, B. P.; VAN DER BIEZEN, E.; JETTEN, M. S. M.; VOORDOUW, G. Ammonium Concentrations in Produced Waters from a Mesothermic Oil Field Subjected to Nitrate Injection Decrease through Formation of Denitrifying Biomass and Anammox Activity. Applied and Environmental Microbiology, v. 76, n. 15, p. 4977-4987, 2010.

CORREA, R. C.. Degradação de bifenila policlorada e caracterização da comunidade microbiana de reator anaeróbio com biofilme. 2011. 172 p. Tese (Doutorado em Engenharia Hidráulica e Saneamento) - Escola de Engenharia de São Carlos, Universidade de São Paulo, São Carlos, São Paulo, 2011.

CUTTER, L.; SOWERS, K. R.; MAY, H. D. Microbial dechlorination of 2,3,5,6tetrachlorobiphenyl under anaerobic conditions in the absence of soil or sediment. Applied and Environmental Microbiology, v. 64, n. 8, p. 29662969, 1998.

DALEVI, D.; HUGENHOLTZ, P.; BLACKALL, L. L. A multiple-outgroup approach to resolving division-level phylogenetic relationships using 16S rDNA data. International Journal of Systematic and Evolutionary Microbiology, v. 51, n. 2, p. 385-91, 2001.

D'ANGELO, E. M. e NUNEZ, A. E. Phylogenetic Characterization of Polychlorinated Biphenyl Dechlorinating Consortia Under Different Anaerobic Treatments of Ohio River Sediments - Não publicado

D'ANGELO, E. M. e NUNEZ, A. E. Effect of environmental conditions on polychlorinated biphenyl transformations and bacterial communities in a river sediment. Journal of Soils and Sediments, v. 10, n. 6, p. 1186-1199, 2010.

DAS, R.; SAR, P.; KAZY, S. K. Microbial diversity in petroleum hydrocarbon contaminated sludge sample- Não publicado

DE VOS, P. e DE LEY, J. Intra- and intergeneric similarities of Pseudomonas and Xanrhomonas ribosomal ribonucleic acid cistrons. International Journal of Systemutic Bacteriology. v. 33, p. 487-509, 1983. 
DE VOS, P.; GOOR, M.; GILLIS, M.; DE LEY, J. Ribosomal ribonucleic acid cistron similarities of phytopathogenic Pseudomonas species. International Journal of Systematic Bacteriology. v. 35, p. 169-184, 1935.

DEHNING, I.; STIEB, M.; SCHINK, B. Sporomusa malonica sp. nov., a homoacetogenic bacterium growing by decarboxylation of malonate or succinate Archives of Microbiology, v. 151, n. 5, p. 421-426, 1989.

DELFORNO, T. P. Caracterização microbiana e remoção do alquilbenzeno linear sulfonado em reator EGSB. 123 p. Dissertação (Mestrado em Engenharia Hidráulica e Saneamento) - Escola de Engenharia de São Carlos, Universidade de São Paulo, São Carlos, São Paulo, 2011.

DELFORNO, T. P.; OKADA, D. Y.; POLIZEL, J.; SAKAMOTO, I. K.; VARESCHE, M. B. A. Microbial characterization and removal of anionic surfactant in an expanded granular sludge bed reactor. Bioresource Technology, v. 107, p. 103-109, 2012.

DIPIPPO, J. L.; NESBO, C. L.; DAHLE, H.; DOOLITTLE, W. F.; BIRKLAND, N. K.; NOLL, K. M. Kosmotoga olearia gen. nov., sp nov., a thermophilic, anaerobic heterotroph isolated from an oil production fluid. International Journal of Systematic and Evolutionary Microbiology, v. 59, p. 2991-3000, 2009.

DOBBINS, D. C. Biodegradation of pollutants. In: Encyclopedia of environmental biology, Academic Press Inc., n. 1, p. 128, 1995.

DOLLHOPF, S. L.; HASHSHAM, S. A.; DAZZO, F. B.; HICKEY, R. F.; CRIDDLE, C. S.; TIEDJE, J. M. The impact of fermentative organisms on carbon flow in methanogenic systems under constant low-substrate conditions. Applied Microbiology and Biotechnology, v. 56, n. 3-4, p. 531-538, 2001.

DUHAMEL, M. e EDWARDS, E. A. Microbial composition of chlorinated ethenedegrading cultures dominated by Dehalococcoides. Fems Microbiology Ecology, v. 58, n. 3, p. 538-549, 2006.

ELETROPAULO; Ficha de Instrução Para Transformadores e Capacitores; jun; 1994.

FAGERVOLD, S. K.; WATTS, J. E. M.; MAY, H. D.; SOWERS, K. R. Sequential Reductive Dechlorination of meta-Chlorinated Polychlorinated Biphenyl Congeners in Sediment Microcosms by Two Different Chloroflexi Phylotypes. Applied and Environmental Microbiology, v. 71, p. 8085-8090, 2005.

FAGERVOLD, S. K.; MAY, H. D.; SOWERS, K. R. Microbial reductive dechlorination of aroclor 1260 in Baltimore Harbor sediment microcosms is catalyzed by three phylotypes within the phylum Chloroflexi. Applied and Environmental Microbiology, v. 73, n. 9, p. 3009-3018, 2007. 
FLORENTINO, H. O.; BISCARO, A. F. V.; PASSOS, J. R. S. Funções sigmoidais aplicadas na determinação da atividade metanogênica específica - AME. Rev. Bras. Biom., v.28, n.1 , p. 141-150, 2010.

FREDRICKSON J. K. e GORBY Y. A. Environmental processes mediated by ironreducing bacteria. Curr Opin Biotechnol, v. 7, p. 287-294, 1996.

FURUKAMA, K. Modification of PCBs by Bacteria and Other Microorganisms, In PCBs and the Environment, ed. JS Waid. CRC Press, Boca Raton, Florida, USA, 5687 p., 1986.

GANESAN, A.; CHAUSSONNERIE, S.; TARRADE, A.; DAUGA, C.; BOUCHEZ, T.; PELLETIER, E.; LE PASLIER, D.; SGHIR, A. Cloacibacillus evryensis gen. nov., sp. nov., a novel asaccharolytic, mesophilic, amino-aciddegrading bacterium within the phylum 'Synergistetes', isolated from an anaerobic sludge digester. International Journal of Systematic and Evolutionary Microbiology, v. 58, n. 9, p. 2003-2012, 2008.

GARRITY, G.M. e HOLT, J.G. In: D.R. Boone e R.W. Castenholz (eds.), Bergey's Manual of Systematic Bacteriology, 4 v., 2nd ed., Springer-Verlag, New York, 2001.

GHIORSE, W. C. BIOLOGY OF IRON-DEPOSITING AND MANGANESEDEPOSITING BACTERIA. Annual Review of Microbiology, v. 38, 1984, p. 515-550, 1984.

GHIORSE, W.C. e EHRLICH, H.L., 1992. Microbial biomineralization of iron and manganese. In: Skinner, H.C.W., Fitzpatrick, R.W. Eds., Biomineralization. Processes of Iron and Manganese. Catena Verlag, CremLingen, p. 75-99.

GÖßNER, A. S.; KÜSEL, K.; SCHULZ, D.; TRENZ, S.; ACKER, G.; LOVELL, C. R.; DRAKE, H. L. Trophic interaction of the aerotolerant anaerobe Clostridium intestinale and the acetogen Sporomusa rhizae sp. nov. isolated from roots of the black needlerush Juncus roemerianus. Microbiology, v. 152, n. 4, p. 1209-1219, 2006.

GÖßNER, A.; DANIEL, S. L.; DRAKE, H. L. Acetogenesis coupled to the oxidation of aromatic aldehyde groups. Archives of Microbiology, v. 161, n. 2, p. 126$131,1994$.

GRIFFITHS R.I.; WHITELEY A.S.; O'DONNELL A.G. Rapid Method for coextration of DNA from natural environments for analysis of ribosomal DNA and rRNA-based microbil community composition. Applied and Environmental Microbiology, v. 66, p. 5488-5491, 2000.

GRISHCHENKOV, V. G.; SLEPEN'KIN, A. V.; BORONIN, A. M. Anaerobic Degradation of Biphenyl by the Facultative Anaerobic Strain Citrobacter freundii BS2211. Applied Biochemistry and Microbiology, v. 38, p. 125 128, 2002. 
HANSON, R. S. e HANSON, T. E. Methanotrophic bacteria. Microbiological Reviews, v. 60, n. 2, p. 439-71, 1996.

HIRASAWA, J. S. Avaliação da metanogênese e sulfetogênese na presença de oxigênio, sob diferentes relações etanol/sulfato, utilizando técnicas de biologia molecular. 2007. Tese (Doutorado em Hidráulica e Saneamento) Escola de Engenharia de São Carlos, Universidade de São Paulo, São Carlos, 2007.

HIRATA, Y. S. Características e Interações microbianas nos processos de tratamento biológico aeróbio e anaeróbio. In: III Curso de Tratamento Biológico de Resíduos, Florianópolis, Brasil, 1997.

HONDA, T.; KITAMURA, K.; FUJITA, T.; TONOUCHI, A. A Synergistaceae bacterium isolated from rice field soil in Japan - Não publicado

HOU, L. H. e DUTTA, S. K. Phylogenetic characterization of several para- and metaPCB dechlorinating Clostridium species: 16s rDNA sequence analyses. Letters in Applied Microbiology, v. 30, n. 3, p. 238-243, 2000.

HULT, M. F. e SURVEY, G. Ground-water contamination by crude oil at the Bemidji, Minnesota, research site: U.S. Geological Survey toxic waste--ground-water contamination study. In: Toxic-Waste Technical Meeting, Tucson, Arizona, 1984.

HUTZINGER, O.; SAFE, S.; ZITKO, V. Chemistry of PCB's. Cleveland: CRC Press, $278 \mathrm{p}, 1974$.

Instrução Normativa SEMA/STC/CRS N. 1 de 10 de junho de 1983.

JEANTHON, C.; REYSENBACH, A. L.; LHARIDON, S.; GAMBACORTA, A.; PACE, N. R.; GLENAT, P.; PRIEUR, D. THERMOTOGA SUBTERRANEA SP-NOV, A NEW THERMOPHILIC BACTERIUM ISOLATED FROM A CONTINENTAL OIL-RESERVOIR. Archives of Microbiology, v. 164, n. 2, p. 91-97, 1995.

JUMAS-BILAK, E.; ROUDIÈRE, L.; MARCHANDIN, H. Description of 'Synergistetes' phyl. nov. and emended description of the phylum 'Deferribacteres' and of the family Syntrophomonadaceae, phylum 'Firmicutes'. International Journal of Systematic and Evolutionary Microbiology, v. 59, n. 5, p. 1028-1035, 2009.

KAKSONEN, A. H.; PLUMB, J. J.; ROBERTSON, W. J.; FRANZMANN, P. D.; GIBSON, J. A. E.; PUHAKKA, J. A. Culturable diversity and community fatty acid profiling of sulfate-reducing fluidized-bed reactors treating acidic, metal-containing wastewater. Geomicrobiology Journal, v. 21, n. 7, p. 469480, 2004. 
KAPLEY, A. e PUROHIT, H. J. Uncultured bacterial diversity from activated biomass of common effluent treatment plant (CETP) treating nitro- and chloroaromatic residues under hypersaline conditions - Não publicado

KINNER, L. L.; MANAHAN, S. E.; LARSEN, D. W. Gasification of wastecontaminated soil by the ChemChar process. Journal of Enviromental Science and Health, v. 28, p. 697-727, 1993.

KO, F. C. e BAKER, J. E. Seasonal and annual loads of hydrophobic organic contaminants from the Susquehanna River basin to the Chesapeake Bay. Marine Pollution Bulletin, v. 48, n. 9-10, p. 840-851, 2004.

KONHAUSER, K. O. Diversity of bacterial iron mineralization. Earth-Science Reviews, v. 43, n. 3-4, p. 91-121, 1998.

KUDO, Y.; NAKAJIMA, T.; MIYAKI, T.; OYAIZU, H. Methanogen flora of paddy soils in Japan. FEMS Microbiology Ecology, v. 23, p. 39-48, 1997.

KUEVER, J.; RAINEY, F.; WIDDEL, F. Family I. Desulfuromonaceae fam. nov. (Desulfuromonadaceae corrig. Kuever et al. 2006). In: BRENNER, D. J.; KRIEG, N. R. et al (Ed.). Bergey's Manual of Systematic Bacteriology: Springer US, v.2, p.1004-1005, 2005.

KUHNER, C. H.; FRANK, C.; GRIEßZHAMMER, A.; SCHMITTROTH, M.; ACKER, G.; GÖßZNER, A.; DRAKE, H. L. Sporomusa silvacetica sp. nov., an Acetogenic Bacterium Isolated from Aggregated Forest Soil. International Journal of Systematic Bacteriology, v. 47, n. 2, p. 352-358, 1997.

LANE, D. J. 16S/23S rRNA sequencing. In: Stackebrandt E. e Goodfellow M. (eds) Nucleic Acid Techniques in Bacterial Systematics, Wiley, New York, p 115-175, 1991.

Lei Estadual 12.288 de 22 de fevereiro de 2006

LEISTER, D. L.; BAKER, J. E. ATMOSPHERIC DEPOSITION OF ORGANIC CONTAMINANTS TO THE CHESAPEAKE BAY. Atmospheric Environment, v. 28, n. 8, p. 1499-1520, 1994.

LOVLEY, D. R.; BAEDECKER, M. J.; LONERGAN, D. J.; COZZARELLI, I. M.; PHILLIPS, E. J. P.; SIEGEL, D. I. Oxidation of aromatic contaminants coupled to microbial iron reduction. Nature, v. 339 , n. 6222, p. 297-300, 1989.

LOVLEY, D. R. e GOODWIN, S. HYDROGEN CONCENTRATIONS AS AN INDICATOR OF THE PREDOMINANT TERMINAL ELECTRONACCEPTING REACTIONS IN AQUATIC SEDIMENTS. Geochimica Et Cosmochimica Acta, v. 52, n. 12, p. 2993-3003, 1988. 
LOVLEY, D. R. e LONERGAN, D. J. ANAEROBIC OXIDATION OF TOLUENE, PHENOL, AND PARA-CRESOL BY THE DISSIMILATORY IRONREDUCING ORGANISM, GS-15. Applied and Environmental Microbiology, v. 56, n. 6, p. 1858-1864, 1990.

LOVLEY, D. R. e PHILLIPS, E. J. P. COMPETITIVE MECHANISMS FOR INHIBITION OF SULFATE REDUCTION AND METHANE PRODUCTION IN THE ZONE OF FERRIC IRON REDUCTION IN SEDIMENTS. Applied and Environmental Microbiology, v. 53, n. 11, p. 2636-2641, 1987.

MANICKAM, N.; PATHAK, A.; SAINI, H. S.; MAYILRAJ, S.; SHANKER, R. Metabolic profiles and phylogenetic diversity of microbial communities from chlorinated pesticides contaminated sites of different geographical habitats of India. Journal of Applied Microbiology, v. 109, n. 4, p. 14581468, 2010.

MARCHANDIN, H.; TEYSSIER, C.; CAMPOS, J.; JEAN-PIERRE, H.; ROGER, F.; GAY, B.; CARLIER, J. P.; JUMAS-BILAK, E. Negativicoccus succinicivorans gen. nov., sp nov., isolated from human clinical samples, emended description of the family Veillonellaceae and description of Negativicutes classis nov., Selenomonadales ord. nov and Acidaminococcaceae fam. nov in the bacterial phylum Firmicutes. International Journal of Systematic and Evolutionary Microbiology, v. 60, p. 1271-1279, 2010.

MASTER, E. R.; LAI, V. W. M.; KUIPERS, B.; CULLEN, W. R.; MOHN, W. W. Sequential anaerobic-aerobic treatment of soil contaminated with weathered Aroclor 1260. Environmental Science and Technology, v. 36, n. 1, p. 100103, 2002.

MAYMO-GATELL, X.; ANGUISH, T.; ZINDER, S. H. Reductive dechlorination of chlorinated ethenes and 1,2-dichloroethane by "Dehalococcoides ethenogenes" 195. Applied and Environmental Microbiology, v. 65, n. 7, p. 3108-3113, 1999.

MCCRADY, M. H. The numerical interpretation of fermentation-tube results. Journal of Infectious Diseases, v. 17, n. 1, p. 183-212, 1915.

MCELDOWNEY, S.; HARDMAN, D. J.; WAITE, S. Pollution: ecology and biotreatment. Ed. Longman Scientific \& Technical, Universidade de Michigan, 322 p, 1993.

MOE, W. M.; YAN, J.; NOBRE, M. F.; DA COSTA, M. S.; RAINEY, F. A. Dehalogenimonas lykanthroporepellens gen. nov., sp. nov., a reductively dehalogenating bacterium isolated from chlorinated solvent-contaminated groundwater. International Journal of Systematic and Evolutionary Microbiology, v. 59, n. 11, p. 2692-2697, 2009. 
MOHN, W. W. e TIEDJE, J. M. MICROBIAL REDUCTIVE DEHALOGENATION. Microbiological Reviews, v. 56, n. 3, p. 482-507, 1992.

MÖLLER, B.; OßMER, R.; HOWARD, B. H.; GOTTSCHALK, G.; HIPPE, H. Sporomusa, a new genus of gram-negative anaerobic bacteria including Sporomusa sphaeroides spec. nov. and Sporomusa ovata spec. nov. . Archives of Microbiology, v. 139, n. 4, p. 388-396, 1984.

MUYZER, G.; WAAL, E. C.; UITTERLINDEN, G. Profiling of Complex Microbial Populations by Denaturing Gradient Gel Electrophoresis Analysis of Polymerase Chain Reaction-Amplified Genes Coding for 16S RNAr. Applied and Environmental Microbiology, v. 59, p. 695-700, 1993.

NAYAK, S. S. e KALE, S. P. PCR and RFLP analysis of anaerobes of Nisargruna biogas plant - Não publicado

NEPOMNYASHAYA, Y.; SLOBODKINA, G.; KOLGANOVA, T.; BONCHOSMOLOVSKAYA, E.; NETRUSOV, A.; SLOBODKIN, A. Phylogenetic composition of enrichment cultures of thermophilic prokaryotes reducing poorly crystalline $\mathrm{Fe}(\mathrm{III})$ oxide with and without direct contact between the cells and mineral. Microbiology, v. 79, n. 5, p. 663-671, 2010.

NESBO, C. L.; KUMARASWAMY, R.; DLUTEK, M.; DOOLITTLE, W. F.; FOGHT, J. Searching for Mesophilic Thermotogales Bacteria: "Mesotogas" in the Wild. Applied and Environmental Microbiology, v. 76, n. 14, p. 4896-4900, 2010.

NIELSEN, H.; BRUNAK, S.; VON HEIJNE, G. Machine learning approaches for the prediction of signal peptides and other protein sorting signals. Protein Engineering., v. 12, p. 3-9, 1999.

ORMOND, J. G. P. Glossário de termos usados em atividades agropecuárias, florestais ciências ambientais. Rio de Janeiro: BNDES, 316 p., 2006.

PENTEADO, J. C. P. e VAZ, J. M. O legado das bifenilas policloradas (PCBs). Química Nova, v. 24, p. 390-398, 2001.

PETRIE, L.; NORTH, N. N.; DOLLHOPF, S. L.; BALKWILL, D. L.; KOSTKA, J. E. Enumeration and characterization of iron(III)-reducing microbial communities from acidic subsurface sediments contaminated with uranium(VI). Applied and Environmental Microbiology, v. 69, n. 12, p. 7467-7479, 2003.

PHAM, V. D.; HNATOW, L. L.; ZHANG, S. P.; FALLON, R. D.; JACKSON, S. C.; TOMB, J. F.; DELONG, E. F.; KEELER, S. J. Characterizing microbial diversity in production water from an Alaskan mesothermic petroleum reservoir with two independent molecular methods. Environmental Microbiology, v. 11, n. 1, p. 176-187, 2009. 
PIERRE E.R. e MARIO W.C. Isolation of Brachymonas petroleovorans CHX, a novel cyclohexane-degrading L-proteobacterium. FEMS Microbiol Lett., v. 227, p. 101-106, 2003.

QUENSEN III, J. F.; TIEDJE, J. M.; BOYD, S. A. Reductive Dechlorination of Polychlorinated Biphenyls by Anaerobic Microorganisms from sediments. Science, v. 242, 1988.

RANTAKOKKO, P.; KIVIRANTA, H.; RYLANDER, L.; RIGNELL-HYDBOM, A.; VARTIAINEN, T. A simple and fast liquid-liquid extraction method for the determination of 2,2 ',4,4 ',5,5 '-hexachlorobiphenyl (CB-153) and 1,1dichloro-2,2-bis(p-chlorophenyl)-ethylene (p,p '-DDE) from human serum for epidemiological studies on type 2 diabetes. Journal of Chromatography $A$, v. 1216, n. 6, p. 897-901, 2009.

Relatório da CETESB (Companhia De Tecnologia De Saneamento Ambiental) Sistema Estuarino de Santos e São Vicente - São Paulo, 142p, 2001.

Resolução CONAMA número 19 de 19 de setembro de 1994

RIVIERE， D.; DESVIGNES， V.; PELLETIER， E.; CHAUSSONNERIE， S.; GUERMAZI, S.; WEISSENBACH, J.; LI, T.; CAMACHO, P.; SGHIR, A. Towards the definition of a core of microorganisms involved in anaerobic digestion of sludge. Isme Journal, v. 3, n. 6, p. 700-714, 2009.

ROCKNE, K. J. e STRAND, S. E. Anaerobic Biodegradation of Naphthalene, Phenanthrene, and Biphenyl by a Denitrifying Enrichment Culture. Watter Research, v, 35, p. $291-299,2001$.

RODEN, E. E.; URRUTIA, M. M.; MANN, C. J. Bacterial reductive dissolution of crystalline Fe(III) oxide in continuous-flow column reactors. Applied and Environmental Microbiology, v. 66, n. 3, p. 1062-1065, 2000.

ROSENCRANTZ, D.; RAINEY, F. A.; JANSSEN, P. H. Culturable populations of Sporomusa spp. and Desulfovibrio spp. in the anoxic bulk soil of flooded rice microcosms. Applied and Environmental Microbiology, v. 65, n. 8, p. 3526-3533, 1999.

ROSSETTI, S.; BLACKALL, L. L.; MAJONE, M.; HUGENHOLTZ, P.; PLUMB, J. J.; TANDOI, V. Kinetic and phylogenetic characterization of an anaerobic dechlorinating microbial community. Microbiology-Sgm, v. 149, p. 459469, 2003.

ROUVIERE, P. E. e CHEN, M. W. Isolation of Brachymonas petroleovorans CHX, a novel cyclohexane-degrading beta-proteobacterium. Fems Microbiology Letters, v. 227, n. 1, p. 101-106, 2003.

ROWE, A. R.; LAZAR, B. J.; MORRIS, R. M.; RICHARDSON, R. E. Characterization of the Community Structure of a Dechlorinating Mixed Culture and Comparisons of Gene Expression in Planktonic and Biofloc-Associated 
"Dehalococcoides" and Methanospirillum Species. Applied and Environmental Microbiology, v. 74, n. 21, p. 6709-6719, 2008.

SAFE, S. H. POLYCHLORINATED-BIPHENYLS (PCBS) - ENVIRONMENTALIMPACT, BIOCHEMICAL AND TOXIC RESPONSES, AND IMPLICATIONS FOR RISK ASSESSMENT. Critical Reviews in Toxicology, v. 24, n. 2, p. 87-149, 1994.

SAITOU, N. e NEI, M., The neighbor-joining method: a new method for reconstructing phylogenetic trees. Molecular Biology and Evolution, v. 4, p. 406-425, 1987.

SAKAMOTO, I. S. Comportamento do consórcio microbiano existente em um lodo granulado anaeróbio metanogênico submetido a adições crescentes de sulfato. Dissertação (Mestrado em Engenharia Hidráulica e Saneamento), Escola de Engenharia de São Carlos, Universidade de São Paulo, São Carlos, São Paulo, 1996.

SANZ, J. L. Métodos analíticos de biologia molecular em digestão anaeróbia, In: VII Taller sobre Digestão Anaeróbia, Mérida, México, 2002

SHIBAMOTO, T. Chromatographic Analysis of Environmental and Food Toxicants; Chromatographic Science Series, v. 77, CRC Press/New York, 1998.

SHIGEMATSU, T.; ERA, S.; MIZUNO, Y.; NINOMIYA, K.; KAMEGAWA, Y.; MORIMURA, S.; KIDA, K. Microbial community of a mesophilic propionate-degrading methanogenic consortium in chemostat cultivation analyzed based on $16 \mathrm{~S}$ rRNA and acetate kinase genes. Applied Microbiology and Biotechnology, v. 72, n. 2, p. 401-415, 2006.

SIFFERT, C. L'effet de la lumière sur la dissolution des oxydes de fer(III) dans les milieux aqueux, Ph.D., ETH-Zurich, Switzerland, 1989 apud VIOLLIER, E.; INGLETT, P. W.; HUNTER, K.; ROYCHOUDHURY, A. N.; VAN CAPPELlEN, P. The ferrozine method revisited: $\mathrm{Fe}(\mathrm{II}) / \mathrm{Fe}(\mathrm{III})$ determination in natural waters. Applied Geochemistry, v. 15, n. 6, p. 785790, 2000.

STETTER, K. O. e GAAG, G. Reduction of molecular sulphur by methanogenic bacteria. Nature, v. 305, n. 5932, p. 309-311, 1983.

STOOKEY, L. L. FERROZINE - A NEW SPECTROPHOTOMETRIC REAGENT FOR IRON. Analytical Chemistry, v. 42, n. 7, p. 779-\&, 1970.

SUN, Y.; ZUO, J.; CUI, L.; DENG, Q.; DANG, Y. Diversity of microbes and potential exoelectrogenic bacteria on anode surface in microbial fuel cells. Journal of General and Applied Microbiology, v. 56, n. 1, p. 19-29, 2010.

SYLVESTRE, M., e M. SONDOSSI. Selection of enhanced polychlorinated biphenyldegrading bacterial strains for bioremediation: consideration of branching pathways. In: G. R. Chaudry (ed.), Biological degradation and 
bioremediation of toxic chemicals. Dioscorides Press, Portland, Oreg, p. 3373, 1994.

TAMAKI, H.; TANAKA, Y.; MATSUZAWA, H.; MURAMATSU, M.; MENG, X.-Y.; HANADA, S.; MORI, K.; KAMAGATA, Y. Armatimonas rosea gen. nov., sp. nov., of a novel bacterial phylum, Armatimonadetes phyl. nov., formally called the candidate phylum OP10. International Journal of Systematic and Evolutionary Microbiology, v. 61, n. 6, p. 1442-1447, 2011.

TAMURA, K.; PEETERSON, D.; PETERSON, N.; STECHER, G.; NEI, M.; KUMAR, S. MEGA5: Molecular Evolutionary Genetics Analysis using Maximum Likehood, Evolutionary Distance and Maximum Parsimony Methods. Molecular Biology Evolution, Arizona State University, Tempe, Arizona, USA, 2011.

TIEDJE, J.M.; QUENSEN III, J.F.; CHEE-STANFORD, J.; SCHIMEL, J.P.; BOYD, S.A. Microbial reductive dechlorination of PCBs. Biodegradation, v. 3, p. 231-240, 1993.

U.S. EPA - United States Environmental Protection Agency. Polychlorinated Biphenyls (PCBs) Manufacturing, Processing, Distribution in Commerce and Use Prohibitions. Use in Electrical Equipment. Statement of Policy; Federal Register 40 CFR Part 761, v. 48, n. 35, 1983. Apud: Penteado, J. C. P. e Vaz, J. M. O legado das bifenilas policloradas (PCBs). Quim. Nova, v. 24, n. 3, p. 390-398, 2001.

URRUTIA, M. M.; RODEN, E. E.; FREDRICKSON, J. K.; ZACHARA, J. M. Microbial and surface chemistry controls on reduction of synthetic Fe(III) oxide minerals by the dissimilatory iron-reducing bacterium Shewanella alga. Geomicrobiology Journal, v. 15, n. 4, p. 269-291, 1998.

VAN BODEGOM, P. M.; SCHOLTEN, J. C. M.; STAMS, A. J. M. Direct inhibition of methanogenesis by ferric iron. Fems Microbiology Ecology, v. 49, n. 2, p. 261-268, 2004.

VARTOUKIAN, S. R.; PALMER, R. M.; WADE, W. G. Cultivation of a Synergistetes strain representing a previously uncultivated lineage. Environmental Microbiology, v. 12, n. 4, p. 916-928, 2010.

VAZOLLER, R.F., Avaliação do ecossistema microbiano de um biodigestor anaeróbio de fluxo ascendente e manta de lodo, operado com vinhaça sob condições termofílicas. Tese (Doutorado em Engenharia Hidráulica e Saneamento), Escola de Engenharia de São Carlos, Universidade de São Paulo, São Carlos, São Paulo, 1995.

VIEIRA, H. P.; NEVES, A. A.; DE QUEIROZ, M. Optimization and validation of liquid-liquid extraction with the low temperature partition technique (LLELTP) for pyrethroids in water and GC analysis. Química Nova, v. 30, n. 3, p. 535-540, 2007. 
VIOLLIER, E.; INGLETT, P. W.; HUNTER, K.; ROYCHOUDHURY, A. N.; VAN CAPPELLEN, P. The ferrozine method revisited: $\mathrm{Fe}(\mathrm{II}) / \mathrm{Fe}(\mathrm{III})$ determination in natural waters. Applied Geochemistry, v. 15, n. 6, p. 785790, 2000.

WATTS, J. E. M.; WU, Q. Z.; SCHREIER, S. B.; MAY, H. D.; SOWERS, K. R. Comparative analysis of polychlorinated biphenyl-dechlorinating communities in enrichment cultures using three different molecular screening techniques. Environmental Microbiology, v. 3, n. 11, p. 710-719, 2001.

WILLEMS, A.; DE LEY, J.; GILLIS, M.; KERSTERS, K. NOTES: Comamonadaceae, a New Family Encompassing the Acidovorans rRNA Complex, Including Variovorax paradoxus gen. nov., comb. nov., for Alcaligenes paradoxus (Davis 1969). International Journal of Systematic Bacteriology, v. 41, n. 3, p. 445-450, 1991.

WINDERL, C.; ANNESER, B.; GRIEBLER, C.; MECKENSTOCK, R. U.; LUEDERS, T. Depth-resolved quantification of anaerobic toluene degraders and aquifer microbial community patterns in distinct redox zones of a tar oil contaminant plume. Applied and Environmental Microbiology, v. 74, n. 3, p. 792-801, 2008.

WOLLIN, E. A.; WOLLIN, M.J.; WOLFE, R.S. Formation of Methane by Bacterial Extracts. The Journal of Biological Chemistry, v. 238, p. 8, 1963.

WU, Q.; SOWERS, K. R.; WATTS, J. E. M.; MAY, H. D. Identification of a Bacterium That Specifically Catalyzes the Reductive Dechlorination of Polychlorinated Biphenyls with Doubly Flanked Chlorines. Applied and Environmental Microbiology, v. 68, p. 807-812, 2002.

WU, Q. Z.; SOWERS, K. R.; MAY, H. D. Establishment of a polychlorinated biphenyldechlorinating microbial consortium, specific for doubly flanked chlorines, in a defined, sediment-free medium. Applied and Environmental Microbiology, v. 66, n. 1, p. 49-53, 2000.

YOUNG, J. C. e TABAK, H. H. Multilevel protocol for assessing the fate and effect of toxic organic chemicals in anaerobic treatment processes. Water Environment Research, v. 65, n. 5, p. 34 - 45, 1993. 


\section{ANEXO}

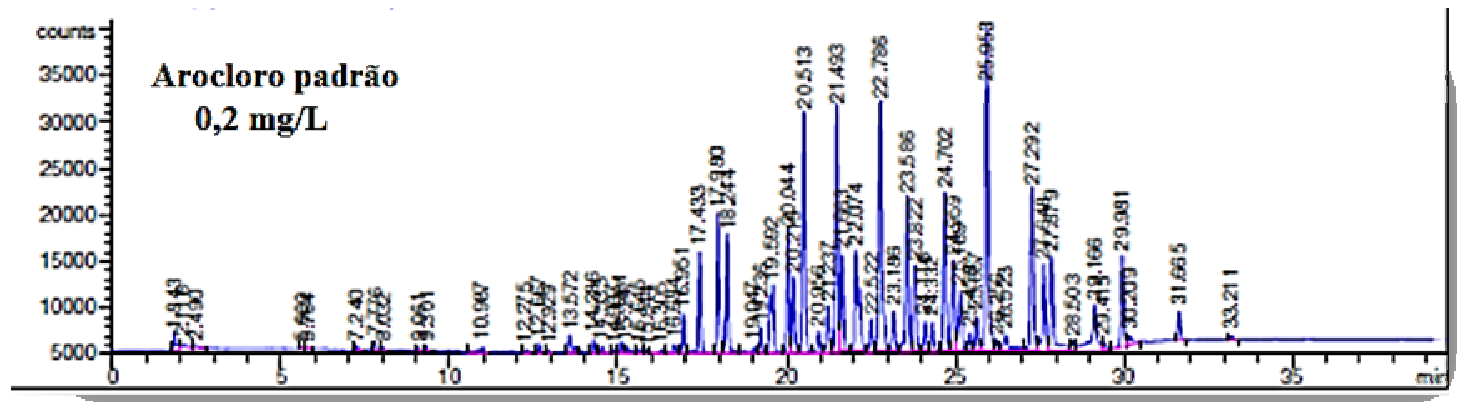

Figura 9-1. Cromatograma das áreas em função do tempo de retenção do aroclor 1260.

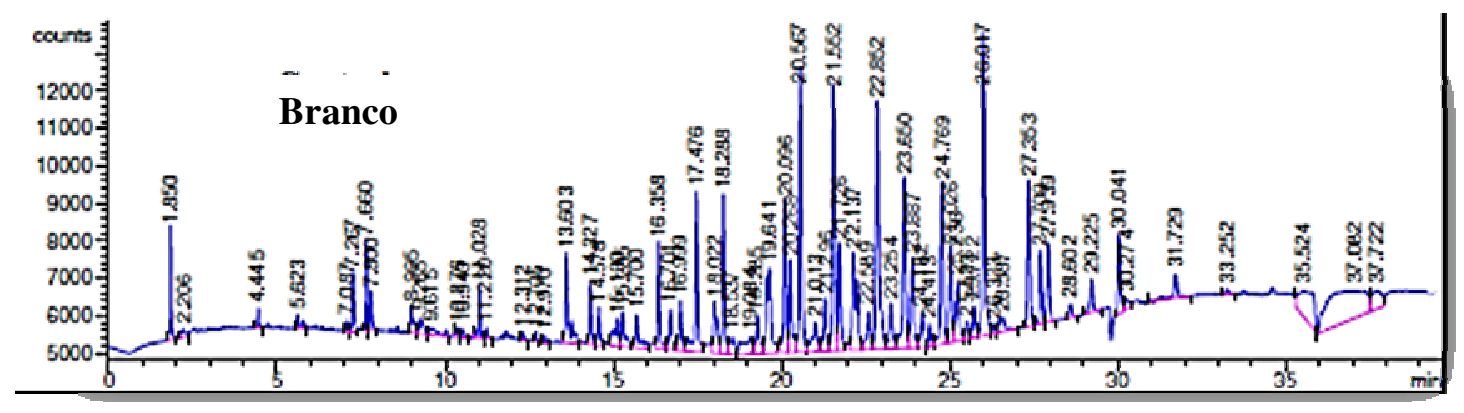

Figura 9-2. Cromatograma das áreas em função do tempo de retenção do reator Branco sem biomassa com meio Angelidaki e aroclor 1260.

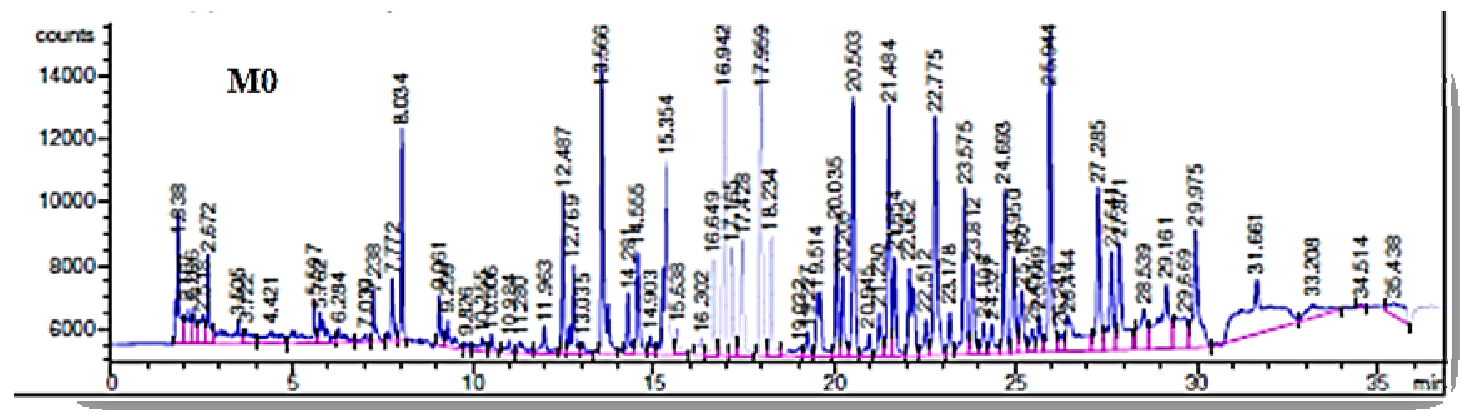

Figura 9-3. Cromatograma das áreas em função do tempo de retenção do controle em condição metanogênica (M0), na presença de meio ANgelidaki e Aroclor 1260 e biomassa inativada. 


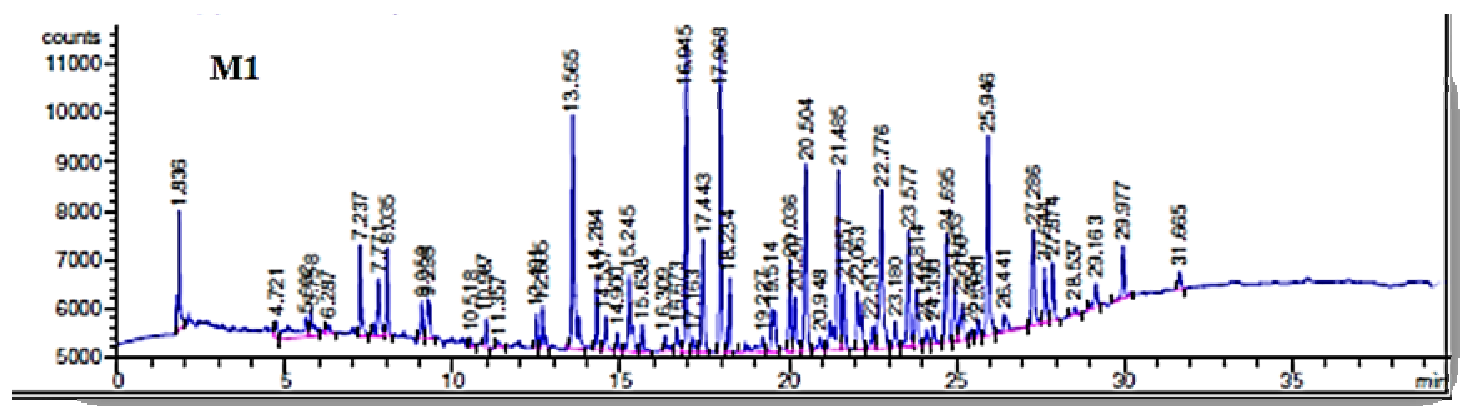

Figura 9-4. Cromatograma das áreas em função do tempo de retenção do reator em condição metanogênica (M1), na presença de meio Angelidaki e Aroclor 1260 e biomassa.

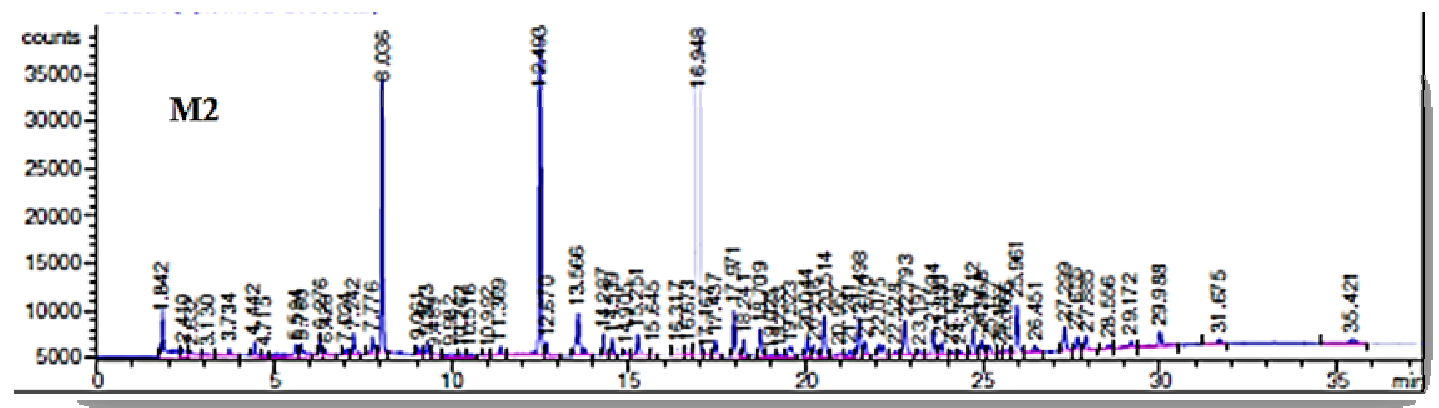

Figura 9-5. Cromatograma das áreas em função do tempo de retenção do reator em condição metanogênica (M2), na presença de meio Angelidaki e Aroclor 1260 e biomassa.

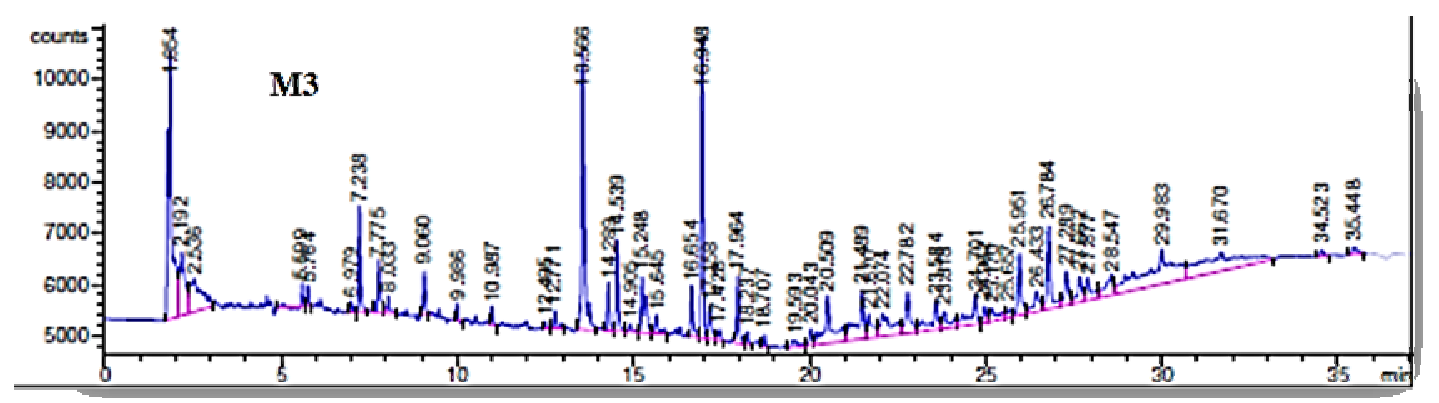

Figura 9-6. Cromatograma das áreas em função do tempo de retenção do reator em condição metanogênica (M3), na presença de meio Angelidaki e Aroclor 1260 e biomassa. 


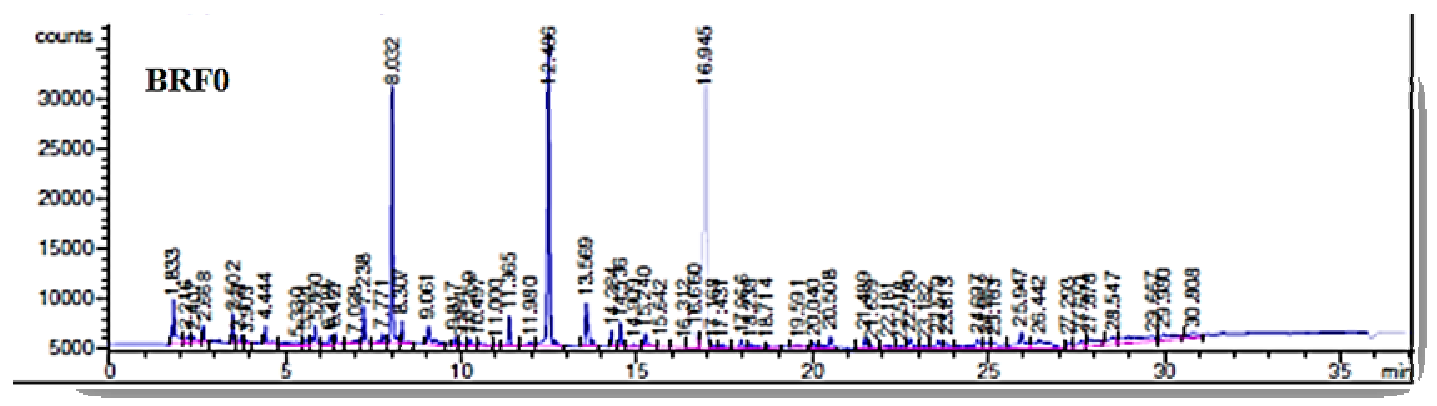

Figura 9-7. Cromatograma das áreas em função do tempo de retenção do controle em condição redutora de ferro (BRF0), na presença de meio Angelidaki e Aroclor 1260 e biomassa inativada.

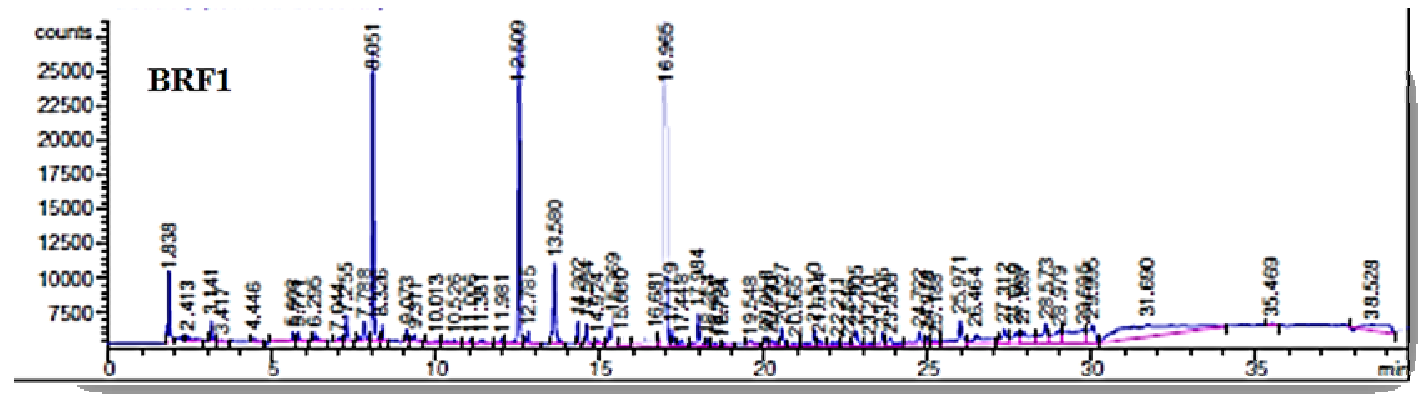

Figura 9-8. Cromatograma das áreas em função do tempo de retenção do reator em condição redutora de ferro (BRF1), na presença de meio Angelidaki e Aroclor 1260 e biomassa.

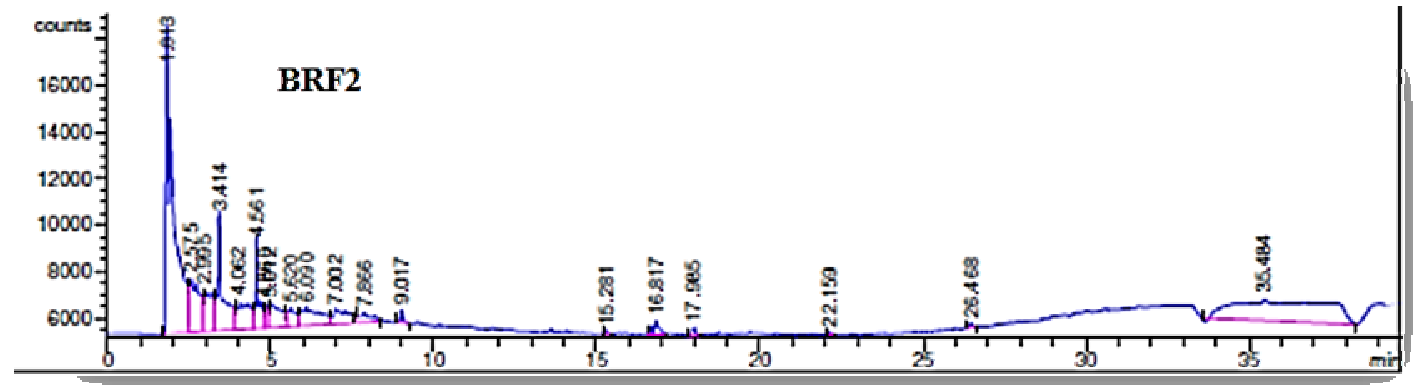

Figura 9-9. Cromatograma das áreas em função do tempo de retenção do reator em condição redutora de ferro (BRF2), na presença de meio Angelidaki e Aroclor 1260 e biomassa. 


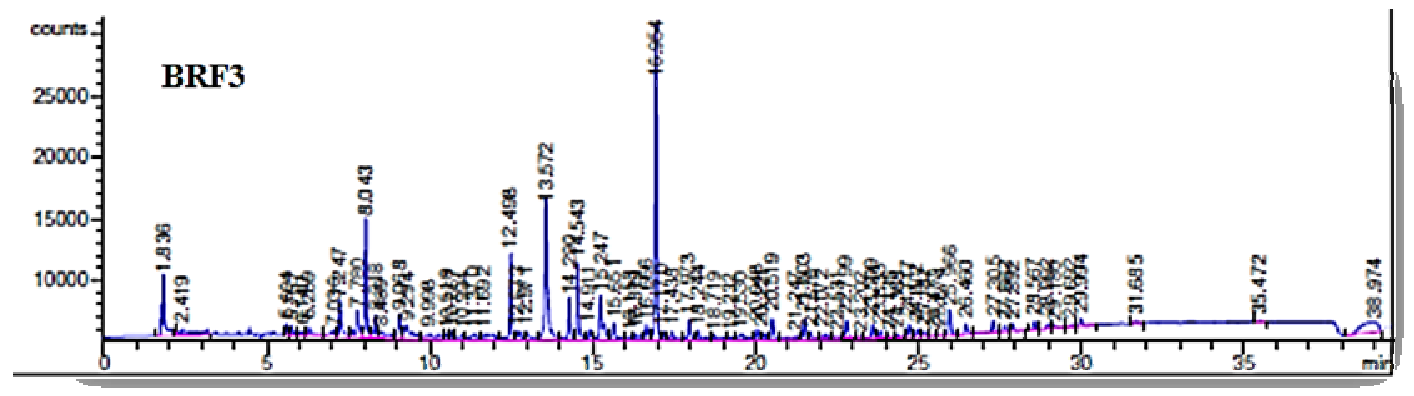

Figura 9-10. Cromatograma das áreas em função do tempo de retenção do reator em condição redutora de ferro (BRF3), na presença de meio Angelidaki e Aroclor 1260 e biomassa. 